MAX JOEL MUCHA FRANCO

APLICAÇÃO DA METODOLOGIA DE APPCC - ANÁLISE DE PERIGOS E PONTOS CRÍTICOS DE CONTROLE - COMO FERRAMENTA PARA REÚSO DE ÁGUA NA INDÚSTRIA: MODELO PARA INDÚSTRIA DE AROMAS E ESSÊNCIAS

Dissertação apresentada à Escola Politécnica da Universidade de São Paulo para obtenção do título de Mestre em Engenharia 


\section{APLICAÇÃO DA METODOLOGIA DE APPCC - ANÁLISE DE PERIGOS E PONTOS CRÍTICOS DE CONTROLE - COMO FERRAMENTA PARA REÚSO DE ÁGUA NA INDÚSTRIA: MODELO PARA INDÚSTRIA DE AROMAS E ESSÊNCIAS}

Dissertação apresentada à Escola Politécnica da Universidade de São Paulo para obtenção do título de Mestre em Engenharia

Área de concentração:

Engenharia Hidráulica e Sanitária

Orientador:

Prof. Doutor. José Carlos Mierzwa 
Este exemplar foi revisado e alterado em relação à versão original, sob responsabilidade única do autor e com a anuência de seu orientador.

São Paulo, 24 de Maio de 2007.

Assinatura do autor:

Assinatura do orientador

FICHA CATALOGRÁFICA

Franco, Max Joel Mucha

Aplicação da metodologia de APPCC - análise de pontos criticos de controle - como ferramenta para reúso de água na

indústria: modelo para indústria de aromas e essências / M.J.M.

Franco. -- São Paulo, 2007.

$118 \mathrm{p}$.

Dissertação (Mestrado) - Escola Politécnica da Universidade de São Paulo. Departamento de Engenharia Hidráulica e Sanitária.

1.Reuso de água 2.Administração da qualidade 3.Indústria de alimentos 4.Aditivos alimentares 5.Aromatizantes I.Universidade de São Paulo. Escola Politécnica. Departamento de Engenharia Hidráulica e Sanitária Il.t. 


\section{DEDICATÓRIA}

Aos meus pais Felipe e Paulina, e minhas irmãs Mariel, Delcy, e Enith, que sempre me estimularam em busca pelo conbecimento, fornecendo todo o apoio necessário para que meus sonbos pudessem ser realizados. 


\section{AGRADECIMENTOS}

Ao Prof. Dr. José Carlos Mierzwa pela sua orientação segura, dedicação, paciência, compreensão e incentivos constantes ao longo desses anos de convivência, mas principalmente pela sua amizade.

Ao Prof. Dr. Ivanildo Hespanhol pelo apoio e incentivo na minha formação na temática de Conservação e Reúso de Água

Aos demais professores da pós-graduação, pela competência e seriedade na condução de suas atividades.

A empresa GIVAUDAN do Brasil, que me proporcionou a oportunidade da divulgação dos dados deste estudo de caso.

Ao CAPES - Coordenação de Aperfeiçoamento de Pessoal de Nível Superior -, pela concessão da bolsa de estudos no último ano do mestrado, que me proporcionaram apoio financeiro para a realização desta pesquisa.

Aos amigos do CIRRA - Centro Internacional de Referência em Reúso de Água -, Alexandra, Simone, Rodrigo, Luana, Luciana, Mauricio, Alexandre, Camilo, Fabio, Ricardo, pelo carinho, atenção e dedicação.

Aos amigos da pós-graduação, pela amizade e convívio durante esse período, mesmo com dificuldades de tempo em função do trabalho profissional, souberam auxiliar uns aos outros por meio da troca de idéias e sugestões para a realização deste trabalho.

Aos meus amigos e parentes, mais próximos ou distantes, de quem não citarei nomes para não cometer injustiças ao esquecer algum de vocês, que participaram do meu dia-a-dia e que, direta ou indiretamente me toleraram e ajudaram a atingir o objetivo de concluir este trabalho. 


\section{RESUMO}

Uma das maiores preocupações da indústria de alimento é o grande consumo de água nos seus processos produtivos. A conservação e reúso da água é hoje uma necessidade real e crescente. Esta dissertação expõe conceitos sobre uso racional e reúso de água na indústria de aditivos alimentares, e sistemas de gestão da qualidade na indústria de alimentos. O objetivo principal deste trabalho foi desenvolver uma descrição da aplicação do sistema APPCC - Análise de Perigos e Pontos Críticos de Controle, como ferramenta no reúso de águas para as indústrias de alimentos, utilizando-se como estudo de caso uma indústria do setor de aromas e essências, fundamentado nos princípios da Gestão da Qualidade Total. Neste estudo são apresentados dados técnicos obtidos em visitas realizadas à empresa Givaudan, localizado na cidade de São Paulo, Brasil. Foi feita uma análise dos principais processos produtivos, para a identificação da demanda de água e, consequentemente, das áreas com maior potencial para a aplicação de alternativas para reúso da água. Determinou-se que os maiores consumos de água estão na produção de aromas e fragrâncias, referindo-se ao processo de lavagem de equipamentos e utensílios nas áreas de secagem de emulsões e tanques móveis. Recomenda-se tratar o efluente da operação de lavagem, posteriormente essa água tratada deve ser levada a um tanque de armazenamento para ser reusada internamente nos primeiros estágios de lavagem e enxágüe dos secadores do tipo Spray Dry. A ferramenta APPCC vai garantir a qualidade físico-química e microbiológica da água. O tratamento para este efluente que contém alta concentração de sólidos dissolvidos é através de osmose reversa por ser um processo que vai permitir uma alta remoção dos sólidos dissolvidos, bactérias e vírus. Para reduzir o consumo de água na empresa se propor um reúso de água não potável externamente, implantando e instalando uma estação de tratamento biológico para adequar o efluente proveniente da área de lavagens dos tanques móveis, lavadores de gases, vasos sanitários, e bebedouros.

Palavras chaves: Reúso de águas, administração da qualidade, indústria de alimentos, aditivos alimentares, aromatizantes.. 


\section{ABSTRACT}

One of the major problems faced by the food industry is their enormous water consumption is their productive processes. Water conservation and reuse is a real and increasing necessity. This dissertation discusses rational use concepts, industrial water reuse, quality management systems in the condiment sector of the food industry. The main objective of this dissertation is to develop the concept of HACCP Hazard Analysis and Critical Control Point - as a tool for water reuse in food industries, using the Flavor and Essence of food industry as a case study for total quality management. Presented in this study are the technical data obtained from Givaudan, a food industry located in the city of São Paulo, Brazil. The analysis of the main productive processes was done in order to identify the water demand and consequently, identify the areas where water reuse alternatives have more chances of being implemented. The major water consuming sectors in the company are the flavor and fragrance, ones especially, with equipment washing operations and utensils used in drying of emulsions and mobile tanks. One sends regards to deal with the effluent one the operation of laundering, later this treated water must be taken to a tank of storage to be reused internally in the first periods of training of laundering and rinses of the driers of the type Spray Dry. Tool APPCC goes to guarantee the quality microbiological physicist-chemistry and of the water. The treatment for this effluent one that it contains high dissolved solid concentration is through reverse osmosis for being a process that goes to allow one high removal of dissolved solids, bacteria and virus. To reduce the water consumption in the company if to consider one reuse externally of not potable water, implanting is installing a station of biological treatment to adjust effluent the proceeding one from the area of launderings of the mobile, washing tanks of gases, sanitary vases, and watering place.

Key Words: Water reuse, quality management, food industry, food additives, flavors. 


\section{LISTA DE ILUSTRAÇÕES}

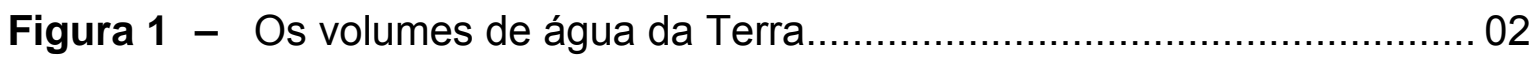

Figura 2 - Formas potenciais de reúso de água..............................................14

Figura 3 - Passos preliminares para a aplicação do reúso de água na

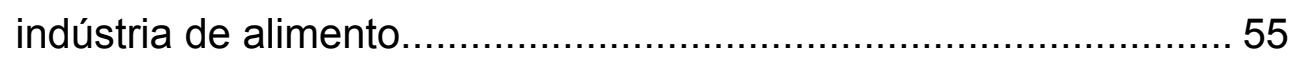

Figura 4 - Sete princípios do APPCC para a aplicação do reúso de água

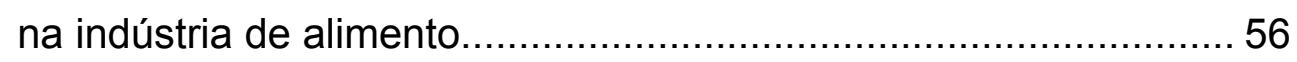

Figura 5 - Etapas para a implementação do sistema APPCC...........................57

Figura 6 - Sistema de secagem Spray Dryer..................................................74

Figura 7 - Abertura utilizada para a operação de lavagem do tanque de

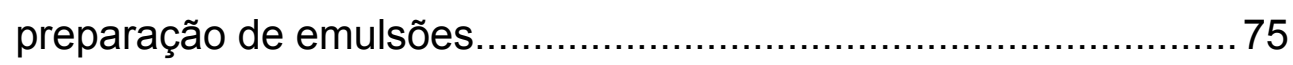

Figura 8 - Introdução das soluções de detergente, sanitizante e água filtrada no sistema de central CIP.............................................. 76

Figura 9 - Detalhe do tanque do sistema de limpeza e sanitização da

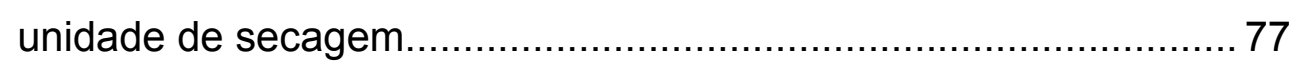

Figura 10 - Valores de turbidez dos enxágües em função do tempo de enxágüe das etapas de lavagem.

Figura 11 - Valores do pH em função do tempo de enxágüe das etapas de lavagem.

Figura 12 - Valores da condutividade em função do tempo de enxágüe das

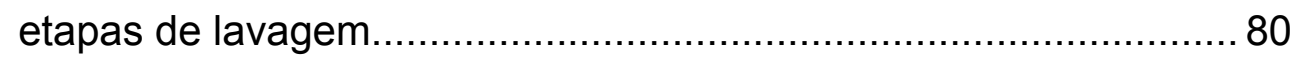

Figura 13 - Área de lavagem dos tanques móveis......................................... 81

Figura 14 - Operação de enxágüe do detergente dos tanques móveis............. 82

Figura 15 - Detalhe da lavagem de canecas sob a pia................................. 82

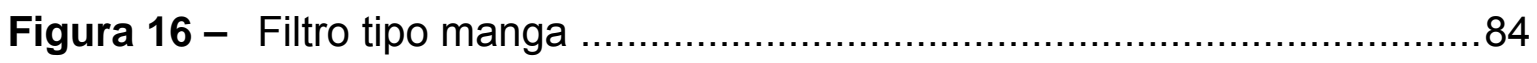

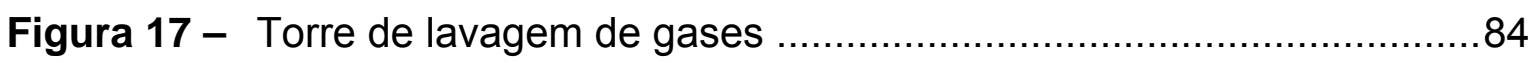

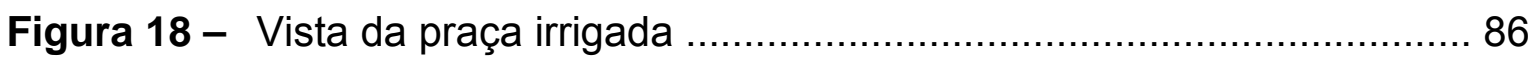

Figura 19 - Esquema do programa de reúso de água na área de lavagem.......87

Figura 20 - Diagrama de tratamento do efluente por osmose reversa................90

Figura 21 - Detecção do PCC no processo produtivo...................................... 91

Figura 22 - Fluxograma de lavagem do secador do tipo Spray Dryer................ 92

Figura 23 - Fluxograma de reúso para usos externos........................................95 


\section{LISTA DE TABELAS}

Tabela 1 - Exemplos dos processos de tratamentos para reúso de água na indústria de alimento................................................................. 20

Tabela 2 - Distribuição do consumo de água na indústria por atividades......... 23

Tabela 3 - Descrição dos tipos de tratamento para reúso e esgoto

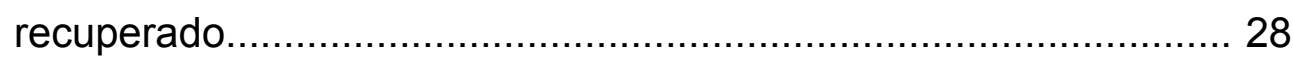

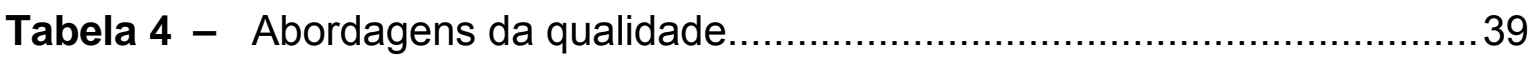

Tabela 5 - Descrição dos princípios do sistema de análise de perigos e pontos críticos de controle e seus respectivos objetivos............................ 54

Tabela 6 - Consumos e custos referentes ao fornecimento da Sabesp no 2006 .

Tabela 7 - Consumos e custos referentes ao fornecimento da Hidrogesp no 2006.

Tabela 8 - Analise de água para consumo humano na saída do poço tubular profundo no outubro do 2006. 69

Tabela 9 - Analise dos Inorgânicos e orgânicos da água na saída do poço tubular profundo no outubro do 2006.

Tabela 10 - Analise de agrotóxicos, desinfetantes e microbiológicos da água na saída do poço tubular profundo no outubro do 2006.

Tabela 11 - Analises físico-químicas e bacteriológicas da amostra de água da saída da ETA no outubro do 2006.

Tabela 12 - Tempos de cada etapa de lavagem do tanque Spray Dryer

Tabela 13 - Tempos de coletas e variáveis analisadas no primeiro enxágüe (rinse).

Tabela 14 - Tempos de coletas e variáveis analisadas no enxágüe do detergente.

Tabela 15 - Tempos de coletas e variáveis analisadas no enxágüe do sanitizante.

Tabela 16 - Estimativa do consumo de água por operação de lavagem do sistema de secagem de emulsões 
Tabela 17 - Valores lidos nos hidrômetros instalados nas lavagens dos tanques móveis no setor de aromas. 83

Tabela 18 - Valores lidos nos hidrômetros instalados nas lavagens dos tanques móveis no setor das fragrâncias.

Tabela 19 - Estimativa de consumo de água nos vasos sanitários. 85

Tabela 20 - Estimativa do consumo de água nas irrigações. .86

Tabela 21 - Estimativa do consumo de água aplicando tratamento por osmose reversa. 


\section{LISTA DE ABREVIATURAS E SIGLAS}

\begin{tabular}{|c|c|}
\hline ABNT & Associação Brasileira de Normas Técnicas \\
\hline APPCC & Análise de Perigos e Pontos Críticos de Controle \\
\hline BPF & Boas Práticas de Fabricação \\
\hline $\mathrm{BRC}$ & British Retail Consortium \\
\hline BVQI & Bureau Veritas Quality International \\
\hline CAC & Codex Alimentarius Commission \\
\hline CEP & Controle Estatístico do Processo \\
\hline CFDRA & Campden Food Drink Research Association \\
\hline CIP & Clean in Place \\
\hline CIRRA & Centro Internacional de Referência em Reúso de Água \\
\hline EUA & Estados Unidos da América \\
\hline EUREPGAP & Euro-Retailer Produce Working Group \\
\hline FAO & Food and Agriculture Organization \\
\hline FDA & Food and Drug Administration \\
\hline FMEA & Failure Mode and Effect Analysis \\
\hline FTA & Fault Tree Analysis \\
\hline GFSI & Global Food Safety Initiative \\
\hline GMP & Good Manufacturing Practices \\
\hline GQT & Gestão da Qualidade Total \\
\hline HACCP & Hazard Analysis and Critical Control Point \\
\hline ICMFS & International Commission on Microbiological Specifications for Foods \\
\hline INMETRO & Instituto Nacional de Metrologia, Normalização e Qualidade Industrial. \\
\hline ISO & International Organization for Standardization \\
\hline LQ & Limite de Quantificação \\
\hline MERCOSUL & Mercado Comum do Sul \\
\hline NACMCF & National Advisory Committee on Microbiological Criteria for Foods \\
\hline NASA & National Aeronautics And Space Administration \\
\hline NBR & Norma Brasileira \\
\hline NTU & Nephelometric Turbidity Unit \\
\hline OMC & Organização Mundial do Comercio \\
\hline
\end{tabular}




$\begin{array}{ll}\text { OMS } & \text { Organização Mundial da Saúde } \\ \text { PC } & \text { Ponto Critico } \\ \text { PCC } & \text { Ponto Crítico de Controle } \\ \text { PURA } & \text { Programa de Uso Racional da Água } \\ \text { QFD } & \text { Quality Function Deployment } \\ \text { SABESP } & \text { Companhia de Saneamento Básico do Estado de São Paulo } \\ \text { SGS } & \text { Société Générale de Surveillance } \\ \text { SGQ } & \text { Sistema de Gestão da Qualidade } \\ \text { TQM } & \text { Total Quality Management } \\ \text { UE } & \text { União Europeia } \\ \text { UNDP } & \text { United Nations Development Programme } \\ \text { USDA } & \text { United States Department of Agriculture } \\ \text { USP } & \text { Universidade de São Paulo } \\ \text { VMP } & \text { Valores Máximos Permitidos } \\ \text { WHO } & \text { World Health Organization }\end{array}$




\section{LISTA DE SIMBOLOS}

$\begin{array}{ll}\mathrm{L} & \text { litros } \\ \mathrm{L} / \mathrm{s} & \text { litros por segundo } \\ \mathrm{m}^{3} & \text { metros cúbicos } \\ \mathrm{mg} & \text { miligramas } \\ \mathrm{pH} & \text { potencial de hidrogênio } \\ \mathrm{MF} & \text { mocrofiltração } \\ \mathrm{NF} & \text { nanofiltração } \\ \mathrm{OR} & \text { osmose reversa } \\ \mathrm{UF} & \text { ultrafiltração; } \\ \mathrm{UV} & \text { radiação ultravioleta } \\ \mu \mathrm{m} & \text { micrometros } \\ \mu \mathrm{g} / \mathrm{L} & \text { microgramas por litro } \\ \mathrm{m}^{3} / \text { dia. } & \text { metros cúbicos por dia }\end{array}$




\section{SUMÁRIO}

1 INTRODUÇÃO

2 OBJETIVOS

2.1 Objetivos específicos

3 REVISÃO DE LITERATURA

3.1 Reúso de águas .08

3.1.1 Aspectos históricos 09

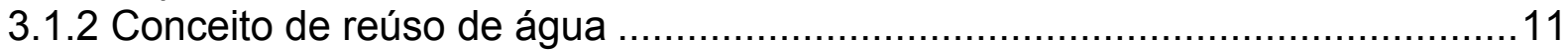

3.1.3 Reúso de água para fins Industriais .................................................. 14

3.1.4 Reúso de águas na indústria de alimentos.......................................... 18

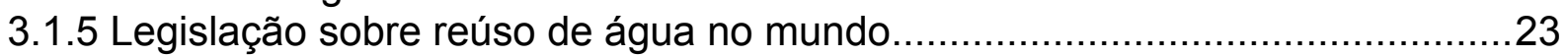

3.1.6 Legislação sobre reúso de água no Brasil...............................................24

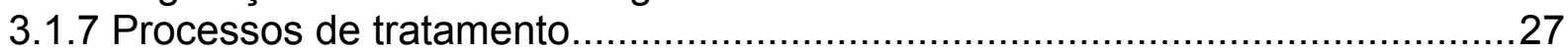

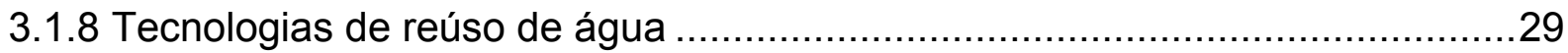

3.1.9 Critérios e padrões de qualidade de água .................................................. 30

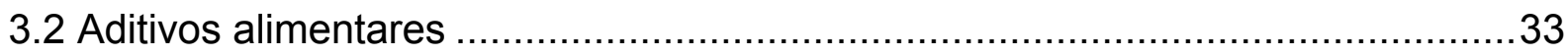

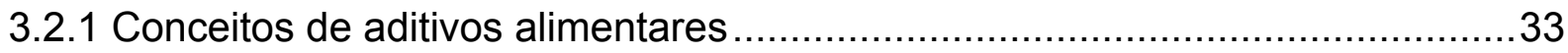

3.2.2 Tipos de aditivos alimentares ............................................................ 34

3.3 Sistemas de gestão da qualidade na indústria de alimentos .......................37

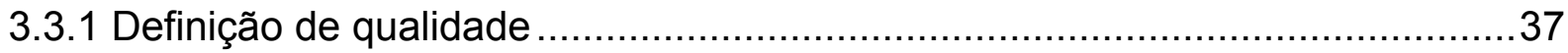

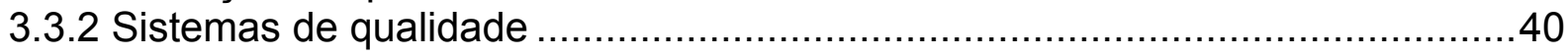

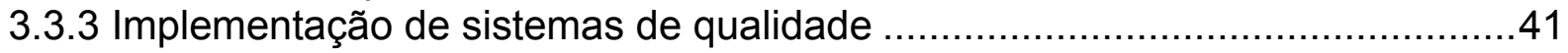

3.3.4 Padrões de qualidade na indústria de alimentos ......................................42

3.3.4.1 O Codex Alimentarius............................................................................ 42

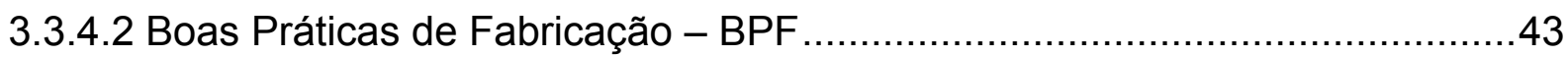

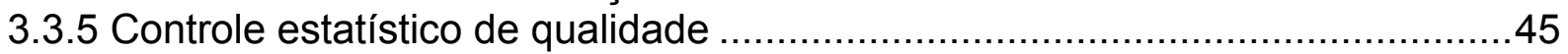

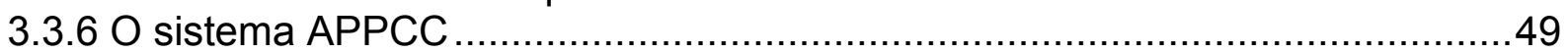

3.3.6.1 História do APPCC ........................................................................... 49

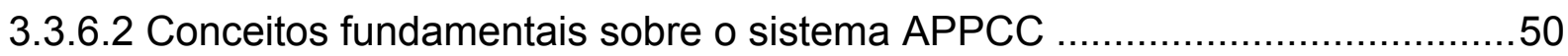

3.3.6.3 Os pré-requisitos do sistema APPCC ................................................. 53

3.3.6.4 Princípios básicos do sistema APPCC no reúso de águas ..........................53

3.3.6.5 Diretrizes para a aplicação do sistema APPCC ......................................61

3.3.7 ISO - International Organization for Standardization .................................63

3.3.7.1 A série ISO 22000:2005 - Sistema de gestão da segurança de alimentos...63 


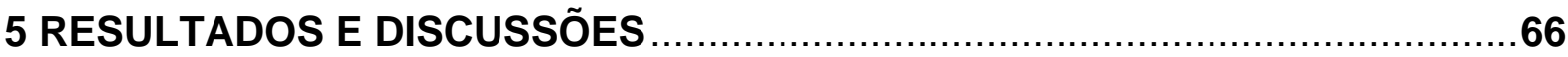

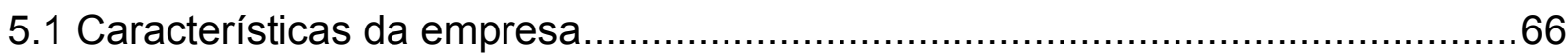

5.1.1 Sistema de abastecimento de água na planta......................................68

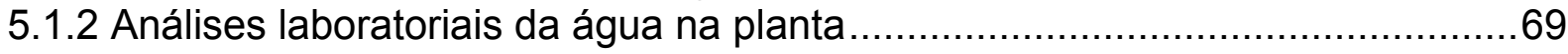

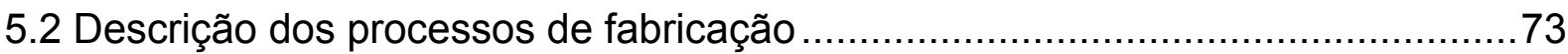

5.2 .1 Sistema de secagem de emulsões........................................................

5.2.2 Tanques móveis da área de aromas e essências. ..................................... 81

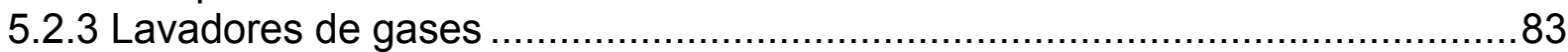

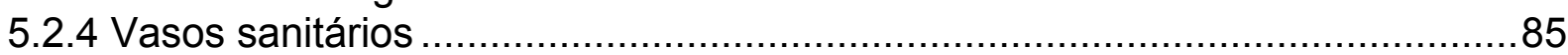

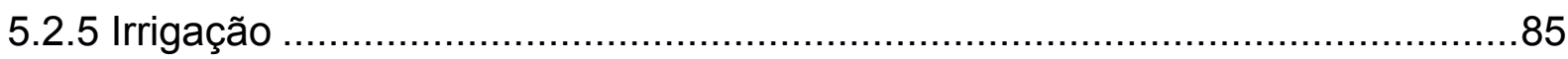

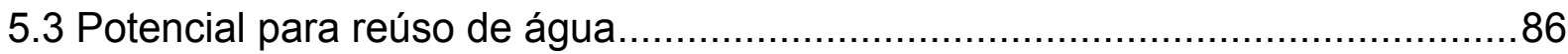

5.3.1 Aplicação do sistema APPCC no reúso de água .....................................88

5.3.2 Ações complementares para redução do consumo da água..........................95

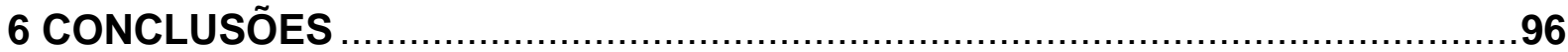

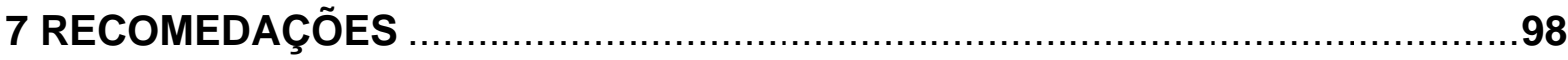

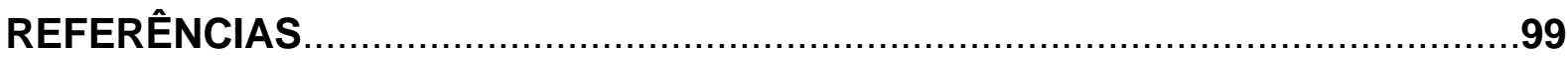




\section{INTRODUÇÃO}

Desde os primórdios da humanidade, as civilizações procuram se estabelecer às margens dos corpos de água. Isto porque, a água é um elemento indispensável à vida humana como também é insumo básico para o desenvolvimento e crescimento das atividades agrícolas, urbanas e industriais. Para exemplificar, podemos citar as cidades de São Paulo e Curitiba e suas regiões metropolitanas que se propagam sobre os mananciais do Rio Tietê e do Rio Iguaçu, respectivamente.

A água é vida, ela se apresenta em todos os aspectos vitais, direta ou indiretamente. Em conjunto com o ar, que se respira, e o solo, suporte da vida, a água constitui a mais importante parte do meio ambiente e o recurso mais precioso. Mesmo assim, com exceção de regiões áridas e semi-áridas do globo, seu valor é geralmente negligenciado até que alguma catástrofe, natural ou induzida pelo homem, force a atenção ao seu valor.

Embora seja indispensável ao organismo humano, a água pode conter determinadas substâncias, elementos químicos e microrganismos que devem ser eliminados ou reduzidos a concentrações que não sejam prejudiciais à saúde humana. A industrialização e o aumento populacional dos centros urbanos têm intensificado a contaminação dos mananciais tomando indispensável o tratamento de água para consumo humano. Apesar dos mananciais superficiais estarem mais sujeitos a poluição e contaminação decorrente de atividades antrópicas, também tem sido observada a deterioração da qualidade das águas subterrâneas, o que acarreta sérios problemas de saúde pública em localidades que carecem do tratamento e de sistema de distribuição de água adequado (DI BERNARDO, 2005).

A quantidade de água disponível no planeta é sempre a mesma já que está sempre sendo renovada através do ciclo hidrológico. Entretanto a água de qualidade para consumo está se tornando rara. Tem-se conhecimento, hoje em dia, que a água potável no planeta está se esgotando. É claro que existe muita água no planeta, mas cerca de $97,5 \%$ dessa água é salgada e está nos oceanos, $2,5 \%$ é doce sendo que 
deles, $2 \%$ estão nas geleiras, e apenas $0,3 \%$ está disponível nos corpos de água da superfície, isto é, rios e lagos, sendo que a maior parte, ou seja, 95\%, está no subsolo, considerado o grande reservatório de água doce da natureza. Veja-se na figura 1. (OLIVEIRA, 2002)

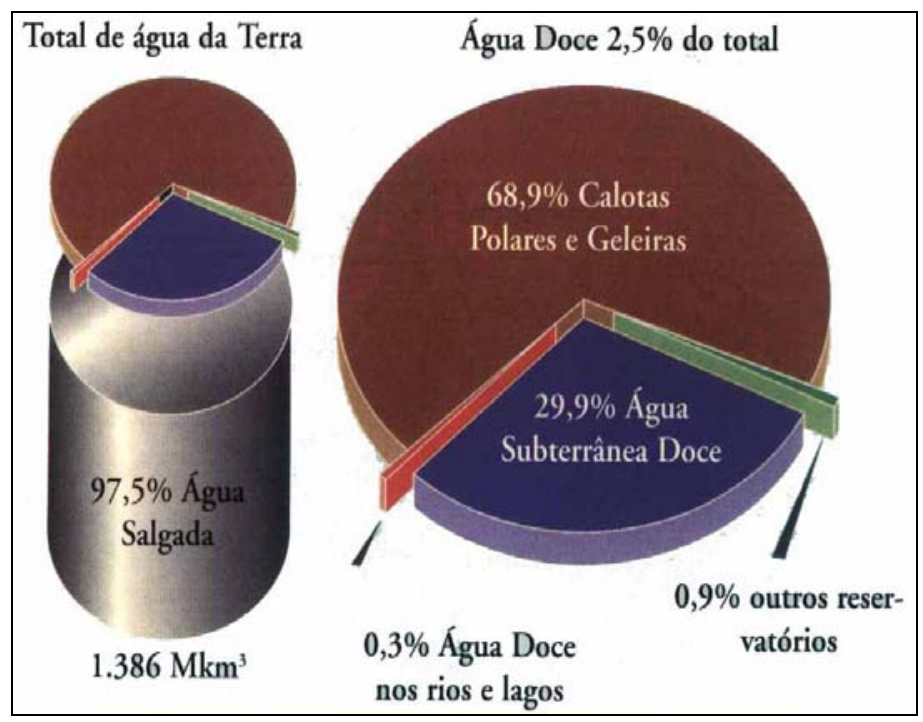

Figura 1 - Os volumes de água da Terra Fonte: OLIVEIRA, 2002.

O aumento populacional vem contribuindo para o aumento na demanda pelos recursos hídricos. Embora a água existente seja um recurso renovável, ela tende a se deteriorar em função do seu uso indiscriminado o que compromete, conseqüentemente, a quantidade de água com qualidade disponível para consumo nas diversas localidades.

Á medida que a população aumenta, a deteriorização dos mananciais se acentua e desta forma, surgem problemas de abastecimento que têm despertado a atenção e preocupação de populações e autoridades do mundo. Desta forma é necessária que haja uma gestão integrada do recurso água, incentivando-se o seu uso racional favorecendo o desenvolvimento de sistemas sustentáveis como forma de prevenção contra a escassez.

A demanda por água nos grandes centros urbanos fez com que fossem construídos complexos sistemas de captação em rios de grande porte, os quais têm córregos que cruzam núcleos urbanos e que recebem esgoto não tratado como contribuição. 
Com isto cresce os custos para o tratamento da água, o risco da oferta de água de má qualidade, e de desabastecimento nas estiagens.

O fenômeno da escassez está diretamente relacionado ao crescimento populacional e a conseqüente degradação ambiental. Não é problema exclusivo das zonas áridas e semi-áridas, pois muitas regiões com recursos hídricos abundantes, devido às elevadas demandas, também experimentam conflitos de usos e sofrem restrições ao consumo e desperdícios.

No Brasil, para muitas pessoas, a escassez de água não é vista como uma ameaça pelo fato do país dispor de uma das maiores Bacias Hidrográficas do Planeta. Contudo, as principais reservas de água estão nos rios da Bacia Amazônica, muito longe dos grandes centros urbanos e a qualidade de água que efetivamente abastece as maiores cidades estão se degradando com muita rapidez.

A carência de alimentos também está relacionada ao déficit hídrico. Em países no qual a falta de água é um fator limitante de crescimento, percebe-se a dependência externa de produtos agrícolas, como, por exemplo, grãos, que requerem alta demanda hídrica. Portanto, o problema de escassez de água é também um problema de escassez de alimentos.

A água de reúso é uma opção correta do ponto de vista ambiental, já que contribui para diminuição da captação e conseqüente redução nas vazões de lançamento de efluentes. Entretanto, para que possa ser utilizada deve-se levar em conta a questão da saúde pública. Existem padrões para reúso em alguns países do mundo que fazem do reúso de água para fins não potáveis, uma prática habitual. Entretanto, no Brasil, estas práticas são ainda incipientes.

O reúso de água já vem sendo amplamente empregado na indústria, principalmente em torres de resfriamento, caldeiras, construção civil, irrigação de áreas verdes e em alguns processos industriais onde a utilização de água com menor padrão de qualidade não ocasione maiores problemas. Desta forma, o reúso de água para fins não potáveis deve ser considerado como primeira opção para reúso (MIERZWA e HESPANHOL 2002). 
Uma das alternativas para integrar as atividades de reúso que pode ser considerada é utilização da água de rejeito de um processo produtivo, que necessita uma água com maior qualidade, em outro processo, que possa utilizar uma água com menor qualidade. Esta alternativa se mostra ambientalmente correta, entretanto continua incorporando impurezas aos corpos receptores de água. Outra alternativa mais interessante é o reúso da água em um ciclo fechado; isto é, após o uso da água em uma atividade qualquer, que resulta na incorporação de impurezas, tornar a obter uma água com qualidade inicial, utilizando um processo de tratamento adequado.

Ao longo do tempo, as indústrias de alimentos no Brasil têm passado por vários avanços tecnológicos relativos ao processamento e a conservação de alimentos, com vistas a ampliar sua atenção nos mercados internos e externos. A qualidade do alimento passou a ser uma exigência dos consumidores, que desejam produtos com boas características organolépticas e seguros para consumo. As características organolépticas estão relacionadas com a percepção dos sentidos dos consumidores pelo alimento. Para isto, este deve apresentar um sabor, odor, textura e transparência; a segurança, por sua vez, refere-se à saúde do consumidor, pois o alimento não deve causar danos a quem o ingere. O requisito de segurança do alimento, na maioria das vezes, é de difícil percepção e, por isso, tem chamado a atenção das autoridades de saúde, sejam nacionais ou internacionais.

A contaminação microbiológica é normalmente a mais ameaçadora à saúde humana; contudo, a presença de resíduos químicos também oferece grande ameaça, principalmente quando são analisados os efeitos de longo prazo. Além disso, a contaminação microbiológica pode ser bem controlada, pelas Boas Práticas de Higiene, durante o manuseio e processamento dos alimentos, enquanto a contaminação química é, em geral, bastante difícil de ser controlada. (BARENDSZ, 1998 apud FIGUEREIDO, 2001)

A preocupação com a qualidade em todas as etapas do processo é fundamental, tendo em vista a necessidade de fornecer um produto mais seguro ao consumidor utilizando uma técnica mais efetiva de controle que, em última análise, focaliza o controle dos perigos potenciais de contaminação quando se adota a prática de reúso de água. 
O reúso de água na indústria alimentícia vem atraindo muita atenção nos últimos anos devido ao acréscimo do custo tanto da água quanto da descarga de efluentes. Contudo, um dos principais obstáculos para o reúso extensivo é o risco associado à contaminação microbiológica dos alimentos e do ambiente de produção. Portanto, um modelo genérico baseado na Análise de Perigos e Pontos Críticos de Controle APPCC ou (Hazard Analysis Critical Control Point - HACCP) pode ser elaborado com a finalidade de implementar e avaliar sistemas de reúso de água na indústria alimentícia. O modelo inclui informações sobre o processo produtivo, a água, os patógenos potencialmente presentes e a sua sensibilidade aos diversos métodos de tratamento.

A fim de implementar um sistema seguro de reúso de água na indústria alimentícia, a implementação prévia dos programas pré-requisitos bem como a combinação de conhecimento de muitas áreas de pesquisa é necessária.

A técnica de APPCC é um procedimento preventivo que busca a produção de alimentos inócuos. Ela está baseada na aplicação de princípios técnicos e científicos na produção e manejo dos alimentos desde sua origem até o consumidor final. Os princípios do APPCC são aplicáveis a todas as fases da produção e distribuição e utilização de um produto.

O objetivo de qualquer programa APPCC é o prevenir o aparecimento de contaminações que possam apresentar perigo para a saúde pública, através da identificação de perigos específicos (químicos, físicos e microbiológicos) e da especificação das medidas para o seu controle.

A severidade de determinado perigo é função da sua possibilidade de ocorrência, das suas conseqüências na saúde do consumidor e no grau de exposição, isto é, no tempo a que o consumidor estará exposto ao perigo.

Este sistema baseia-se na aplicação de sete princípios básicos, estabelecidos pelo Codex Alimentarius Comission (CAC); National Advisory Committee on Microbiological Criteria for Foods (NACMCF); e Campden Food Drink Research Association (CFDRA). 
A análise de acidentes é o primeiro passo dos planos APPCC e consiste na elaboração do fluxograma de todas as etapas de produção e na elaboração de um cadastro atualizado de todas as infra-estruturas, de modo a identificar todas as etapas do processo e prever onde podem ocorrer os perigos, o tipo de acidente, o risco que lhe está associado e as medidas preventivas que podem ser tomadas para controlar o perigo (Principio $\mathrm{n}^{\circ} 1$ ). Com base no levantamento efetuado definem-se os pontos críticos para controle PCC (Principio $n^{\circ} 2$ ). Na etapa seguinte devem ser estabelecidos os limites críticos e a tolerância para cada acidente em cada PCC (Principio $n^{\circ} 3$ ). Após a execução dos três primeiros princípios, os restantes são meramente documentais, incluindo os procedimentos de monitoramento ou vigilância programada dos PCC, a freqüência de análise e os recursos humanos envolvidos (Principio $n^{\circ} 4$ ), os procedimentos a serem aplicados sempre que os limites críticos forem ultrapassados (Principio $n^{\circ} 5$ ), os procedimentos de coleta e registro de dados (Principio $n^{\circ} 6$ ) e os procedimentos de verificação de todo o plano APPCC (Principio $n^{\circ} 7$ ).

Assim o uso da ferramenta de APPCC pode ser de extrema relevância para a implantação de programas de reúso em indústrias do setor alimentício, contribuindo para a minimização dos problemas associados à escassez de água. 


\section{OBJETIVOS}

O objetivo deste trabalho pretende desenvolver uma discussão da aplicação do sistema APPCC - Análise de Perigos e Pontos Críticos de Controle, como ferramenta na avaliação da qualidade da água para reúso, aceitável para diferentes propósitos usados nos processos produtivos na indústria de alimentos, garantindo a segurança e a qualidade, utilizando-se como estudo de caso uma indústria do setor de aromas e essências,

\subsection{Objetivos específicos}

- Analisar os processos e operações desenvolvidas na indústria de alimentos de aromas e essências para implantar e otimizar a prática de reúso de água;

- Identificar os principais problemas e dificuldades para a implementação do sistema APPCC como ferramenta no reúso de água no processo produtivo;

- Determinar os Pontos Críticos de Controle (PCC) em uma etapa representativa do processo produtivo;

- Indicar o processo de tratamento simplificado para melhoria da qualidade da água para reúso que não implique em manutenção sofisticada e onerosa;

- Demonstrar a viabilidade da aplicação da prática de reúso em indústrias do ramo alimentício. 


\section{REVISÃO DE LITERATURA}

\subsection{Reúso de águas}

A limitação de reservas de água doce no planeta, o aumento da demanda de água para atender, principalmente, os consumos humano, agrícola e industrial, a prioridade de utilização dos recursos hídricos disponíveis para abastecimento público e as restrições que vêm sendo impostas em relação ao lançamento de efluentes no meio ambiente, torna necessária a adoção de estratégias que visem racionalizar a utilização dos recursos hídricos e mitigar os impactos negativos relativos à geração de efluentes pelas indústrias (HESPANHOL e GONÇALVES, 2005).

O problema do uso indiscriminado dos recursos hídricos é detectado nas grandes regiões urbanizadas do Brasil, como nas cidades de Rio de Janeiro e São Paulo, onde há grande demanda de água devido ao crescimento populacional e cujos recursos hídricos superficiais apresentam restrições devido à poluição, resultante do lançamento de esgotos domésticos e despejos industriais nos corpos de água.

Dada a importância de consciência de escassez dos recursos hídricos, e, conseqüência disto, a cobrança pelo uso da água encarecendo este insumo, é inevitável se buscar formas alternativas para as indústrias continuarem seus processos produtivos, que necessitam impreterivelmente do insumo água. O reúso de água torna-se uma opção a ser adotada, diminuindo, assim, a captação deste recurso natural.

Em condições naturais, o ciclo hidrológico faz com que a água seja um recurso renovável, limpo e seguro. No entanto, se o manancial sofre interferências antrópicas, o grau de poluição das águas pode exceder sua capacidade natural de recuperação e passa a exigir do próprio homem ações corretivas para sua recuperação, o que envolve o estabelecimento de critérios de segurança e de custos associados ao sistema de tratamento adotado. 
As águas residuárias, tais como os esgotos domésticos e águas de drenagem agrícola, assim como as águas salobras, podem ser consideradas como fontes alternativas para usos menos restritivos e o uso de tecnologias apropriadas para o aproveitamento destas fontes é fundamental para o enfrentamento do problema da falta de água (HESPANHOL, 2002).

Sabe-se que a palavra esgoto, em seu sentido amplo, caracteriza os despejos oriundos dos mais diversos usos da água. O esgoto de uma comunidade é originado através de três fontes distintas: a primeira diz respeito à contribuição doméstica, incluindo residências, instituições públicas e comércio; a segunda é aquela que adentra a rede por infiltração através de tubos defeituosos e, a terceira refere-se aos despejos industriais.

O reúso da água é uma medida de gestão integrada e racional, cada vez mais utilizada em diversos países. O reúso mais nobre da água se dá quando o tratamento de esgoto é bem feito e é inserido no próprio sistema e essa água pode ser reutilizada para abastecer cidades.

No Estado de São Paulo, as empresas pagam $\mathrm{R} \$ 8,75$ pelo metro cúbico de água acrescidos do mesmo valor pelo esgoto descartado, ou seja, um total de $\mathrm{R} \$ 17,50$ por metro cúbico. "Este é um valor muito alto para as indústrias. A água reutilizada tem um custo médio de $\mathrm{R} \$ 5,50$ o metro cúbico".

\subsubsection{Aspectos históricos}

O reúso de água já é praticado há muito tempo, como mostra a história. As primeiras evidências da utilização de esgotos na agricultura são referidas à civilização de Minoam na Grécia (ASANO e LEVINE, 1998 apud MANCUSO, 2001).

Outra evidencia de preocupação com a qualidade da água para usos mais nobres, remontam da Roma antiga (97 A.C, onde os operadores dos aquedutos romanos classificavam as águas transpostas em função de sua qualidade e abundância, atribuindo usos diferenciados para cada uma delas (SILVA et al. 2003). 
Em meados do século XIX, com a evolução dos grandes conglomerados urbanos e de sistemas de esgotamento sanitário que conduziam os esgotos para disposição em corpos de água, é que foram constatadas as primeiras evidências do reúso de águas para fins potáveis - no caso não planejado, ou seja, as comunidades que se instalavam a jusante destes centros urbanos consumiam águas que já teriam sido utilizadas. Este fato, associado à escassez de tecnologias para o tratamento de água e esgotos resultou nas catastróficas epidemias dos anos 1840 e 1850 como a febre asiática e febre tifóide. (ASANO e LEVINE; 1998 apud MANCUSO, 2001).

A partir da década de 1910, surgem as primeiras normas e regulamentos para a prática do reúso. O estado da Califórnia foi o pioneiro neste processo, promulgando em 1918, o primeiro regulamento para prática do reúso.

Na década de 1990, Israel já utilizava $70 \%$ de sua água de esgoto, irrigando de forma segura 20,000 hectares de terra. (TOMAZ, 2001).

Segundo Asano e Levine (1998) apud Paludetto (2002) dividem em três grupos a evolução do reúso de águas na historia da humanidade: (1) Primeiros Sistemas de Água e Esgotamento Sanitário, (2) Grande Revolução Sanitária e (3) Era do reúso de Água.

As experiências mundiais em matéria de utilização de esgotos tratados para a agricultura irrigada e para a criação de peixes têm apresentados resultados convincentes em termos dos benefícios diretos (econômicos) e indiretos, tais como o incremento do nível nutricional e a melhoria das condições de vida das populações mais pobres, pelo aumento da produção de alimentos e a redução de danos ambientais (HESPANHOL, 2002).

Um caso clássico de reúso é o projeto implantado em Lima, Peru, pela United Nations Development Programme (UNDP), do World Bank Integrated Resource Recovery Project, e com assistência técnica Alemã. Nesse empreendimento, peixes e camarões são criados em lagoas de estabilização de polimento (MANCUSO e SANTOS, 2003). 
No Japão, o reúso de água vem sendo realizado desde 1964. Geralmente os esgotos sanitários são submetidos a tratamento primário, secundário e terciário e após desinfecção são usados principalmente para descargas sanitárias. O custo de água potável no Japão é de US\$ $3,73 / \mathrm{m}^{3}$, enquanto que a água para reúso é de $2,99 / \mathrm{m}^{3}$, portanto, a água para reúso é cerca de $80 \%$ do custo da água potável. Mesmo assim, o Japão reaproveita anualmente $200.600,000 \mathrm{~m}^{3}$ de esgoto sanitário (dados de 1998) com o objetivo da conservação da água e se prevenir de secas (TOMAZ, 2001).

\subsubsection{Conceitos de reúso de água}

Em razão da crescente conscientização da limitação do recurso natural água e sua inevitável escassez, necessária se fazem alternativas que sejam possíveis para o consumo racional e sustentável da água, a fim de que se preserve para as presentes e futuras gerações, um bem essencial a sobrevivência de todo meio ambiente.

O reúso de água reduz a demanda sobre os mananciais devido à substituição da água potável por uma água de qualidade inferior. Esta prática, atualmente muito discutida e posta em evidência, já é utilizada em alguns paises. Isto é possível em função da qualidade do efluente disponível (tratado ou não), ser compatível com os requisitos exigidos para um uso especifico (SILVA et al. 2003).

Embora a importância do conceito de reúso de água seja conhecida há muitos séculos, só recentemente é que a sua filosofia começa a conquistar adeptos e a se consolidar no Brasil, com o surgimento das preocupações sobre a gestão e conservação dos recursos hídricos.

Além da necessidade de economia, a reciclagem e a reutilização aparecem como alternativas para o uso racional da água. A reciclagem pode ser definida como o reaproveitamento de uma água utilizada para determinada função, apesar da alteração de suas qualidades físico-quimicas e microbiológicas. 
Como o reúso de água não está institucionalizado no Brasil, pode ocorrer de ele ser feito de uma forma não planejada e inconsciente, por não incluir na sua prática barreiras de proteção para garantir a Saúde Pública.

Para Lavrador Filho (1987), reúso de água é o aproveitamento de águas previamente utilizadas, uma ou mais vezes, em alguma atividade humana, para suprir as necessidades de outros usos benéficos, inclusive o original. Pode ser direito ou indireto, bem como decorrer de ações planejadas ou não.

Quando o reúso ocorre para outro propósito, essa água é vendida ou beneficia uma área distinta da originalmente prevista, o direito apropriativo original pode ser contestado se estiver prejudicando os direitos dos usuários da jusante, pois o novo uso torna-se sucessivo, diferindo do conceito de reúso para o bem público (FINK, 2002 apud SILVA et al. 2003).

A demanda de água na indústria representa cerca de um quarto da demanda mundial de água e, especificamente no Japão, essa cifra chega a 55\%; na Alemanha $75 \%$, e mais de $66 \%$ do consumo de água total no Reino Unido (VALIRON, et al. 1983, apud MANCUSO, 2001).

Segundo Sleeman e Barret (1996) apud Casani e Knockel, (2002), 16\% do consumo de água potável em paises desenvolvidos é água usada nas indústrias. A preocupação crescente com a disponibilidade contínua de água potável de alta qualidade e a necessidade de minimização de poluição do ambiente tem resultado no acréscimo do custo da água limpa e, em particular, da descarga de água suja.

O reúso de água vem se tornando um tema importante na indústria. A água é utilizada para muitos processos e fins na indústria alimentícia; por exemplo, é usada como insumo, como parte do processo de manufatura e em contato direto com o material alimentício ou em algum contato indireto no produto alimentício (PORETTI, 1990 apud CASANI e KNOCKEL, 2002). 
A indústria alimentícia consome grandes quantidades de água, mas até agora, o reúso de água é bem limitado devido às restrições legislativas e às preocupações higiênicas (CASANI et al. 2004).

As indústrias processadoras de alimentos seguem duas estratégias a fim de poupar água: desenvolvendo operações de processos que usem menor quantidade de água, conservação e reúso. (BIRK e HEAGG, 1998 apud CASANI e KNOCKEL, 2002).

Com relação ao reúso no setor alimentício, assim como em muitos outros, deve ter em consideração que o conceito tradicional de reúso leva interpretações incorretas, pois se imagina o aproveitamento do efluente final de uma indústria em um processo onde se manipula o alimento.

$\mathrm{Na}$ indústria alimentícia a água utilizada, qualquer que seja a fonte de abastecimento, deve ter, no mínimo, qualidade equivalente à da água potável, exigência estabelecida pelas autoridades locais. Muitas unidades de processamento de alimento procuram acrescentar o reúso de água em processos além dos usos atualmente aprovados, os quais incluem limpeza inicial de vegetais e cozinhado nos abatedouros de carne e aves domésticas (RAJKOWSKI et al. 1996 apud CASANI e KNOCKEL, 2002).

As possibilidades e formas potenciais de reúso dependem, evidentemente, das características, condições e fatores locais, tais como decisão política, esquemas institucionais, disponibilidade técnica e fatores econômicos, sociais e culturais. A figura 2, apresenta, esquematicamente, os tipos básicos de uso potenciais de esgotos tratados, que podem ser implementados, tanto em áreas urbanas como em áreas rurais (HESPANHOL,2002). 


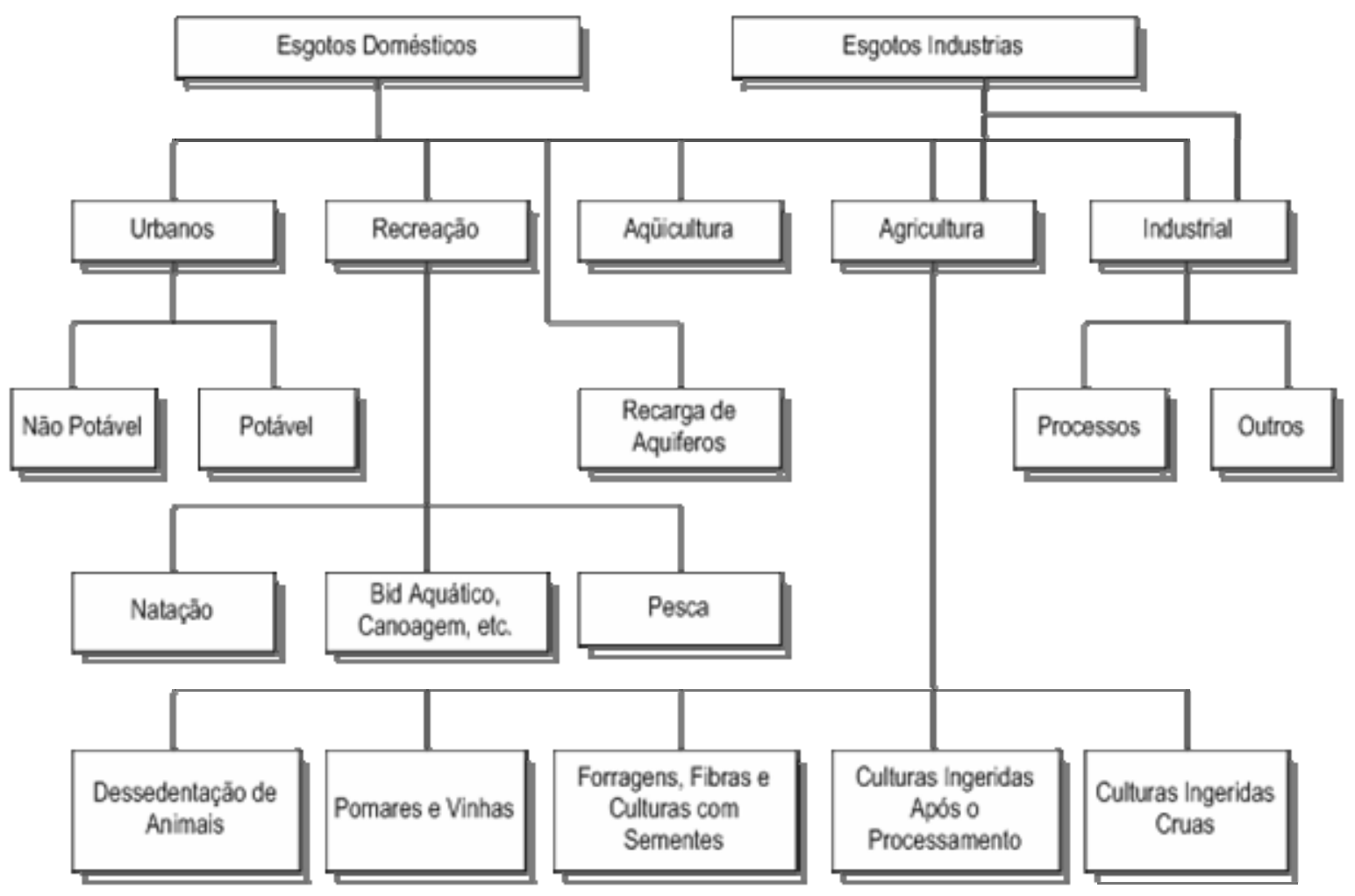

Figura 2 - Formas potenciais de reúso de água.

Fonte: HESPANHOL (2002).

\subsubsection{Reúso de água para fins Industriais}

A indústria é o segundo maior usuário de águas, principalmente para atender as demandas dos processos. Entretanto, o reúso de água na indústria varia bastante e, na maioria das vezes, requer um tratamento adicional das águas residuárias após tratamento secundário, dependendo da aplicação que se pretende dar à água de reúso e também da fonte de efluentes que será utilizada. Em geral, a prática de reúso é uma alternativa que afeta o consumo, mas não a carga de contaminantes.

A quantidade de água necessária para o atendimento das diversas atividades industriais é influenciada por vários fatores como: o ramo de atividade, capacidade de produção, condições climáticas da região, disponibilidade de água, método de produção, idade das instalações, práticas operacionais, cultura da empresa, inovação tecnológica, investimentos em pesquisa, etc.

Para reduzir o consumo de água na indústria deve-se buscar a melhoria dos processos de fabricação, visto que a geração de efluentes aquosos decorre quando 
a água entra em contato com materiais de processo, em operações de transferência de massa (difusão de substâncias entre correntes liquidas), de lavagem (dissolução de substancias) troca térmica por contato direto de ejetores de vapor ou água, tratamento de água e descarga de caldeiras, descarga de torres de resfriamento e outros processos (DA SILVA e SIMÕES, 1999).

A água é utilizada em diferentes tipos de processamento de alimento e nas diversas operações unitárias; por exemplo: lavagem, enxágüe, branqueamento, aquecimento, pasteurização, resfriamento, refrigeração, produção do vapor, como insumo, e para finalidades gerais da limpeza, saneamento e desinfecção (CASANI, 2004).

Dada a importância da consciência de escassez dos recursos hídricos, e, conseqüência disto, a cobrança pelo uso da água encarecendo este insumo, é inevitável a busca de formas alternativas para as indústrias continuarem seus processos produtivos que necessitam, impreterivelmente, do insumo água. O reúso de água vem como opção a ser utilizada diminuindo assim a captação deste recurso natural.

Em termos de reúso industrial, a prática começa a ser implementada, mas ainda está associada a iniciativas isoladas, principalmente no Brasil, e a maioria das quais no setor privado, sendo que ainda não existem dados disponíveis na literatura nacional.

As companhias estaduais de água e esgoto já estão envolvidas no processo. Neste sentido, a Companhia de Saneamento Básico do Estado de São Paulo - SABESP, já realiza e vai ampliar ainda mais o reúso planejado de água em suas instalações de tratamento de água (recirculação de água de lavagem de filtros, por exemplo) e de esgotos. Para o setor industrial, a empresa está aberta a negócios em torno do reúso da água com sistemas apropriados de distribuição. A reutilização de água apresenta atrativos, como menor custo, confiabilidade tecnológica e suprimento garantido.

Os principais processos industriais que permitem o uso de água de reúso são os de produtos de carvão, petróleo, produção primaria de metal, curtumes, indústrias 
têxteis, químicas e de papel celulose. E os focos principais de usos industriais são: torres de resfriamento, caldeiras, construção civil, incluindo preparação e cura do concreto, e para compactação do solo, irrigação de áreas verdes de instalações industriais, lavagens de pisos e alguns tipos de peças, principalmente na indústria mecânica e processos industriais (SILVA et al. 2003).

Empresas como a General Electric Dako Aplliances, uma das maiores fabricantes mundiais de fogões, vem investindo em gestão ambiental na unidade de Campinas. O programa resultou no período de 1999 e 2001 num ganho de 5\%, em produtividade e redução de desperdícios. Esse ganho foi dividido na melhoria da rentabilidade da unidade brasileira e em ganhos de competitividade no mercado de linha branca. Uma base de 3,5 mil metros cúbicos de água por mês já são reutilizados em atividades que não exigem água potável, entre os quais descargas em bacias sanitárias, rega de jardins e parte do processo industrial. Isso reduziu a chamada captação de água industrial de um poço artesiano local, fonte de água utilizada no processo de produção. A demanda mensal suprida por esse poço é de 2,6 mil metros cúbicos por mês. A economia obtida com essa medida ultrapassa os $\mathrm{R} \$ 680$ mil reais por ano. Dentre todos, os maiores retornos provêm da estação de tratamento biológico. Em torno de $70 \%$ da água tratada nesta unidade voltam para usos secundários dentro da empresa. (BRITO, 2002 apud SILVA et al. 2003).

A Votorantim Celulose e Papel, no Vale do Paraíba, investem, desde a década de 1990, em tecnologia limpa e já obtiveram resultados significativos na redução de consumo de água por tonelada produzida em todas as unidades, mesmo com aumento de produção. Este é um reflexo de práticas de fechamento parcial de circuito e da reutilização da água consumida no processo. A qualidade dos efluentes é avaliada sistematicamente em todo o processo produtivo. Estações de tratamento permitem reduzir a carga de matéria orgânica para níveis abaixo de 3 quilos/tonelada. O resíduo de maior carga tóxica (licor negro) desses efluentes é queimado para gerar vapor nas caldeiras. Além disso, nas unidades da empresa, o reuso chega a $85 \%$. Com tudo isso, a carga dos efluentes é mantida bastante abaixo dos padrões exigidos pela legislação nacional e internacional. 
A Cervejaria Kaiser, em Jacareí, também no Vale do Paraíba, e as refinarias da Petrobrás também servem de exemplo de indústrias com projetos de reúso de água (MIRANDA, 2002 apud SILVA et al. 2003).

A Fiat, em sua planta industrial em Betim (MG), atingiu a marca de reaproveitamento de $92 \%$ dos 1,5 bilhões de litros de água usados continuamente na produção. Com o reúso, a empresa economiza a compra mensal de 1,3 bilhões de litros de água (LOBATO, 2002 apud SILVA et al. 2003).

O parque Temático Hopi Hari utiliza águas de reúso para irrigação, lavagem de pátios, e principalmente para descarga sanitária. Possuem reservatórios de água de reúso e água potável (MANCUSO, 2002 apud SILVA et al. 2003).

As águas residuais e efluentes de uma empresa, que são recebidas por outras indústrias que necessitam de água de menor qualidade, são o que hoje se denomina de ecossistemas industriais (SILVA et al. 2003).

Para análise da implantação do reúso de efluentes na indústria, há duas alternativas a serem consideradas. A primeira delas refere-se ao reúso macro externo, definido como o reúso de efluentes provenientes de estações de tratamento administradas por concessionárias ou outras indústrias. A segunda é o reúso macro interno, definido como o uso interno de efluentes, tratados ou não, provenientes de atividades realizadas na própria indústria (HESPANHOL e GONÇALVES, 2005).

O reúso de efluentes tratados é o tipo de reúso mais amplamente discutido nos dias atuais e consiste na utilização de efluentes que foram submetidos a um processo de tratamento. Em função da complexidade da atividade na qual se pretende aplicar a prática de reúso é necessário conduzir um estudo detalhado de implantação para cada uma das opções disponíveis. Em muitos casos, pode ser necessário promover alterações nos procedimentos de coleta e armazenagem de efluentes, principalmente quando o enfoque é o reúso em cascata.

Reúso em Cascata é quando o efluente originado em um determinado processo industrial é diretamente utilizado em um processo subseqüente, devido ao fato das 
características do efluente disponível serem compatíveis com os padrões de qualidade da água a ser utilizada. (HESPANHOL e GONÇALVES, 2005).

\subsubsection{Reúso de águas na indústria de alimentos}

A indústria de alimento é caracterizada pelo elevado consumo da água por tonelada de alimento produzido. Na Alemanha, por exemplo, uma tonelada de cenoura cozida produz $30 \mathrm{~m}^{3}$ de água residual, $1,2 \mathrm{~m}^{3}$ para o suco de maçã, $4,15 \mathrm{~m}^{3}$ para a produção da cerveja, e 1,7 $\mathrm{m}^{3}$ para chuveiros do resfriador durante o processamento de carne (CHMIEL et al. 2000, apud CASANI, 2004).

A implementação de práticas de reúso de água na indústria alimentícia apresenta um grande desafio em termos de conhecimento, experiência e documentação, tanto da empresa privada quanto das autoridades públicas de saúde. Há aspectos regulamentares, tecnológicos, de monitoramento, de verificação e éticos associados ao reúso de água praticado com segurança microbiológica na indústria alimentícia.

No Brasil, atualmente, existem vários obstáculos que impedem a implantação de maiores programas de reúso da água na indústria de alimento, tendo como risco mais relevante o microbiológico e a regulamentação estabelecida pelas autoridades de saúde. A qualidade microbiológica da água a ser reusada deve ser garantida e monitorada o tempo todo, sendo, portanto imprescindível o uso de uma análise de perigos e pontos críticos de controle (APPCC), uma ferramenta de gerenciamento de segurança sistemática (NOTERMANS et al. 1994 apud CASANI e KNOCKEL, 2002).

O reúso da água na produção de alimentos foi primeiramente limitado à limpeza de alimentos; usando-se geralmente uma fácil limpeza (por exemplo, água recuperada na fabricação de leite por meio de filtração), para funções de resfriamento, e para facilitar extinção do fogo (KATSUYAMA, 1979 apud CASANI et al. 2004).

A água processada pode ser recuperada e reusada diretamente ou após um tratamento. Exemplos de reúso direto encontrados é a lavagem ou água refrigerada na manufatura da manteiga, condensadores de evaporadores na indústria de laticínios, e água recuperada para pressionar a polpa e para lavar a casca da laranja 
ao preparar um pó dietético elevado de fibra. (LARRAURI et al. 1997 apud CASANI et. al 2004).

A indústria de alimento apresenta um uso extensivo da água, no momento, práticas de reúso da água têm cabimento apenas no fornecimento de água para torres de resfriamento, limpeza ou como água durante o processo, especialmente após um tratamento. Porém, as aplicações são muito limitadas quando comparadas com o potencial de reúso da água (PALUMBO et al., 1997 apud CASANI et al. 2004).

Um estudo realizado na Holanda concluiu que um potencial do reúso é o fechamento do ciclo da água existente na indústria de alimento $\mathrm{e}$, dependendo do setor alimentício, torna possível uma redução entre $20 \%$ e $50 \%$ do uso da água (HIDDINK et al., 1999 apud CASANI et al. 2004)

Segundo Pagella et al (2000) apud Casani et al (2004), uma abordagem estratégica para reúso de água deve ser baseada numa análise sistemática e no princípio que os usuários não usarão água de maior qualidade do que a estritamente requerida. Esse princípio pode parecer excessivo, mas não existe dúvida que a qualidade, quantidade e disponibilidade de água de reúso precisam ser equilibradas e compensadas.

O desenvolvimento de operações nas unidades que usam menos quantidade de água, por exemplo, nos sistemas de pulverização para lavagem de tomates, uso do vapor para limpeza de latas e frascos de vidro em fábricas de conservas de vegetais e de frutas, lavagem do pulverizador de carne, da como resultado um menor consumo de água e da carga dos desperdícios gerados durante processos de limpeza (PORDESIMO et al., 2002 apud CASANI, et al 2004).

Os exemplos dos tratamentos para vários tipos de reúso de água na indústria de alimentos são mostrados na tabela 1 . 
Tabela 1 - Exemplos dos processos de tratamentos para reúso de água na indústria de alimento.

\begin{tabular}{|c|c|c|}
\hline Processo produtivo & Tipo de água & Método de tratamento da água \\
\hline \multirow{2}{*}{$\begin{array}{l}\text { Ovo } \\
\text { Vegetais frescos e saladas }\end{array}$} & Água para lavagem & Detergente alcalino+ Sanitizante \\
\hline & $\begin{array}{l}\text { A água residual coletada } \\
\text { no tanque do contrapeso }\end{array}$ & Bioreator+UF+OR+UV \\
\hline \multirow{3}{*}{$\begin{array}{l}\text { Vegetais } \\
\text { Processamento de batata } \\
\text { Conserva de pepinos }\end{array}$} & Água para lavagem & Sedimentação + Filtração \\
\hline & Água para lavagem & Sedimentação \\
\hline & $\begin{array}{l}\text { Água para cozinhado na } \\
\text { salmouras de conserva }\end{array}$ & Adição do dióxido de cloro e $\mathrm{NaOH}$ \\
\hline Produção de leite & $\begin{array}{l}\text { Água para lavagem dos frascos } \\
\text { Condensado de vapor }\end{array}$ & $\begin{array}{l}\text { Filtro de areia + cloro gasoso } \\
\text { Pre-filtração + NF+ UV }\end{array}$ \\
\hline \multirow[t]{2}{*}{ Processamento de peixes } & $\begin{array}{l}\text { Salmouras para Refrigeração } \\
\text { na pesca armazenado nas } \\
\text { embarcações }\end{array}$ & UF \\
\hline & $\begin{array}{l}\text { A água recuperada da máquina } \\
\text { de enfaixado }\end{array}$ & OR \\
\hline \multirow[t]{2}{*}{ Produção de Surimi } & A água da primeira lavagem & Centrifugação + UF \\
\hline & Água de lavagem & UF \\
\hline \multirow{2}{*}{$\begin{array}{l}\text { Processamento de carne } \\
\text { Processamento dos suínos }\end{array}$} & Esfriamento com chuveiro & Pre-filtração + NF+ OR +UV \\
\hline & $\begin{array}{l}\text { Cozinhado da carcaça, água } \\
\text { para limpeza e polimento }\end{array}$ & Tratamento secundário + cloração \\
\hline \multirow{5}{*}{$\begin{array}{l}\text { Produção de Lingüiça } \\
\text { Produção de salsicha } \\
\text { Processamento de aves }\end{array}$} & Pulverização com água fria & NF + UV + cloração \\
\hline & Salmouras esfriadas & MF \\
\hline & Água para lavagem de carcaça & Peneiramento + filtração + ozonização \\
\hline & Água para resfriamento & Filtração + cloração \\
\hline & Água para resfriamento & Filtração + ozonização \\
\hline Produção da cerveja & $\begin{array}{l}\text { Água a pressão para quebrar } \\
\text { os grãos de cevada. }\end{array}$ & Centrifugação \\
\hline \multirow{3}{*}{$\begin{array}{l}\text { Produção do Gelo } \\
\text { Lavagem de frascos } \\
\text { Producão de alimentos }\end{array}$} & Esterilização da água & Ozônio \\
\hline & Água de lavagem & Pre-filtração + NF + OR + UV \\
\hline & Esterilização da água inicial & Ozonização \\
\hline
\end{tabular}

MF: Microfiltração; NF: Nanofiltração; OR: Osmose reversa; UF: Ultrafiltração; UV: Radiação ultravioleta.

Fonte: CASANI et al (2004).

As fontes potenciais para reuso de água podem ser avaliadas estabelecendo o uso e as características da água nas deferentes operações unitárias de uma planta pertencente ao setor alimentício (CASANI et al. 2004).

No passado, as unidades de processamento de alimento coletavam o efluente dos diferentes processos num único sistema de tratamento. Entretanto, parece que o efluente se separara em cada processo permitindo o ótimo tratamento para cada 
tipo. Isto pode conduzir à complexidade, mas a separação de pequenas concentrações de efluentes pode resultar na economia de energia, alta eficiência e custos mais baixos de tratamento, descarga e reúso, o qual foi observado numa fábrica de refrigerantes (MIYAKI et.al, 2000 apud CASANI et al. 2004).

De uma maneira genérica, pode-se dizer que a água encontra as seguintes aplicações na indústria: (HESPANHOL e GONÇALVES, 2005).

\section{a) Consumo humano}

Água utilizada em ambientes sanitários, vestiários, cozinhas e refeitórios, bebedouros, equipamentos de emergência (lava-olhos, por exemplo) ou em qualquer atividade doméstica com contato humano direto.

\section{b) Matéria Prima}

Como matéria-prima, a água será incorporada ao produto final, a exemplo do que ocorre nas indústrias de cervejas e refrigerantes, de produtos de higiene pessoal e limpeza doméstica, de cosméticos, de alimentos e conservas e de fármacos, ou então, a água é utilizada para a obtenção de outros produtos: por exemplo, o hidrogênio por meio da eletrólise da água.

\section{c) Uso como fluido auxiliar}

A água, como fluido auxiliar, pode ser utilizada em diversas atividades, destacandose a preparação de suspensões e soluções químicas, compostos intermediários, reagentes químicos, veículo, ou ainda, para as operações de lavagem.

\section{d) Uso para geração de energia}

Para este tipo de aplicação, a água pode ser utilizada por meio da transformação da energia cinética, potencial ou térmica, da água, em energia mecânica e posteriormente em energia elétrica. 


\section{e) Uso como fluído de aquecimento elou resfriamento}

Nestes casos, a água é utilizada como fluido de transporte de calor para remoção do calor de misturas reativas ou outros dispositivos que necessitem de resfriamento devido à geração de calor, ou então, devido às condições de operação estabelecidas, pois a elevação de temperatura pode comprometer o desempenho do sistema, bem como danificar algum equipamento.

\section{f) Outros Usos}

Utilização de água para combate a incêndio, rega de áreas verdes ou incorporação em diversos subprodutos gerados nos processos industriais, seja na fase sólida, líquida ou gasosa.

Um programa de reúso para a indústria, devido às diferenças existentes entre os diversos ramos de atividade, além da distribuição espacial das indústrias em várias regiões do Estado, deve ser desenvolvido individualmente, o que, à primeira vista, pode parecer mais complexo que os programas de reúso para fins agrícolas e para irrigação de áreas verdes.

Na tabela 2, são apresentados dados internacionais de distribuição do consumo de água na indústria por tipo de atividade. É importante destacar que os valores desta tabela podem estar desatualizados, tendo em vista que novas tecnologias indústrias são constantemente lançadas no mercado, servindo tão somente como valores de referência. 
Tabela 2 - Distribuição do consumo de água na indústria por atividades

\begin{tabular}{|c|c|c|c|}
\hline \multirow[b]{2}{*}{ Segmento Industrial } & \multicolumn{3}{|c|}{ Distribuição do Consumo de Água (\%) } \\
\hline & $\begin{array}{c}\text { Resfriamento } \\
\text { sem contato }\end{array}$ & $\begin{array}{c}\text { Processos e } \\
\text { Atividades Afins }\end{array}$ & $\begin{array}{c}\text { Uso Sanitário } \\
\text { e Outros }\end{array}$ \\
\hline Carne enlatada & 42 & 46 & 12 \\
\hline Abatimento e limpeza de aves & 12 & 77 & 12 \\
\hline Laticínios & 53 & 27 & 19 \\
\hline Frutas e vegetais enlatados & 19 & 67 & 13 \\
\hline Frutas e vegetais congelados & 19 & 72 & 8 \\
\hline Moagem de milho a úmido & 36 & 63 & 1 \\
\hline Açúcar de cana-de-açúcar & 30 & 69 & 1 \\
\hline Açúcar de beterraba & 31 & 67 & 2 \\
\hline Bebidas maltadas & 72 & 13 & 15 \\
\hline Indústria têxtil & 57 & 37 & 6 \\
\hline Serrarias & 58 & 36 & 6 \\
\hline Fábricas de celulose e papel & 18 & 80 & 1 \\
\hline Cloro e Álcalis & 85 & 14 & 1 \\
\hline Gases Industriais & 86 & 13 & 1 \\
\hline Pigmentos inorgânicos & 41 & 58 & 1 \\
\hline Produtos químicos inorgânicos & 83 & 16 & 1 \\
\hline Materiais plásticos e resinas & 93 & 7 & - \\
\hline Fibras de celulose sintéticas & 69 & 30 & 1 \\
\hline Tintas e pigmentos & 79 & 17 & 4 \\
\hline Produtos químicos orgânicos & 91 & 9 & 1 \\
\hline Fertilizantes nitrogenados & 92 & 8 & - \\
\hline Refinaria de petróleo & 95 & 5 & - \\
\hline Cimento & 82 & 17 & 1 \\
\hline Aço & 56 & 43 & 1 \\
\hline Fundição de ferro e aço & 34 & 58 & 8 \\
\hline Cobre primário & 52 & 46 & 2 \\
\hline Alumínio primário & 72 & 26 & 2 \\
\hline Automóveis & 28 & 69 & 3 \\
\hline
\end{tabular}

Fonte: VAN DER LEEDEN et al (1990) apud HESPANHOL e GONÇÃLVES (2005).

\subsubsection{Legislação sobre reúso de água no mundo}

Até o ano de 2000 não existiam normas européias para reúso de água de esgoto tratado, entretanto o Artigo $\mathrm{n}^{\circ} 12$ sobre as Diretivas para o Tratamento de esgotos (91/271/UE) é estabelecido que os esgotos tratados devem ser reaproveitados de maneira conveniente (TOMAZ, 2001 apud SILVA et al. 2003). 
A declaração de Paris, elaborada por ocasião da Conferência Internacional sobre Água e Desenvolvimento Sustentável, inicia por afirmar que os paises ali reunidos estão "convencidos de que a água doce é tão essencial para o desenvolvimento sustentável como para a vida e de que água doce possui dimensões sociais, econômicas e ambientais interdependentes complementares", concluindo claramente pela indicação da formulação de políticas que incluam "a necessidade de um compromisso constante, principalmente político, e de um amplo apoio da opinião pública, para garantir o desenvolvimento sustentável" (SILVA et al. 2003).

O Estado de Califórnia nos Estados Unidos tem um regulamento (Califórnia Code of Regulations, Titulo 22) para o reúso da água, a partir de esgoto após tratamento (TOMAZ, 2001 apud SILVA et al. 2003).

\subsubsection{Legislação sobre reúso de água no Brasil}

No Brasil, a partir da Constituição de 1988, a água passou a ser de domínio da União e dos Estados.

A Lei $n^{\circ}$ 9433/97 que instituiu a Política Nacional de Recursos Hídricos e criou o Sistema Nacional de Gerenciamento de Recursos Hídricos, prevê que a União e Estados podem cobrar sobre a água retirada dos rios e sobre o volume que for devolvido sem tratamento adequado (TOMAZ, 2001).

Em nível nacional, a cobrança pelo uso da água já é realizada e no estado de São Paulo, a cobrança foi aprovada pela Lei $n^{\circ} 12.183$ de 29 de dezembro de 2005, cuja regulamentação foi realizada através do Decreto $n^{\circ} 50.667$ de 30 de março de 2006. Embora as leis sejam recentes, é provável que as indústrias devam procurar meios que minimizem o consumo de água e o lançamento de efluentes buscando minimizar custos adicionais.

Dentre os instrumentos previstos pela Política Nacional de Recursos Hídricos, a cobrança pelo uso da água, materializando o princípio do usuário-pagador, talvez seja aquele que trará maior incentivo ao reúso de água como forma de minimização de passivo ambiental (FINK e SANTOS, 2003). 
Não só visando o aspecto econômico, mas ambiental e de Saúde Pública, é que alternativas devem ser buscados, na esperança de melhor utilizar os recursos hídricos (TOMAZ, 2001).

Apesar de nenhuma legislação até agora prever expressamente o reúso de água, é implícita sua disseminação. Quando falamos em falta de legislação para o reúso, não é propriamente para a utilização desta tecnologia, pois se observa que as leis, tanto da Política Nacional do Meio Ambiente, como da Política Nacional de Recursos Hídricos, estabelecem em seus princípios de execução, os mesmos princípios e filosofia de água (TOMAZ, 2001).

Quanto às leis sobre o tema reúso de água, vigentes no Brasil, pode-se destacar a lei $n^{\circ} 6938 / 81$ que institui a política nacional do meio ambiente que menciona o incentivo ao estudo e pesquisa de tecnologias orientadas para o uso racional e a proteção dos recursos ambientais. A lei n 9433/97 - Política Nacional de Recursos Hídricos - fixa os fundamentos, objetivos, diretrizes e instrumentos capazes de indicar a orientação publica no processo de gerenciamento dos recursos hídricos e estabelece entre os princípios de ações governamentais o incentivo ao estudo e pesquisa de tecnologias orientadas para o uso racional e a proteção dos recursos ambientais bem como a racionalização do uso da água, instituindo a cobrança pelo uso da mesma (outorga).

Sempre que água de boa qualidade não está disponível, ou é difícil de ser obtida, águas de menor valor, tais como esgotos domésticos, drenagem de irrigação e águas salobras são utilizadas. No entanto, nenhuma forma de ordenação política, institucional, legal ou regulatória orienta as atividades de reúso praticadas no Brasil. Como não existe experiência em reúso planejado e institucionalizado no país, é preciso implementar projetos pilotos, que deverão fornecer subsídios para o desenvolvimento de padrões e códigos de prática específicos. Uma vez concluída a fase experimental, as unidades pilotos deverão ser transformadas em sistemas de demonstração, objetivando treinamento, pesquisa e o desenvolvimento do setor. Legalmente, caberia à Agência Nacional de Águas - ANA, a competência para implementar e administrar uma política brasileira de reúso da água (HESPANHOL, 2002). 
A Agenda 21, capítulo 21, dedicou importância especial ao reúso de água, recomendando a implementação de políticas de gestão dirigidas para o uso e reciclagem de efluentes. Segundo Hespanhol (2002) embora não haja menção ao tema 'reúso', na política nacional de recursos hídricos, existe uma vontade política direcionada para esta questão. Segundo a Conferência Interparlamentar sobre o desenvolvimento do Meio Ambiente, realizada em Brasília em Dezembro de 1992, no parágrafo 64/B, há recomendação de esforços a nível nacional para institucionalizar a reciclagem e reúso sempre que possível, promovendo o tratamento e a disposição de esgotos de modo a não poluir o meio ambiente.

No estado de São Paulo, a Companhia de Saneamento Básico do Estado de São Paulo (SABESP), em conjunto com a Universidade de São Paulo (USP) e o Instituto de Pesquisa Tecnológica (IPT), desenvolveram o PURA (Programa de Uso Racional da Água), o qual foi efetivado pelo Governo do Estado de São Paulo, através do decreto $\mathrm{n}^{\circ} 45.805$ de 15 de Maio de 2001. Além de incentivar o uso racional e eficiente dos recursos hídricos, promove a busca por alternativas tecnológicas e implementação de programas de aproveitamento de água em regiões críticas. As ações aplicadas por este programa na Escola Toufic Jouliam reduziram o consumo per capita de 23 L/aluno.dia para 4.6 L/aluno.dia. Quanto ao uso de fontes alternativas, estas englobam a utilização de água da chuva, água subterrânea, águas residuárias, entre outras.

Atualmente, fala-se muito no reúso de água servida ou água resultante do processo de tratamento esgotos. Ocorre que, para a reutilização dessas águas, deve-se tomar uma série de providências e cuidados, bem como, atender as instruções contidas na Norma ABNT (Associação Brasileira de Normas Técnicas) 13.969 / 97 . A resolução $N^{\circ}$ 54, de 28 de novembro de 2005 estabelece modalidades, diretrizes e critérios gerais para a prática de reúso direto não potável de água, e dá outras providências. 


\subsubsection{Processos de tratamento}

A seleção de um sistema de tratamento apropriado é um dos principais desafios no fornecimento da água, que deve apresentar uma boa qualidade microbiológica e química. O sistema de tratamento deve remover os componentes físicos, químicos e microbiológicos indesejáveis e, em alguns casos, impedir o crescimento subseqüente de patógenos e de microrganismos causadores de doenças. Adicionalmente, a qualidade do alimento processado utilizando água de reúso deve ser pelo menos igual ou semelhante ao alimento processado usando a água da torneira (CASANI et al. 2004).

De acordo com Lazarova et al. (1999), apud Casani et al. (2004), a escolha do método de tratamento depende dos critérios para avaliar, se um determinado método ou processo é, viável técnica e economicamente, da segurança, da qualidade de água de processo, dos padrões existentes, das aplicações específicas de reúso, e da capacidade do tratamento do esgoto.

As tecnologias disponíveis para tratamento de águas residuárias e reúso são bastante numerosas, e podem ser consideradas pela exigência da qualidade do efluente a ser reutilizado, depende obviamente, da finalidade desse reúso; contudo, um aspecto de maior relevância a ser observado é a questão do monitoramento e controle de qualidade. A tabela 3 apresenta de forma sucinta os processos de tratamento mais apropriados para os sistemas de efluentes recuperados para subseqüente reúso. 
Tabela 3 - Descrição dos tipos de tratamento para esgoto recuperado e reúso.

\begin{tabular}{|c|c|c|}
\hline PROCESSO & DESCRIÇÃO & APLICAÇÃO \\
\hline \multicolumn{3}{|c|}{ Separação liquido / sólido } \\
\hline Sedimentação & $\begin{array}{l}\text { Sedimentação por gravidade de } \\
\text { substância particulada, flocos } \\
\text { químicos e precipitação. }\end{array}$ & $\begin{array}{l}\text { Remove partículas suspensas que } \\
\text { são maiores que } 30 \mu \mathrm{m} \text {. } \\
\text { Tipicamente usado como } \\
\text { tratamento primário e depois do } \\
\text { processo biológico secundário. }\end{array}$ \\
\hline Filtração & $\begin{array}{l}\text { Remove partículas através da } \\
\text { passagem de água por areia ou } \\
\text { outro meio poroso. }\end{array}$ & $\begin{array}{l}\text { Remoção de partículas } \\
\text { suspensas maiores de } \\
3 \mu \mathrm{m} \text {. Tipicamente usadas depois } \\
\text { da sedimentação (tratamento } \\
\text { convencional) ou seguido de } \\
\text { coagulação/floculação. }\end{array}$ \\
\hline \multicolumn{3}{|c|}{ Tratamento Biológico } \\
\hline $\begin{array}{l}\text { Tratamento Aeróbio } \\
\text { Biológico }\end{array}$ & $\begin{array}{l}\text { Metabolismo biológico de esgoto } \\
\text { através de microorganismos em } \\
\text { uma bacia de aeração ou processo } \\
\text { de biofilme. }\end{array}$ & $\begin{array}{l}\text { Remoção de matéria orgânica } \\
\text { suspensa e dissolvida do esgoto. }\end{array}$ \\
\hline Desinfecção & $\begin{array}{l}\text { Morte e/ou Inativação de } \\
\text { organismos patogênicos usando } \\
\text { produtos químicos oxidantes, calor } \\
\text { ou processos de separação física } \\
\text { (membranas), ou luz UV. }\end{array}$ & $\begin{array}{l}\text { Proteção da saúde pública através } \\
\text { da inativação, destrução e } \\
\text { remoção de organismos } \\
\text { patogênicos. }\end{array}$ \\
\hline \multicolumn{3}{|c|}{ Tratamento Avançado } \\
\hline Carvão Ativado & $\begin{array}{l}\text { Processos no quais os } \\
\text { contaminantes são fisicamente } \\
\text { absorvidos na superfície do carvão. }\end{array}$ & $\begin{array}{l}\text { Remoção de compostos orgânicos } \\
\text { hidrofóbicos. }\end{array}$ \\
\hline Aeração Forçada & $\begin{array}{l}\text { A água residuária é forçada a } \\
\text { passar a através de aeradores, } \\
\text { onde ar comprimido é injetado para } \\
\text { oxidar amônia e voláteis orgânicos. }\end{array}$ & $\begin{array}{l}\text { Remoção de amônia nitrogenada } \\
\text { e voláteis orgânicos. }\end{array}$ \\
\hline Troca lônica & $\begin{array}{l}\text { Troca iônica de íons entre resinas } \\
\text { de troca e água, usando um fluxo } \\
\text { através de reator. }\end{array}$ & $\begin{array}{l}\text { Abrandamento e remoção de } \\
\text { contaminantes iônicos } \\
\text { selecionados; eficaz na remoção } \\
\text { de cátions como cálcio, magnésio, } \\
\text { ferro e ânions, como o nitrato. }\end{array}$ \\
\hline $\begin{array}{l}\text { Coagulação e } \\
\text { Floculação Química }\end{array}$ & $\begin{array}{l}\text { Uso de sais de ferro ou alumínio, } \\
\text { polieletrólitos e/ou ozônio para } \\
\text { promover desestabilização das } \\
\text { partículas colóides do esgoto } \\
\text { recuperado e precipitado de fósforo. }\end{array}$ & $\begin{array}{l}\text { Formação de compostos de } \\
\text { fósforo precipitados e floculação } \\
\text { de partículas para remoção } \\
\text { através de sedimentação e } \\
\text { filtração. }\end{array}$ \\
\hline Tratamento com Cal & $\begin{array}{l}\text { Uso de óxido de hidróxido de cálcio } \\
\text { para precipitar em pH alto, vários } \\
\text { cátions e metais da água e da água } \\
\text { residuária. }\end{array}$ & $\begin{array}{l}\text { Usado para reduzir a disposição } \\
\text { de mineral, formando potencial de } \\
\text { água, e precipitação de fósforo. }\end{array}$ \\
\hline $\begin{array}{l}\text { Filtração de } \\
\text { Membrana }\end{array}$ & $\begin{array}{l}\text { Microfiltração, nanofiltração e } \\
\text { ultrafiltração. }\end{array}$ & $\begin{array}{l}\text { Remoção de colóides, cistos, } \\
\text { moléculas, e microrganismos da } \\
\text { água. }\end{array}$ \\
\hline Osmose Reversa & $\begin{array}{l}\text { Sistema de membrana para separar } \\
\text { íons de solução baseados no } \\
\text { diferencial da pressão osmótica } \\
\text { reversa. }\end{array}$ & $\begin{array}{l}\text { Remoção de sais dissolvidos e } \\
\text { íons minerais de solução, é } \\
\text { também eficiente na remoção de } \\
\text { partículas. }\end{array}$ \\
\hline
\end{tabular}

Fonte: Conservação e reúso da água em edificações, 2005. 


\subsubsection{Tecnologias de reúso de água}

A escolha do processo de tratamento de água residuária a ser adotado é de fundamental importância para o sucesso do empreendimento e, por isso, ela deve ser bastante criteriosa e fundamentada na boa caracterização do efluente a tratar, no conhecimento das técnicas de tratamentos existentes e nas necessidades e requisitos de qualidade da aplicação do reúso proposto. (METCALF \& EDDY, 2003).

Os métodos de tratamento nos quais a aplicação de forças físicas predomina são conhecidos como operações unitárias de tratamento e aqueles em que a remoção dos contaminantes é feita por ações químicas ou reações biológicas são conhecidos como processos unitários. Atualmente existem vários níveis de tratamento, conhecidos como tratamento preliminar, primário, secundário ou terciário. (METCALF\& EDDY, 2003)

Crook et al (1994), advertem que os tratamentos preliminares e primários, compostos por gradeamento, remoção de areia e sedimentação primária, são insuficientes para a produção de água de reúso, mesmo quando complementados por processos de floculação, controle de odor.

No gradeamento, os sólidos grosseiros, tais como objetos grandes, tecidos, madeiras e outros são removidos, principalmente porque podem causar danos aos equipamentos. Na etapa de tratamento, os matérias que flutuam e os materiais sedimentáveis encontrados nas águas residuárias são separados por flotação ou sedimentação, que nada mais são do que operações físicas. No caso de tratamento preliminar avançado, alguns produtos químicos podem ser adicionados para acelerar a remoção de sólidos suspensos e facilitar a sedimentação dos sólidos dissolvidos. (METCALF \& EDDY, 2003)

Após a coagulação e floculação, geralmente são empregados métodos gravitacionais como sedimentação, flotação e filtração. No processo biológico convencional, a sedimentação é aplicada em dois estágios, antes e depois da fase biológica. Com adição de coagulantes químicos, a sedimentação é fortemente acelerada. Mesmo assim, partículas finas e coloidais permanecem no efluente 
causando turbidez. Processos adicionais poderão ser necessários para poder melhorar a qualidade da água esperada. O método que melhor se aplica neste caso é a flotação por ar dissolvido, seguida de filtração. (PIMENTEL, 2003 apud MENDONÇA, 2004).

Os tratamentos terciários - filtração granular dos efluentes secundários, e os tratamentos avançados - coagulação e sedimentação, nitrificação, desnitrificação, remoção de fósforo, adsorção por carvão ativado e tratamentos por membranas filtrantes, são utilizados quando as águas de reúso exigem padrões de qualidade mais elevados (CROOK et al. 1994).

Cabe ressaltar que as tecnologias de tratamento foram apresentadas considerandose o tratamento de efluentes finais e não a opção de segregação dos efluentes, que é a opção mais adequada para a adoção da prática de reúso em indústrias do setor alimentício.

\subsubsection{Critérios e padrões de qualidade de água}

Devido à grande variedade de etapas nos processos de produção de alimentos, a água usada no processamento de alimentos pode conter uma mistura complexa de constituintes, havendo a necessidade de caracterização quando se considera a reciclagem, reúso, tratamento ou descarte. A adequação da água recuperada para o uso em todo o processo de produção de alimento é ditada pela qualidade da água requerida nesta operação, pela qualidade da água usada, pelo método da recuperação e da distribuição e a habilidade de recondicionar a água ao nível requerido. (CASANI et al. 2004).

A qualidade da água é definida em função de características físicas, químicas, microbiológicas e radioativas. Para cada tipo de aplicação, o grau de qualidade exigido pode variar significativamente. (SAUTCHUK, 2004)

O estabelecimento de padrões de qualidade de águas industriais deve levar em consideração aspectos inerentes à proteção do produto fabricado, como contaminações químicas e biológicas, manchas, corrosão, fatores ligados à proteção 
dos equipamentos industriais, bem com fatores voltados à eficiência dos processos, tais como formação de incrustações, depósitos, espumas, etc.

A qualidade exigida para o efluente a ser reutilizado depende, obviamente, da sua finalidade. Contudo, um aspecto de importante relevância a ser observado é a questão do monitoramento e controle da qualidade. Muitas aplicações exigem que um maior número de parâmetros sejam atendidos, de modo que sejam minimizados os riscos ao processo, produto ou sistema no qual esta água será utilizada.

Blum (2003), estabelece os seguintes critérios gerais norteadores de um programa de reúso quanto à qualidade da água produzida:

\section{a) Questão da saúde pública}

Relacionam-se, principalmente, a presença de organismos patogênicos, substâncias químicas orgânicas e inorgânicas. Os efeitos causados ao usuário em virtude destes agentes dependem de inúmeros fatores como o tempo de contato, a dose infectiva e a susceptibilidade do indivíduo infectado. Assim, os padrões de qualidade existentes fixam concentrações máximas de que permitidas no efluente em função do uso previsto. Quanto às concentrações de microrganismos patogênicos, os padrões consideram a condição mais desfavorável, isto é, maior nível de contato associado à menor dose infectiva e aos usuários mais sensíveis, crianças e idosos.

\section{b) Aceitação da água pelo usuário}

Este critério diz respeito às características organolépticas da água, em especial, cor e odor. É sabido que se a água de reúso possuir cor, o usuário pode considerá-la contaminada ou poluída.

\section{c) Preservação do ambiente}

Trata dos impactos positivos e negativos causados pela prática do reúso. Como exemplo, cabe salientar as alterações provocadas no solo e no entorno quando irrigado com efluentes compostos por altos teores de sais dissolvidos que podem levar a redução da permeabilidade do mesmo. A presença de nutrientes em excesso 
na água de reúso podem provocar o fenômeno da eutrofização em rios e lagos, caso o reúso praticado tenha a finalidade de garantir as vazões.

\section{d) Qualidade da fonte de água}

Influencia diretamente a eficácia do tratamento aplicado à água para reúso. Se o tratamento é destinado a efluentes domésticos e este receber, clandestinamente, a contribuição de esgotos industriais, a eficiência do sistema de tratamento e a qualidade do efluente ficarão comprometidas.

e) Adequação da qualidade ao uso pretendido; atendendo a padrões recomendados.

Este critério tem o objetivo de identificar e avaliar a interferência qualitativa das características da água para reúso. Isto significa dizer que as concentrações permitidas diferem em função do uso previsto.

Visto que a prática do reúso se tornou uma realidade e uma necessidade em muitos países, este tem sido orientado por diretrizes e normas. As restrições variam de um local para outro em função de fatores como as condições climáticas, acesso aos recursos hídricos, processos de tratamento, entre outros. 


\subsection{Aditivos alimentares}

Os aditivos alimentares têm sido usados por séculos; nossos ancestrais usaram sal para preservar carnes e peixes; adicionaram ervas e temperos para melhorar o sabor dos alimentos; preservaram frutas com açúcares e conservaram pepinos e outros vegetais com vinagre. Entretanto, com o advento da vida moderna, mais aditivos têm sido empregados, a cada ano. Os aditivos são usados para preservar os alimentos, melhorar o seu aspecto visual, seu sabor e odor, e estabilizar sua composição. Além disso, são empregados para aumentar o valor nutritivo e evitar a sua decomposição ou oxidação com o passar do tempo isto é, prolongar a vida dos alimentos processados (SCHVARTSMAN, 1982).

O uso dos aditivos alimentares possibilitou ao homem uma alimentação mais sadia, segura e higiênica. A ameaça do botulismo, comum em décadas passadas, foi praticamente banida. Hoje os alimentos podem ser guardados por longas datas, mesmo sem refrigeração. Com um rígido controle de toxidade, foi possível se estabelecer uma estreita relação entre a química e os alimentos: os sabores foram realçados, as aparências melhoraram e os micróbios morreram (SCHVARTSMAN, 1982).

Com o crescimento rápido da população mundial, e a grande demanda de alimentos, mais aditivos têm sido empregados. A existência de um grande número de produtos modernos tais como os de baixo valor calórico, comida pronta, salgadinhos embalados, não seria possível sem os aditivos.

O conceito de aditivo nos alimentos é bastante variável de país para país. Uma determinada substância poderá ser utilizada como aditivo por um país e ser proibida no país vizinho, acarretando problemas com relação à exportação (SCHVARTSMAN, 1982).

\subsubsection{Conceitos de aditivos alimentares}

Segundo Shreve (1980), os aditivos alimentares são as substancias que, combinadas aos alimentos pelo fabricante, provocam certas modificações, as quais 
envolvem a preservação do material, realçar sua coloração realce dos gostos e a estabilização, como que se puderam fazer assombrosos progressos no suprimento alimentar, além de se ter facilitado o trabalho na cozinha.

O aditivo alimentar é considerado pela legislação Brasileira como a substância intencionalmente adicionada ao alimento com a finalidade de conservar, intensificar ou modificar suas propriedades, desde que não prejudique seu valor nutritivo. A definição é de alguma forma, criticável, pois ao admitir a modificação das propriedades, mesmo não prejudicando seu valor nutritivo, induz ou favorece o engano. Essa situação é evidentemente contrária às regras educativas ou de comportamento frente à criança. (SCHVARTSMAN, 1982)

A definição da FAO/OMS (Organização Mundial de Saúde) é mais explícita e parece mais adequada, considerando aditivo como a substância não nutritiva adicionada intencionalmente ao alimento, geralmente em quantidades pequenas, para melhorar uma ou mais das seguintes características; aparência, aroma, sabor, textura e conservação (SCHVARTSMAN, 1982).

\subsubsection{Tipos de aditivos alimentares}

Existe um grande número de aditivos atualmente empregados e todos eles sofrem uma regulamentação federal no seu uso.

Schvartsman (1982) classifica os aditivos pelas funções desempenhadas nos alimentos, alterando algumas de suas características. Os tipos principais de aditivos estão relacionados a seguir:

\section{a) Acidulantes}

Comunicam ou intensificam o gosto ou sabor ácido aos alimentos processados.

\section{b) Antioxidantes}

São substâncias que retardam o aparecimento de alterações oxidativas nos alimentos, impedindo a interação com o oxigênio. 


\section{c) Aromatizantes e Flavorizantes}

São substâncias ou mistura de substâncias possuidoras de propriedades odoríferas ou sápidas capazes de conferir ou intensificar o aroma e/ou sabor dos alimentos. São classificados ainda em aromas naturais, aroma natural reforçado, aromas reconstituído, aromas imitação e aromas artificiais.

\section{d) Conservador}

São substâncias que possibilitam ou retardam a deterioração microbiana ou enzimática nos alimentos, ou seja, evitam processo de fermentação, acidificação e evidência de putrefação nos alimentos.

\section{e) Corantes}

São aquelas que conferem ou intensificam a cor dos alimentos. São ainda classificados em: corantes orgânicos naturais e corantes orgânicos sintéticos artificiais.

\section{f) Edulcorantes}

São substâncias orgânicas artificiais não glicidicas, capazes de conferir sabor doce aos alimentos, sendo também utilizados em produtos dietéticos.

\section{g) Estabilizantes}

Substâncias que favorecem e mantém as características físicas das emulsões e suspensões. Promovem uma interação homogênea de ingredientes como óleo e água, aumentam a viscosidade dos ingredientes e evitam a formação de cristais.

\section{h) Espessantes}

São substâncias capazes de aumentar a viscosidade de soluções, emulsões e suspensões, melhorando a textura e a consistência dos alimentos processados. 


\section{i) Umectantes}

Substâncias capazes de evitar a perda de água ou umidade nos alimentos pois, possuem propriedades hidroscópicas.

\section{j) Antiumectantes}

Substâncias capazes de reduzir as capacidades hidroscópicas dos alimentos. Impedem que as partículas se agrupem quanto em contato com a água.

\section{k) Espumiferos}

São substâncias que influem na tensão superficial dos alimentos, interferindo na produção de espumas com o propósito de gerar espuma estável.

\section{l) Antiespumíferos}

São substâncias que modificam a tensão superficial dos alimentos. Evitam a formação de espuma em alimentos durante o seu processamento

\section{m) Clarificantes}

São substâncias que retiram a turbidez dos alimentos.

- Edulcorantes;

- Geleificantes;

- Seqüestrantes ou quelantes. 


\subsection{Sistemas de gestão da qualidade na indústria de alimentos}

O conceito de qualidade de alimentos, na visão do consumidor, nada mais é do que a satisfação de características como sabor, aroma, aparência, embalagem, preço e disponibilidade. Muitas vezes é desconhecida a condição intrínseca de "segurança alimentar", quando se refere aos aspectos relacionados à influência deste alimento sobre a saúde do consumidor. Parece contra-senso, já que alimentos são consumidos para fornecer nutriente, ou seja, manter a saúde dos consumidores (WURLITZER, 2006).

Em indústrias, qualidade está relacionada à produtividade e segurança, e, no aspecto segurança relativa ao consumidor, além dos programas de qualidade voluntários, os sistemas de BPF (Boas Práticas de Fabricação) e APPCC (Análise de Perigos e Pontos Críticos de Controle) são exigidos pela legislação (WURLITZER, 2006).

\subsubsection{Definição de qualidade}

A concepção mais aceita de qualidade é aquela que a considera como o conjunto de características que diferenciam as unidades individuais de um produto e que têm importância na determinação do grau de aceitabilidade daquela unidade pelo comprador/consumidor. As características dos atributos de qualidade de produtos alimentícios dividem-se em três categorias principais: quantitativos, ocultos e sensoriais (BELLENZANI, 2004).

- Atributos quantitativos incluem características como: rendimento, peso líquido, integridade da embalagem, conteúdo de proteínas, vitaminas, minerais e lipídios, entre outras.

- Atributos ocultos incluem características como valor nutritivo, substâncias tóxicas, adulterantes e carga microbiana.

- Atributos sensoriais de qualidade englobam aqueles que são percebidos e julgados pelos usuários/consumidores, incluindo características como: cor, tamanho, forma, consistência, viscosidade, textura, sensação táctil oral, odor, sabor e defeitos. 
Crosby (1986), escreve de modo simples e define o termo como sendo "conformidade aos requisitos"; se um produto está conforme ele tem qualidade, se não esta conforme, não tem qualidade.

De acordo com Taylor (1987) apud Bellenzani (2004), qualidade significa, claramente, o atendimento das especificações do produto exigindo, portanto, grande esforço de inspeção do produto sobre os atributos, sendo esta de responsabilidade do próprio operador do processo de produção. Somente a partir da década de 1920 é que as atividades de inspeção e produção passaram a ser vistas como potencialmente separáveis.

Deming (1990), descreve a extremamente bem sucedida experiência japonesa, obtendo ganhos expressivos de produtividade por meio da redução da variabilidade, e, portanto das perdas e do re-trabalho nas atividades industriais. Para ele. Qualidade não é meramente conformidade às especificações, mas é satisfação do cliente em primeiro lugar.

Garvin (1992), após pesquisar várias definições de qualidade coletadas no ambiente corporativo e na literatura, classificou cinco abordagens distintas da qualidade, baseadas no produto, no usuário, na produção e no valor. Cada uma dessas abordagens apresenta aspectos diferentes deste complexo conceito - qualidade. A tabela 4 sintetiza a definição de qualidade, sob o prisma de cada uma dessas abordagens. 
Tabela 4 - Abordagens da qualidade

\begin{tabular}{|c|c|c|}
\hline ABORDAGENS & DEFINIÇÃO & FRASE \\
\hline Transcendental & $\begin{array}{l}\text { Qualidade é sinônimo de excelência } \\
\text { inata. } \\
\text { É absoluta e universalmente } \\
\text { reconhecível. } \\
\text { Dificuldade: pouca orientação prática }\end{array}$ & $\begin{array}{l}\text { "A qualidade não é nem } \\
\text { pensamento nem matéria, } \\
\text { mais uma terceira entidade } \\
\text { independente das duas... } \\
\text { Ainda que qualidade não } \\
\text { possa ser definida, sabe-se } \\
\text { que ela existe." (PIRSING, } \\
\text { 1974) }\end{array}$ \\
\hline Baseada no Produto & $\begin{array}{l}\text { Qualidade é uma variável precisa e } \\
\text { mensurável, oriunda dos atributos do } \\
\text { produto. } \\
\text { Corolários: melhor qualidade só com } \\
\text { maior custo. } \\
\text { Dificuldade: nem sempre existe uma } \\
\text { correspondência nítida entre os } \\
\text { atributos do produto e a qualidade. }\end{array}$ & $\begin{array}{l}\text { "Diferenças na qualidade } \\
\text { equivalem a diferenças na } \\
\text { quantidade de alguns } \\
\text { elementos ou atributos." } \\
\text { (ABBOTT, 1955) }\end{array}$ \\
\hline Baseada no Usuário & $\begin{array}{l}\text { Qualidade é uma variável subjetiva. } \\
\text { Produtos de melhor qualidade atendem } \\
\text { melhor os desejos do consumidor. } \\
\text { Dificuldade: agregar preferências e } \\
\text { distinguir atributos que maximizam a } \\
\text { satisfação. }\end{array}$ & $\begin{array}{l}\text { "A qualidade consiste na } \\
\text { capacidade de satisfazer } \\
\text { desejos...." (EDWARDS, } \\
\text { 1968) } \\
\text { "Qualidade é a satisfação das } \\
\text { necessidades do } \\
\text { consumidor"... } \\
\text { "Qualidade é adequação ao } \\
\text { uso." (JURAN, 1974) }\end{array}$ \\
\hline Baseado na Produção & $\begin{array}{l}\text { Qualidade é uma variável precisa e } \\
\text { mensurável, oriunda ao grau de } \\
\text { conformidade do planejado com o } \\
\text { executado. Esta abordagem dá ênfase } \\
\text { a ferramentas estatísticas (Controle de } \\
\text { processo) } \\
\text { Ponto Fraco: foco na eficiência, não na } \\
\text { eficácia. }\end{array}$ & $\begin{array}{l}\text { "Qualidade é a conformidade } \\
\text { ás especificações" } \\
\text { "Prevenir não conformidades } \\
\text { é mais barato que corrigir ou } \\
\text { refazer o trabalho." } \\
\text { (CROSBY, 1979) }\end{array}$ \\
\hline Baseado no Valor & $\begin{array}{l}\text { Abordagem de difícil explicação, pois } \\
\text { mistura dois conceitos distintos; } \\
\text { excelência e valor, destacando os } \\
\text { trade-off qualidade x preço. Esta } \\
\text { abordagem dá ênfase à Engenharia } \\
\text { Analise de Valor-EAV. }\end{array}$ & $\begin{array}{l}\text { "Qualidade é o grau de } \\
\text { excelência a um preço } \\
\text { aceitável." (BROH, 1974) }\end{array}$ \\
\hline
\end{tabular}

Fonte: Garvin (1992).

Juran (1992), diz que qualidade seria "adequação ao uso". Esta definição corresponderia ao atendimento das necessidades dos clientes e a ausência de defeitos.

Para Feigenbaun (1994), a qualidade pode ser definida como a combinação de características de produtos e serviços referentes a marketing, engenharia, produção 
e manutenção, através das quais produtos e serviços corresponderão às expectativas do cliente.

Quando se fala em qualidade para a indústria de alimentos, o aspecto segurança do produto é sempre um fator determinante, pois qualquer problema pode comprometer

a saúde do consumidor. É de se esperar, pois, que as boas empresas que atuam nesse ramo de atividade tenham algum sistema eficaz para exercer esse controle (FIGUEREIDO, 2001).

\subsubsection{Sistemas de qualidade}

Segundo Maranhão (2001), "sistema da qualidade é um conjunto de regras mínimas, com o objetivo de orientar cada parte da empresa para que execute corretamente, e no tempo devido, a sua tarefa, em harmonia com as outras, estando todas direcionadas para o objetivo comum da empresa: lucro".

Puri (1994), define que um sistema da qualidade engloba todos os processos que contribuem em conjunto para a obtenção da qualidade.

Cysne e Scharan (1993) definem que um sistema da qualidade é uma organização abrangendo todas as atividades que se relacionam direta ou indiretamente com a qualidade.

De acordo com a norma NBR ISO 9000:2000 - Fundamentos e vocabulário sistema de gestão da qualidade é um sistema para estabelecer política e objetivos e atingir estes objetivos para dirigir e controlar uma organização, no que diz respeito à qualidade.

Desta forma, ao se construir um sistema da qualidade dentro de uma empresa, isto é, ao se implementar e documentar atividades que serão de grande importância para a sua qualidade, deve-se dar importância especial para as relações entre as diversas atividades. Todos os departamentos da empresa devem, portanto, funcionar coordenados e de forma integrada, além de estarem comprometidos com os objetivos comuns da organização. 
Ao se implantar um sistema da qualidade, é necessário desenvolver estratégias para a sobrevivência e a prosperidade, utilizando criatividade para a diferenciação, redução de custos e aumento da qualidade, baseando-se em motivação e conhecimento dos colaboradores. (BELLENZANI, 2004).

\subsubsection{Implementação de sistemas de qualidade}

A implementação de sistemas da qualidade pode ser feita por vários caminhos. Atualmente, são encontrados processos de organização de empresas rumo à qualidade que diferem em sua filosofia e em seus métodos, mas todos têm as mesmas bases, sem as quais nenhum sistema da qualidade é bem sucedido.

Como exemplo, pode-se citar o modelo de 14 pontos do Dr. Edwards Deming. Ele enfatiza uma mudança da mentalidade do setor administrativo da empresa, ressaltando a necessidade do comprometimento da administração e a necessidade de participação de todos os funcionários no sistema. Ele lembra, ainda, a necessidade da constância de propósitos para melhorias de produtos e serviços.

Crosby (1990), em seu modelo que também é constituído de 14 pontos, enfatiza um pouco mais o lado da conformidade às exigências e da prevenção de defeitos, sempre buscando minimizá-los o máximo possível. Porém, Crosby lembra também a necessidade do comprometimento da direção e de equipes de melhoria da qualidade.

Juram (1992) apud Bellenzani (2004), enfoca mais o lado da qualidade aos olhos do cliente. Juran propõe a trilogia planejamento da qualidade, controle da qualidade e melhoria da qualidade como o método adequado para a construção de um sistema da qualidade. Planejar o sistema de acordo com as necessidades dos clientes, controlá-lo para que seja eficiente e melhorá-lo sempre que possível é, em seu modelo, o caminho para o sucesso. 


\subsubsection{Padrões de qualidade na indústria de alimentos}

Os padrões de qualidade são normalmente estabelecidos por órgãos oficiais de fiscalização e têm o objetivo de proteger o consumidor e a própria indústria. Órgãos de fiscalização aqui se referem aos Nacionais, Estaduais, Municipais e aos Internacionais como o Codex Alimentarius.

Os padrões de qualidade podem ser de dois tipos, quanto à ação: Obrigatórios e Voluntários. Os padrões obrigatórios, como o próprio nome indica, são aqueles que a indústria é obrigada a atender em seu sistema de produção e, normalmente, estão relacionados com a segurança da saúde do consumidor. Padrões voluntários são aqueles que a indústria tem a escolha de seguir ou não, a seu critério. Contudo, a indústria fica obrigada a atendê-los se ela escolher adotá-los (CHAVES, 1998).

\subsubsection{O Codex Alimentarius}

O Codex Alimentarius é um Programa conjunto da Organização das Nações Unidas para a Agricultura e a Alimentação e da Organização Mundial da Saúde (OMS). Trata-se de um fórum internacional de normalização sobre alimentos, criado em 1962, e suas normas tem como finalidade proteger a saúde da população, assegurando práticas eqüitativas no comércio regional e internacional de alimentos, criando mecanismos internacionais dirigidos à remoção de barreiras tarifarias, fomentando e coordenando todos os trabalhos que se realizam em normalização. Alguns destes textos são muito gerais e outros muito específicos. Alguns contem requisitos detalhados sobre um alimento ou grupos de alimentos; permite aos países participar na formulação de normas alimentícias de uso internacional e contribuir para á elaboração de códigos de práticas de higiene para a elaboração de recomendações relativas ao cumprimento das normas, outros têm por objeto o funcionamento e a gestão de processos de produção ou o funcionamento de sistemas de regulamentação pública da inocuidade dos alimentos e a proteção dos consumidores.

Os benefícios para o comércio mundial de alimentos em constante aumento, devem contar com umas normas alimentarias uniformes que protejam os consumidores são 
evidentes. Nesse sentido, as normas têm se convertido em pontos de referência internacionais pelo que podem se avaliar as medidas e regulamentos alimentícios nacionais em concordância aos parâmetros jurídicos dos acordos da Organização Mundial do Comercio (OMC).

O programa fornece elementos aos paises para a incorporação das normas aprovadas pelo Codex Alimentarius em sua legislação, estabelecimento do sistema de informação sobre legislação em inocuidade de alimentos, organização da Rede Interamericana de Laboratórios de Análise de Alimentos, apoio à modernização dos sistemas de inspeção e controle de alimentos por meio de treinamentos em APPCC (Análise de Perigos e Pontos Críticos de Controle) e BPF (Boas Práticas de Fabricação), organização do sistema de informação para a vigilância epidemiológica das enfermidades e organização de programas de educação sanitária sobre a inocuidade de alimentos e participação da comunidade.

\subsubsection{Boas Práticas de Fabricação - BPF}

Na década de 1960, foi publicada nos EUA a primeira regulamentação de BPF, que foi direcionada a produtos alimentícios. Este documento estabelecia que fabricantes de alimentos deveriam assumir responsabilidade pela segurança do produto que fabricavam e adotar medidas concretas que embasassem a segurança do produto. Em seguida, as BPF foram adotadas em Canadá, Suécia e Inglaterra e no Brasil o conceito foi introduzido na década de 1970.

No Brasil são conhecidas por Boas Práticas de Fabricação (BPF), e mundialmente pela sigla GMP (Good Manufacturiing Practice).

As BPF são ferramentas da filosofia de sistema de garantia da qualidade, que consiste em estabelecer normas que padronizem e definam procedimentos e métodos que regulamentem a fabricação de alimentos nos aspectos de segurança do alimento.

O objetivo do BPF define requisitos essenciais de higiene e de boas práticas de elaboração para alimentos industrializados para o consumo humano. O programa 
introduz mudanças nos métodos de produção, no projeto e uso de equipamentos, edifícios e instalações. Implica também em mudanças comportamentais de todas as pessoas envolvidas na produção dos alimentos, além de alterações no sistema de gestão, já que passa a utilizar rotinas de inspeção e registros de controle documentados.

As BPF são consideradas parte do sistema de gerenciamento da segurança alimentar, devendo ser implantadas antes ou durante o desenvolvimento do sistema de APPCC.

Como exemplos dessas práticas podem ser citados os sistemas sanitários de ordenha mecânica em circuitos fechados, a filtração do ar, o fechamento hermético de embalagens, a ultrafiltração, a microfiltração, a nanofiltração, o armazenamento refrigerado ou congelamento, a adição de ingredientes como sal ou açúcar, os processos fermentativos, etc. Os funcionários devem seguir hábitos de higiene pessoal, estar em bom estado de saúde, lavar sempre as mãos, usar roupas e luvas apropriadas, não fumar nas áreas proibidas, nunca jogar pontas de cigarro no chão e não levar animais na fábrica. O programa inclui também uma ampla gama de dispositivos e procedimentos manuais ou automáticos, regulando atributos como temperatura, tempo, fluxo, pH, acidez, peso, etc. Inibição e destruição são práticas adotadas. Um técnico será o responsável pelo controle da manutenção do processo, sistemas de registro, documentação e desempenho do sistema de processamento.

Dentre as regras de BPF está o programa que prevê, através de ações corretivas, eliminar os focos de infestação de plagas. É um conjunto de ações simultâneas que visam a implementação de métodos cíclicos de educação, sanitização, intervenções químicas e barreiras físicas, com o objetivo de preservar o meio ambiente e reduzir a probabilidade de riscos de contaminações dos alimentos, matérias-primas e insumo, por produtos químicos.

Para estabelecer um programa de BPF é necessário, segundo SBCTA (1995) apud Spexoto (2003) primeiramente estabelecer condições prévias que permitirão sua correta implantação, continuidade e aperfeiçoamento: 
- Comprometimento da direção

- Designação do técnico responsável

- Análise das práticas de manufatura da empresa

- Correções físicas em edificações, instalações e equipamentos

- Definição das operações sanitárias e documentação

- Treinamentos de funcionários

- Auditoria do programa

Outras vantagens do estabelecimento de um programa de BPF, segundo VIALTA et al (2002), são a melhoria do ambiente de trabalho e motivação aos funcionários, devido ao atendimento de requisitos da legislação:

- Portaria N³26/97 do Ministério da Saúde e

- Portaria N 368/97 do Ministério da Agricultura

\subsubsection{Controle estatístico de qualidade}

Refere-se à aplicação de técnicas estatísticas apropriadas para análise de desempenho de processo e auxílio em tomadas de decisão. Busca utilizar métodos estatísticos para prevenir falhas por meio da avaliação de fatos ocorridos e quantificação de riscos (probabilidade) de se evitar desvios em um processo de produção. Pode envolver o nível gerencial, de supervisão e operacional. Variabilidade é um fenômeno comum nos itens provenientes de um processo industrial. Ela ocorre tanto em indicadores de desempenho de operações do processo, como seu rendimento, quanto nos indicadores de qualidade dos itens produzidos, mesmo estando o processo sob controle. A estatística dispõe de técnicas que viabilizam a coleta, o processamento (análise), a disposição dos dados, além daquelas inferências que auxiliam na tomada de decisão. Os delineamentos de experimentos, ensaios e levantamentos e a conseqüente análise dos dados são exemplos de métodos a serem usados no Controle Estatístico de Processos (CEP). O estudo das distribuições de freqüência dos dados do processo é útil no estabelecimento de planos de amostragem para inspeção de desempenho do processo ou de qualidade dos produtos. As cartas de controle são ferramentas de grande utilidade em controle estatístico de processo. São várias as técnicas estatísticas que vêm sendo utilizadas em controle de qualidade, tais como: análise 
de variância, teste de contrastes e de médias; análise de regressão; amostragem estatística; cartas de controle, entre outras (CHAVES. 1998).

$\mathrm{Na}$ abordagem da Qualidade vale a pena destacar algumas ferramentas estatísticas que servem para a gestão de uma boa administração:

\section{a) Estratificação}

Processo de classificar os dados em subgrupos baseados em características ou categorias. Estratificar é dividir as informações (dados) em grupos (ou estratos), constituindo-se numa ferramenta para a busca das causas ou origens de um problema. Os dados devem ser agrupados por tempo, local, tipo, sintoma e outros fatores. A estratificação é fundamental para a construção do Gráfico de Pareto.

\section{b) Folha de verificação}

Uma folha de verificação é um formulário em que os itens a serem verificados já vêm impressos, de forma que os dados podem ser coletados e registrados de forma fácil e concisa. Se dados precisam ser coletados é importante tornar o propósito claro e ter dados que reflitam claramente os fatos. Em situações reais é necessário que os dados sejam coletados de forma simples, em formulário de fácil utilização.

\section{c) Diagrama de causa e efeito}

Mostra a relação entre um conjunto de causas que provoca um ou mais efeitos. É uma forma organizada de correlacionar o efeito com suas causas, agrupando-as em "famílias de causas", tais como: matéria-prima, máquina, mão de obra, medida, método e meio ambiente. O Diagrama de Causa e Efeito proporciona ao gerente melhor entendimento de que ele tem autoridade sobre as causas e responsabilidade sobre os efeitos (resultados) de um processo. É também conhecido como Diagrama de Ishikawa ou de Espinha de Peixe.

\section{d) Gráfico de Pareto}

Gráfico de barras que ordena as freqüências das ocorrências, da maior para a menor, permitindo a priorização dos problemas. Mostra ainda a curva de 
percentagens acumuladas. Sua maior utilidade é a de permitir uma fácil visualização e identificação das causas ou problemas mais importantes, possibilitando a concentração de esforços sobre os mesmos.

\section{e) Histograma}

Gráfico de barras que representa a distribuição de freqüência de uma população, de uma amostra ou de um universo de dados..

\section{f) Diagrama de dispersão}

Gráfico utilizado para a visualização do tipo de relacionamento existente entre duas variáveis. Estas variáveis podem ser duas causas de um processo, uma causa e um efeito do processo ou dois efeitos do processo. É uma das Sete Ferramentas do Controle da Qualidade.

\section{g) Gráfico de controle}

Representação gráfica de uma característica do processo que registra os valores estatísticos dessa característica em função do número da amostra ou de outra indicação do tempo e um ou dois limites de controle. Ele informa se o processo está ou não sob controle estatístico. É útil para monitoramento da variabilidade e para a avaliação da estabilidade de um processo, sendo também muito efetivo em diversas etapas dos Ciclos PDCA para manter e para melhorar. Existem dois tipos de gráficos de controle: Gráfico de Controle para Variáveis e Gráfico de Controle para Atributos.

Não comumente usadas, as ferramentas descritas abaixo apontam para uma preocupação constante do setor com relação a sua Qualidade, afim de atingir ganhos mais significativos tanto na produtividade quanto na qualidade em si.

h) QFD: (Quality Function Deployment significa Desdobramento da Função Qualidade)

É um método para desenvolvimento de uma ampla variedade de produtos e serviços, buscando identificar os desejos e as necessidades dos clientes para criar produtos que atendam às exigências dos clientes. O QFD tem como objetivo gerenciar o processo de desenvolvimento de modo a manter o foco sempre voltado 
para o atendimento das necessidades dos clientes. Esse gerenciamento é feito através da identificação e desdobramento das variáveis que compõem o desenvolvimento do produto, através de tabelas, matrizes e procedimentos de extração, relação e conversão.

i) FMEA: (Failure Mode and Effects Analysis; significa Análise dos Modos de Falhas e seus Efeitos).

Método de análise de produtos e processos que permite uma avaliação sistemática e padronizada de possíveis falhas, estabelecendo suas conseqüências e orientando a adoção de medidas corretivas (preventivas). Fornece pistas para a execução de melhorias nos sistemas, mediante a descoberta de pontos problemáticos. O ponto problemático é enfocado a partir da causa, raciocinando na direção do efeito (falhaproblema). Seus objetivos são: - identificar as falhas críticas em cada componente, suas causas e conseqüências; - hierarquizar as falhas e analisar a confiabilidade do sistema.

j) FTA: (Fault Tree Analysis significa Análise da Árvore de Falhas)

Método de análise de produtos e processos que permite uma avaliação sistemática e padronizada de possíveis falhas, estabelecendo suas conseqüências e orientando a adoção de medidas corretivas (preventivas). O objetivo é identificar as causas primárias das falhas; a elaboração de uma relação lógica entre falhas primárias e falha final do produto; e análise da confiabilidade do sistema. Na FTA parte-se do efeito e chega-se à causa.

\section{k) Seis Sigma:}

Seis Sigma é hoje o programa mais importante de melhoria de processos e redução de custos. Trata-se de uma estratégia gerencial de mudanças para acelerar o aprimoramento em processos, produtos e serviços. O conceito Seis Sigma é uma nova forma de medir a eficiência dos processos internos das empresas. Quando um processo tem qualidade Seis Sigma a probabilidade de produzir defeitos (itens fora de especificação) é extremamente baixa. Isto é conseqüência do emprego de toda uma cultura de estratégias, ferramentas e metodologias estatísticas para melhorar 0 processo de análise e tomada de decisão das empresas. 


\subsubsection{O sistema APPCC}

Segundo PARVIS (2002), a indústria de alimentos já vem utilizando a ferramenta APPCC com sucesso para prevenir a contaminação dos produtos, contudo o setor de fornecimento de alimentação ainda não esta familiarizado com esta ferramenta.

O sistema APPCC parece ter se inspirado nas teorias sugeridas pelo Dr. Edwards Deming e outros, as quais começaram a transformar a qualidade nas linhas de produção especialmente as de veículos na década de 1950 no Japão, e abriram passagem para o desenvolvimento de sistemas de Gestão da Qualidade Total (GQT), que tinham como objetivo melhorar a qualidade das manufaturas ao mesmo tempo em que reduziam os seus custos de produção.

\subsubsection{História do APPCC}

Este sistema foi utilizado pela primeira vez, nos ano 1960, pela Pillsburg Company, junto com a NASA (National Aeronautics and Space Administration) e o U.S Army Laboratories em Natick, com o objetivo de desenvolver um programa de qualidade que, utilizando algumas técnicas, desenvolvesse o fornecimento de alimentos para os astronautas da NASA. Sendo apresentado ao público pela primeira vez em 1971, durante uma conferência nacional para proteção de alimentos, realizada nos Estados Unidos (ATHAYDE, 1999).

Em 1960, no âmbito da Organização das Nações Unidas (ONU) e por impulso da Áustria, foi criada uma comissão para elaboração de um código alimentar regional, denominado Codex Alimentarius Europeu.

Em 1961 começou a sentir-se a necessidade de alargamento internacional - o que foi formalizado em 1963, entre a OMS (Organização Mundial da Saúde) e FAO (Organização das Nações Unidas para Alimentação e Agricultura), com a Comissão do Codex Alimentarius para o estudo e publicação de guias e normas de segurança alimentar. 
Em 1967 a Food and Drug Administration (FDA) e a indústria iniciaram um processo de autocontrole para todo o processamento de alimentos.

Em 1988 surgem os relatórios da Comissão Internacional de Especificações Microbiológicas de Alimentos (ICMFS), e em 1991 surgiu o Guia para a aplicação do sistema APPCC elaborado pela comissão Codex Alimentarius revisto em 1993 e 1999.

Em 1993 o Conselho da União Européia publicou a Diretiva 93/43/CE relativa à higiene dos produtos alimentares, que levou obrigatoriamente à transposição para o direito nacional de cada estado membro.

Em 1995 todas as companhias de alimentos nos Estados Unidos foram requisitadas a ter um sistema efetivo de APPCC, este é foi o resultado da diretriz relacionada a Higiene de Produtos Alimentícios (EEC diretriz 96/46) que foi passada em 14 de junho de 1993 pelo Conselho da Europa.

A partir de 14 de dezembro de 1995, todas as empresas de alimentos da União Européia devem ter implementado um sistema de APPCC.

Em 1998 foi publicada a norma dinamarquesa DS3027 relativa à Segurança Alimentar através do APPCC. Requisito importante para as empresas produtoras de gêneros alimentícios e seus fornecedores.

\subsubsection{Conceitos fundamentais sobre o sistema APPCC}

O sistema APPCC é um método embasado na aplicação de princípios técnicos e científicos de prevenção, que tem por finalidade garantir a inocuidade dos processos de produção, manipulação, transporte, e distribuição dos alimentos. Esse conceito cobre todos os fatores que possam afetar a segurança do alimento (ATHAYDE, 1999). 
No Brasil o termo HACCP foi substituído pela sigla APPCC e nesse trabalho essas duas nomenclaturas serão adotadas como sinônimos no que se refere à analise de perigos e pontos críticos de controle.

Apesar do APPCC, ser uma ferramenta desenvolvida originalmente pelo setor privado para garantir a segurança do produto, atualmente, está sendo introduzida na legislação de vários países A legislação em segurança do alimento é geralmente entendida como um conjunto de procedimentos, diretrizes e regulamentos elaborados pelas autoridades, direcionados para a proteção da saúde pública.

O sistema APPCC foi internacionalmente aceito como uma importante ferramenta para a segurança do alimento por organismos internacionais como:

- OMC (Organização Mundial do Comércio)

- FAO (Food and Agriculture Organization)

- OMS (Organização Mundial da Saúde)

- MERCOSUL (Mercado Comum do Sul).

O Sistema APPCC é exigido pela:

- CE - Comunidade Européia

- EUA - através das agências: FDA (Food and Drugs Administration) e USDA (United States Department of Agriculture).

O Sistema APPCC é parte integrante de outros sistemas de certificação Européia de alimentos:

- BRC: British Retail Consortium - para exportações ao Reino Unido

- EUREPGAP: Euro-Retailer Produce Working Group - para exportações de frutas e vegetais para Europa

- PDV: Product Board Animal Feed - para exportação de produtos a serem utilizados como ração de uso animal 
No Brasil o APPCC é um requisito legal, pois existem Legislações do Ministério da Saúde e Agricultura Pecuária e Abastecimento que tornam sua implantação obrigatória:

- Portaria N 1.428 do Ministério da Saúde de 26/11/1993 e,

- Portaria N 46 do Ministério de Agricultura de 10/02/1998.

- NBR 14900:2002

Apesar de todas as ações adotadas pelo Governo, e mesmo pela iniciativa privada, - Brasil ainda se ressente com a ausência de número suficiente de técnicos capazes de assessorar a implantação do Sistema na indústria. Também é marcante a falta de conhecimento da APPCC pelos empresários e pelos técnicos da grande maioria das empresas de médio porte e pelas quase totalidades das empresas do pequeno porte, além das microempresas.

sistema APPCC utiliza conceitos próprios, com as seguintes terminologias (BRYAN, 1993 apud SPEXOTO, 2003):

- Perigo: contaminação inaceitável de natureza biológica, química ou física que leva o alimento a tornar-se impróprio para o consumo;

- Risco: estimativa da probabilidade de ocorrência de um perigo;

- Ponto Crítico de Controle - PCC: etapa da produção onde são aplicadas medidas preventivas para manter determinado ponto sob controle, com o objetivo de eliminar, prevenir ou reduzir riscos que possam causar algum problema à saúde do consumidor. O PCC, segundo Silva (1999), pode ser de diferentes tipos, de acordo com o controle exercido sob o perigo, sendo PCCe, quando os perigos são eliminados, PCCp, no qual o perigo é prevenido, e PCCr, no qual os perigos são reduzidos, minimizados ou retardados a níveis significativos;

- Limite Crítico: valor ou atributo estabelecido para cada variável relacionado a um ponto crítico que, quando não atendido, pode colocar em risco a saúde do consumidor. Afixação dos limites críticos pode ser obtida de fontes como 
guias e padrões de legislação, literatura, experiência prática, levantamento prévio de dados, normas internas de cada empresa, entre outras fontes;

- Ação Corretiva: ações imediatas e específicas a serem tomadas sempre que os limites críticos não são atingidos;

- Verificação: é o uso de testes suplementares ou revisão dos registros de monitoramento para determinar se o método APPCC está funcionando como planejado;

- Árvore Decisória: seqüência lógica para determinar se uma matéria-prima, ingrediente ou etapa de processo, para um determinado perigo, constitui-se em um PCC.

\subsubsection{Os pré-requisitos do sistema APPCC}

Programas pré-requisitos representam a primeira etapa na obtenção de qualidade assegurada para estabelecimentos que processam e/ou manipulam alimentos. Podem ser definidos como procedimentos ou etapas universais que controlam condições operacionais dentro de uma indústria alimentícia, permitindo a criação de condições ambientais favoráveis à produção de um alimento seguro. Eles incluem elementos que são freqüentemente descritos como Boas Práticas de Fabricação como, por exemplo, limpeza e sanitização, higiene pessoal e do ambiente fabril, projeto higiênico-sanitário da planta e manutenção preventiva. Essas condições estão bem estabelecidas e têm sido empregadas há bastante tempo pelo setor alimentício, de tal forma que qualquer estabelecimento processador de alimentos trabalha de acordo com um destes itens.

\subsubsection{Princípios básicos do sistema APPCC no reúso de águas}

Segundo ATHAYDE (1999), existem sete princípios básicos que devem ser seguidos para a implementação do APPCC:

1) Identificar os perigos potenciais;

2) Determinar os PCCs, de acordo com os perigos levantados (através da árvore decisória); 
3) Estabelecer os Limites Críticos para as medidas preventivas associadas com cada PCC;

4) Estabelecer uma rotina de monitoramento em função dos limites críticos;

5) Estabelecer ações corretivas para serem implementadas, caso os limites críticos sejam excedidos;

6) Estabelecer um efetivo sistema de anotações para o programa;

7) Estabelecer um sistema de verificação para dar continuidade ao APPCC.

Os princípios estão detalhados de acordo com os seus objetivos na tabela 5 .

Tabela 5 - Descrição dos princípios do sistema de análise de perigos e pontos críticos de controle e seus respectivos objetivos

\begin{tabular}{ll}
\hline \multicolumn{1}{c}{ PRINCÍPIOS } & \multicolumn{1}{c}{ OBJETIVOS } \\
\hline 1. Análise de perigos e medidas preventivas. & Definir: O que é perigo (biológico, químico e \\
& físico) / Como conduzir uma análise de perigos / \\
& Como identificar perigos significativos / O que \\
& são medidas preventivas / Como identificar \\
& medidas preventivas. \\
\hline 2. Identificação dos pontos críticos de controle. & Identificar e caracterizar os PCCs (considerando \\
& a relação direta entre perigo significativo e PCC) \\
& / Tomar esta decisão usando a árvore decisória \\
& ou respondendo as perguntas. \\
\hline
\end{tabular}

3. Estabelecimento de limites críticos para a Estabelecer como se define um limite crítico / medida preventiva associada a cada PCC. Quantificar o próprio limite crítico, em função do PCC / Obter informações sobre o limite crítico.

4. Estabelecimento da necessidade de Definir o que é monitorar, o que monitorar e monitoramento do PCC e dos procedimentos porque / Definir quais métodos e equipamentos para utilização dos resultados obtidos, para são usados para monitorar o limite crítico / ajuste do processo e manutenção do controle. Definir a freqüência de monitoramento e o responsável pelo monitoramento.

5. Implementação de ações corretivas, Quando Definir a ação corretiva / Estabelecer da ocorrência de desvio de um limite crítico. procedimento para ação corretiva / Manter registro adequado das ações corretivas.

6. Estabelecimento e manutenção dos registros Determinar quais os registros são necessários dos procedimentos de documentação do sistema para o cumprimento do plano APPCC / Quando APPCC. monitorar as informações registradas / Como os registros devem ser usados.

7. Estabelecimento dos procedimentos para a Definir o termo de verificação / Quais as funções verificação do correto funcionamento do sistema de verificação do plano APPCC. APPCC.

Fonte: Adaptado de Oliveira (2002) apud SPEXOTO (2003).

O plano APPCC a ser aplicado no reúso de água de processo na indústria de alimento requer que alguns passos preliminares sejam realizados antes da implementação dos sete princípios. O propósito dos passos preliminares é fornecer o máximo de informação possível para a equipe APPCC com respeito à água usada previamente e seu uso. Um mapeamento microbiológico da água de processo nos 
diferentes estágios da cadeia de produção de alimentos será de muita utilidade na implementação do APPCC. O mapeamento microbiológico é uma ferramenta útil na avaliação do potencial de reúso e na identificação dos perigos microbiológicos (o primeiro dos sete princípios do sistema APPCC). O Sistema APPCC para ser aplicado no reúso de água na indústria de alimento requer os passos preliminares, mostrados na figura 3 .

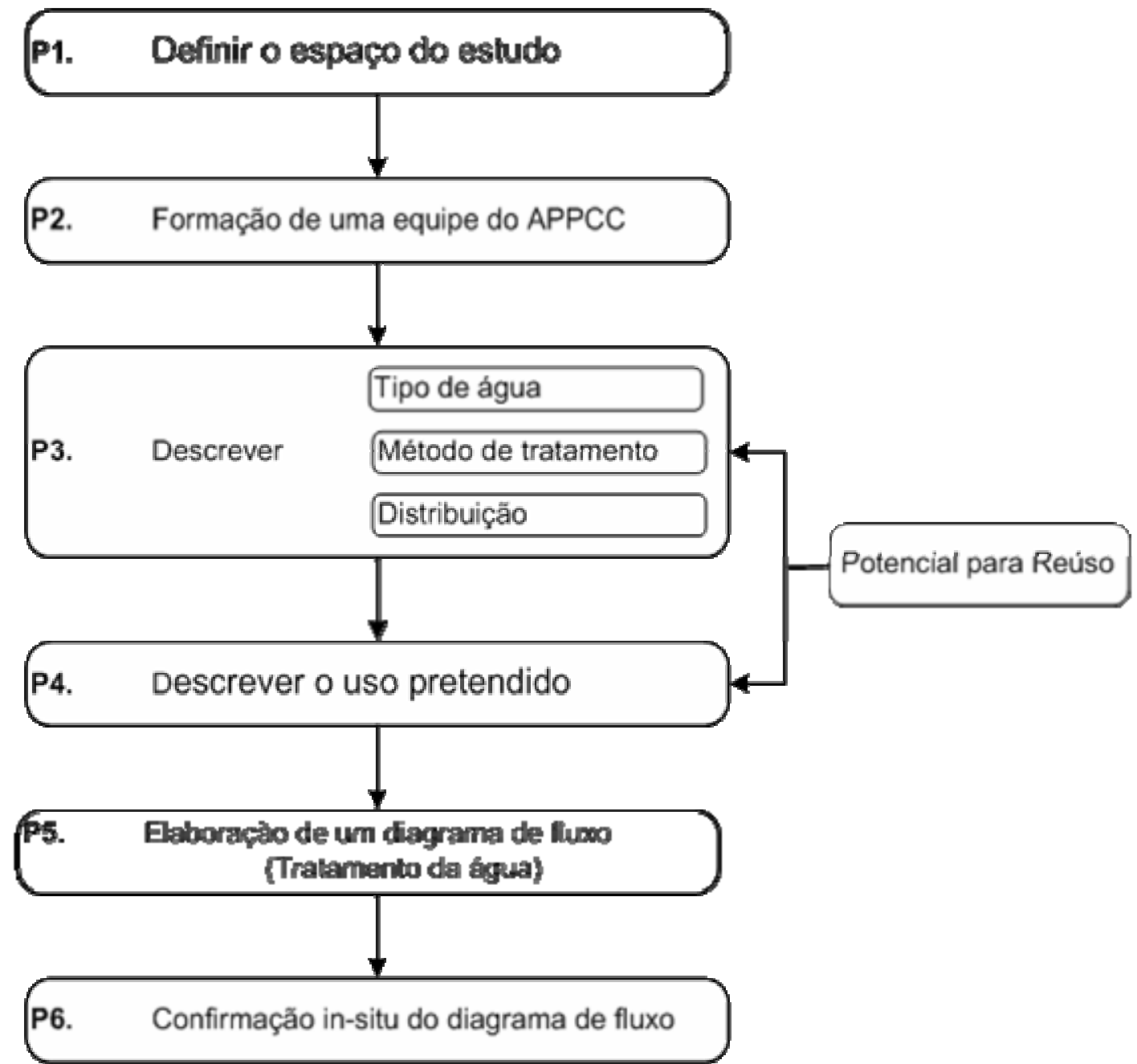

Figura 3 - Passos preliminares para a aplicação do reúso de água na indústria de alimentos.

Fonte: Cassani e Knochel, (2002)

Após os passos preliminares, na figura 4 é possível avaliar a confiabilidade dos possíveis reúsos e tratamentos da água de processo usada previamente. Deve ser claramente estabelecido se a água recuperada pode ser reusada novamente em algum outro processo da planta ou se um novo tratamento é necessário para seu reúso. 


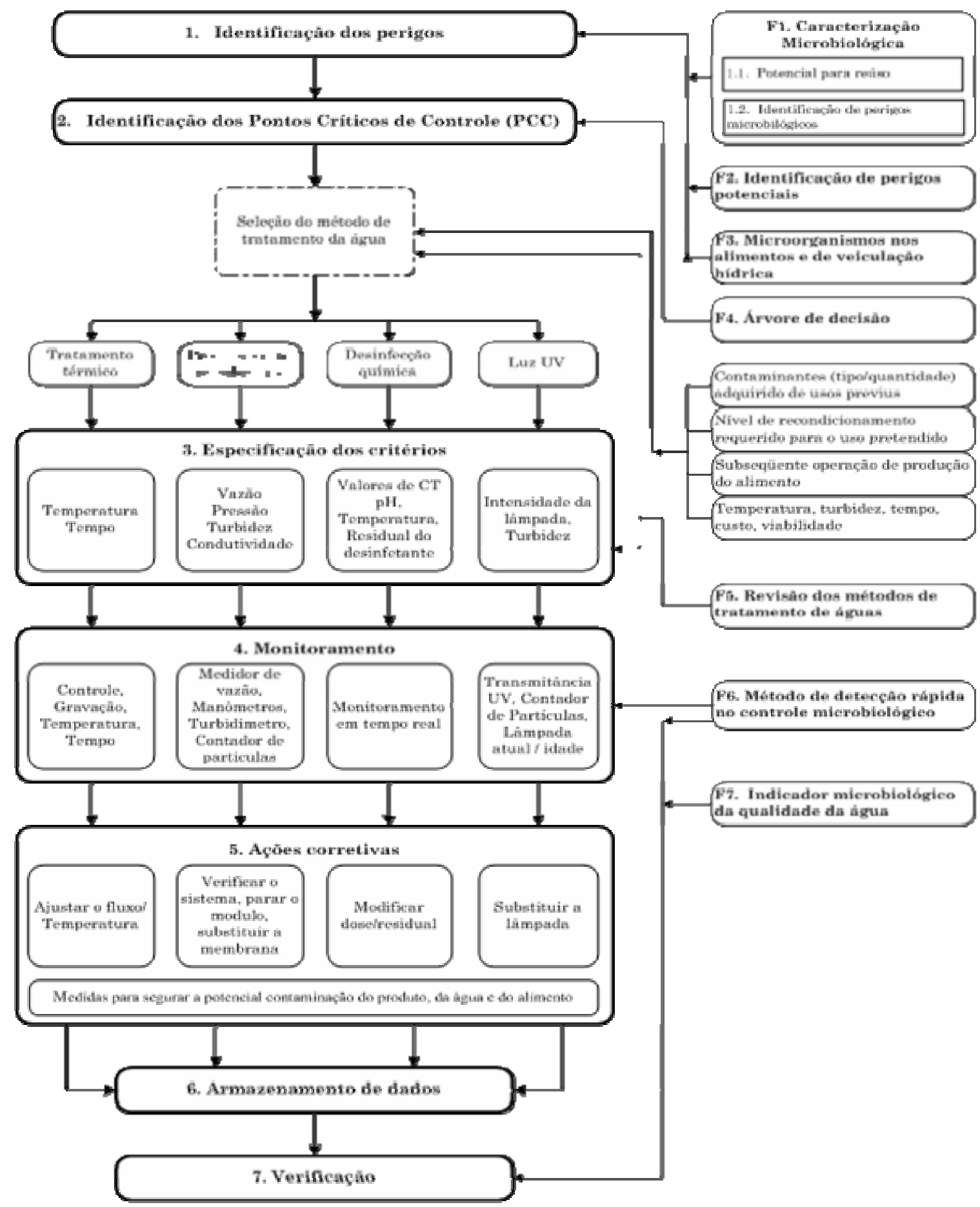

Figura 4 - Sete princípios do APPCC para a aplicação do reúso de água na indústria de alimentos.

Fonte: Cassani e Knochel, (2002)

A aplicação dos sete princípios do sistema APPCC precisa de 12 etapas para sua implementação, na figura 5 se identificam na seqüência lógica para a aplicação do sistema de APPCC: 
1. Formação de uma equipe de APPCC

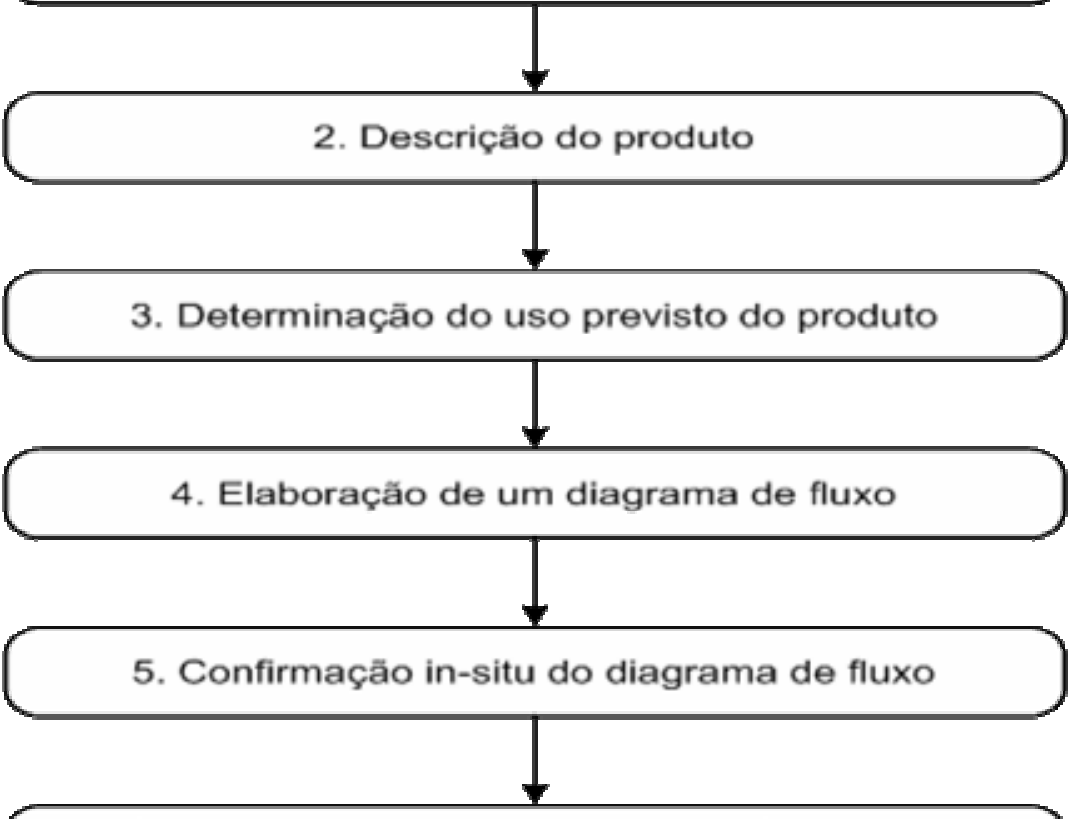

6. Compilação de uma lista dos possiveis perigos relacionados com cada fase, realização de um análise de perigos e exame das medidas para controlar os perigos identificados

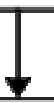

7. Determinação dos pontos críticos de controle

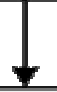

8. Estabelecimento de limites críticos para cada PCC

9. Estabelecimento de um sistema de vigilância para cada PCC

10. Estabelecimento de medidas corretivas

11. Estabelecimento de procedimentos de comprobação

12. Estabelecimento de um sistema de documentaçăo e registro

Figura 5 - Etapas para a implementação do sistema APPCC

Fonte: Figuereido (2001) 
O Codex Alimentarius recomenda a seguinte seqüência para implementação do sistema de HACCP:

\section{Formação da equipe de HACCP}

A equipe deve ter uma formação multidisciplinar. As pessoas devem estar familiarizadas com os produtos e seus métodos de elaboração. As pessoas integrantes da equipe devem ter poder de convencimento, liderança e capacidade de multiplicação dos conceitos. O líder da equipe deve ter treinamento e habilidade suficiente em APPCC. O escopo do estudo deve ser definido, sabendo-se quais etapas da cadeia produtiva devem ser envolvidas.

\section{Descrição do produto}

Uma detalhada descrição do produto deve ser feita, incluindo sua composição química e física, o tipo de embalagem, o transporte utilizado na distribuição, as condições de armazenagem e o tempo de vida útil.

\section{Identificação do uso}

Deve-se identificar qual o público-alvo do produto e saber se faz parte de um segmento particular da população (bebês, idosos, enfermos, adultos, etc.).

\section{Construção do diagrama de fluxo}

Deve-se resumir o fluxo de processo em um diagrama simplificado, que forneça um esboço do processo e realce a localização dos perigos potenciais identificados. É importante não negligenciar nenhuma etapa que possa afetar a segurança do alimento.

\section{Confirmação no local das etapas descritas no fluxograma}

Uma vez estabelecido o diagrama operacional, deve-se efetuar a inspeção no local, verificando a concordância das operações descritas com o que foi representado. 
Esta etapa irá assegurar que os principais passos do processo terão sido identificados e possibilitar os ajustes necessários.

6. Listar todos os perigos, analisar os riscos e considerar os controles necessários.

Todos os perigos em potencial, relacionados a cada etapa do processo, devem ser identificados com base na experiência dos membros da equipe e nas informações de saúde pública sobre o produto. A análise dos riscos deverá ser feita considerando os seguintes fatores:

- Probabilidade de ocorrência do perigo e sua severidade em relação aos efeitos adversos à saúde;

- Evolução qualitativa e quantitativa da presença do perigo;

- Capacidade de multiplicação e sobrevivência dos microorganismos; e

- Produção ou permanência nos alimentos de toxinas, agentes químicos ou físicos.

Quaisquer medidas de controle existentes ou que poderiam ser aplicadas devem ser listadas. Mais de uma medida de controle pode ser necessária para controlar um perigo e mais de um perigo pode ser controlado por uma mesma medida de controle.

\section{Determinar os pontos críticos de controle (PCC)}

Um PCC é uma etapa na qual um controle pode ser aplicado, sendo essencial prevenir ou eliminar um perigo relativo à segurança dos alimentos, reduzi-lo ou mantê-lo em nível aceitável. Identificar os PCCs no estudo de APPCC pode ser facilitado utilizando-se uma árvore decisória, que consiste em se fazer uma série de perguntas para cada etapa de elaboração do produto. Muitos pontos críticos de controle sugerem uma análise de riscos irreal, enquanto poucos PCCs identificados indicam que podem existir riscos que não foram considerados. Por isso, a etapa de identificação dos PCCs é um aspecto crítico do estudo de APPCC. Note-se que existem algumas partes do processo ou equipamento que a empresa quer monitorar, mas não são PCCs levantados pela APPCC. Estes pontos podem ser identificados como pontos de controle (PCs) da qualidade e são controlados para evitar um desvio nos PCCs, que protegem a saúde pública. 


\section{Estabelecer limites críticos para cada PCC}

Os limites críticos são aqueles que separam os produtos aceitáveis dos inaceitáveis, podendo ser qualitativos ou quantitativos. Cada parâmetro estabelecido deve ter o seu limite crítico estabelecido, de forma a manter a visão clara das medidas de controle dos PCCs.

O estabelecimento desses limites deve estar baseado nos conhecimentos disponíveis em fontes como: legislação, literatura científica, dados de pesquisas reconhecidas, normas internas da empresa, etc.

\section{Estabelecer um sistema de monitoramento para cada PCC}

Para assegurar que as medidas de controle operem como planejado nos PCCs e detectem qualquer perda de controle, é necessário definir um sistema de monitoramento dos PCCs. Neste deve estar definido qual o procedimento de controle que deve estar associado a cada PCC. Os métodos de controle devem ser rápidos, para serem efetivos. O sistema de monitoração deve permitir, quando possível, que os ajustes sejam feitos antes que uma medida exceda os limites críticos. Medidas físicas e químicas são às vezes preferíveis a testes microbiológicos, porque podem ser levantadas rapidamente e, muitas vezes, indicam a condição microbiológica do produto.

\section{Estabelecer ações corretivas}

Ações corretivas específicas devem ser definidas para cada PCC identificado no sistema APPCC, a fim de que possa trazer o PCC sob controle, definir o que fazer com o produto que saiu enquanto o PCC estava fora de controle e descobrir porque o PCC estava fora de controle. Os desvios e procedimentos para disposição dos produtos devem estar documentados.

\section{Estabelecer procedimento de verificação}

A aplicação de métodos de verificação e auditoria, procedimentos e testes, incluindo amostragem e análises aleatórias, podem ser utilizados para testar se o sistema 
APPCC está funcionando corretamente. De maneira regular ou não planejada, a informação disponível no sistema APPCC deve ser sistematicamente analisada.

\section{Estabelecer documentação e manter registros}

Os procedimentos do sistema APPCC devem estar documentados, assim como os registros das atividades de monitoramento dos PCCs, das ações corretivas relacionadas aos desvios e das modificações do sistema APPCC. Estas informações devem ser mantidas para acompanhamento e revisões subseqüentes.

\subsubsection{Diretrizes para a aplicação do sistema APPCC}

Antes de aplicar o sistema APPCC a qualquer setor da cadeia alimentar, é necessário que o setor tenha programas como; boas práticas de higiene, conforme aos Princípios Gerais de Higiene dos Alimentos do Codex Alimentarius, e requisitos apropriados em matéria de inocuidade dos alimentos. Estes programas prévios necessários para o sistema de APPCC, incluída a capacitação, devem estar firmemente estabelecidos e em pleno funcionamento, deve se ter verificado adequadamente para facilitar a aplicação eficaz deste sistema.

Em todos os tipos de empresa do setor alimentício é necessário o conhecimento e o compromisso por parte da direção para poder aplicar um sistema de APPCC eficaz. Esta eficácia também vai depender que a direção e os funcionários tenham o conhecimento, motivação, e atitudes técnicas adequados em relação com o sistema de APPCC.

$\mathrm{Na}$ identificação do perigo, na sua avaliação e nas operações seguintes de desenho e aplicação de sistemas de APPCC deverá se ter em conta os efeitos das matérias primas, os ingredientes, as práticas de manufatura de alimentos, a função dos processos de manufatura no controle dos perigos, o uso final provável do produto, as categorias de consumidores afetados e os dados epidemiológicos relativos à inocuidade dos alimentos. 
A finalidade do sistema de APPCC é que o controle se focalize nos pontos críticos de controle (PCC). No caso de que se identifique um perigo, se terá que controlar, de não encontrar nenhum PCC, deverá se considerar a possibilidade de re-desenhar a operação.

O sistema de APPCC deverá se aplicar a cada operação concreta por separado. Pode ocorrer o caso em que os PCC identificados num certo exemplo de algum código de práticas de higiene do Codex Alimentarius não sejam os únicos que se determina para uma aplicação concreta, ou que sejam de natureza diferente.

Quando se introduz alguma modificação no produto, no processo ou em qualquer fase, será necessário examinar a aplicação do sistema de APPCC e realizar as mudanças necessárias.

Cada empresa deve-se encarregar da aplicação dos princípios do sistema de APPCC; Entretanto, os governos e as empresas são conscientes de que pode haver obstáculos que podem impedir a aplicação eficaz deste sistema pela própria empresa. Isto pode ocorrer sobre tudo nas empresas pequenas e/ou menos desenvolvidas. Reconhece-se que o APPCC deve ser aplicado com a flexibilidade apropriada; devem-se observar os sete princípios no qual o sistema se baseia. Essa flexibilidade deve levar em conta a natureza e envergadura da atividade, incluídos os recursos humanos e financeiros; a infra-estrutura, os procedimentos, os conhecimentos e as limitações práticas.

No mundo, existem duas certificações acreditadas do APPCC. Uma pela entidade Holandesa RVA e outra pela entidade Dinamarquesa DANAK. No Brasil o BVQI (Bureau Veritas Quality International) possui ambas acreditações para esta certificação. Se deve ter em consideração que a certificação e a acreditação são atividades diferentes sendo a acreditação o reconhecimento da competência técnica para exercer as atividades de avaliação de conformidade, como por exemplo, reconhecimento para certificação (de sistemas de gestão, de produtos, etc.) 


\subsubsection{ISO - International Organization for Standardization}

A sigla ISO significa International Organization for Standardization, ou seja, Organização Internacional de Normalização. Ela é uma organização não governamental que está presente hoje em cerca de 130 países. Esta organização foi fundada em 1947 em Genebra, e sua função é promover a normalização de produtos e serviços, utilizando determinadas normas, para que a qualidade dos produtos seja sempre melhorada. No Brasil, o órgão que representa a ISO chama-se ABNT (Associação Brasileira de Normas Técnicas) A ISO 9000 é um modelo de padronização. O selo que as empresas recebem se inicia a partir da ISO $9001 \mathrm{em}$ diante. (BELLENZANI, 2004)

Dentro das ISO, as normas são desenvolvidas em comitês técnicos constituídos por organismos de normalização interessados, especialistas, representantes dos consumidores e governos e academia.

Todos os padrões da ISO são periodicamente submetidos à revisão, por seus respectivos comitês. Tais revisões têm o objetivo de garantir o nível de atualização dos padrões, assim como sua adequação à realidade prática das organizações.

\subsubsection{A série ISO 22000:2005 - Sistema de gestão da segurança de alimentos}

A norma ISO 22000:2005 foi desenvolvida por profissionais da indústria de alimentos conjuntamente com especialistas de organizações internacionais, contando com a cooperação do Codex Alimentarius Comission (Fórum internacional de normalização de alimentos) estabelecido pela Organização das Nações Unidas por meio da Food and Agriculture Organization (FAO) e da Organização Mundial de Saúde (OMS), criado com a finalidade de proteger a saúde dos consumidores, Global Food Safety Initiative (GFSI) e Confederation of Food and Drink Industries of the European Union (CIAA).

Esta norma tem por finalidade assegurar que os alimentos estejam seguros para 0 consumo final, através da ótica da cadeia produtiva de alimentos. Esta norma internacional especifica os requisitos para um sistema de segurança de alimentos 
onde uma organização na cadeia produtiva de alimentos precisa demonstrar sua habilidade em controlar os perigos à segurança de alimentos, a fim de garantir que o alimento está seguro até o momento do consumo humano.

É mais abrangente que a NBR 14900:2002. Abrange de maneira interessante os requisitos de redes atacadistas e de varejo mundiais $O$ seu grande desafio é ser aceita por todos os segmentos da Cadeia Alimentar.

Todos os requisitos desta norma são genéricos e aplicáveis a todas as organizações na cadeia produtiva de alimentos, independentemente de tamanho e complexidade. Isto inclui as que estão direta ou indiretamente envolvidas em uma ou mais etapas da cadeia produtiva de alimentos. Organizações que estão diretamente envolvidas incluem, mas restritamente, produtores de alimentos para consumo animal, agricultores, fazendeiros, produtores de ingredientes, fabricantes, distribuidores, serviços de alimentação e abastecimento, empresas fornecedoras de serviços de limpeza, serviços de transporte, estoque e distribuição. Outras organizações que estão envolvidas indiretamente incluem: fornecedores de equipamentos, produtos de limpeza, embalagens e outros materiais que entram em contato com os alimentos.

A norma é constituída por três partes:

- Requisitos de Boas Práticas ou programas de pré-requisitos do sistema APPCC;

- Requisitos do Sistema APPCC de acordo com os princípios estabelecidos pela Comissão do Codex Alimentarius;

- Requisitos de um sistema de gestão baseados nos princípios de melhoria contínua. 


\section{METODOLOGIA}

A análise conduzida neste trabalho compreende uma avaliação de compatibilidade e adequação dessa ferramenta no programa com as exigências técnicas e sanitárias da água para reúso na indústria de alimentos. A pesquisa foi desenvolvida considerando-se as seguintes etapas:

a) Revisão bibliográfica sobre os principais aspectos relacionados à ferramenta de APPCC e reúso de água.

b) Visitas técnicas realizadas à empresa Givaudan, com o objetivo de avaliar mais detalhadamente, os setores de produção de aromas e fragrâncias, os laboratórios de análise dos produtos finais, sistemas de lavagem de gases e sistema de ar condicionado, considerados os maiores consumidores de água, e procurou-se as possíveis aplicações do reúso de água apoiada pela ferramenta do APPCC.

c) A análise e descrição dos processos produtivos de aromas e fragrâncias da empresa, desde a entrada da matéria prima até o produto final, para determinar as áreas e processos com maior demanda de água.

d) Acompanhamento de algumas operações onde ocorre o consumo de água e a geração de efluentes, buscando-se avaliar a variação da concentração de alguns parâmetros de qualidade do efluente gerado.

e) Avaliação do atual processo de tratamento do efluente gerado no processo produtivo, visando identificar a necessidade de alterações para viabilizar a prática de reúso de água;

f) Análise do potencial de reúso da água do processo de acordo com os parâmetros evidenciados e apoiados pela ferramenta APPCC;

g) Identificação dos pontos recomendados para estudos futuros. 


\section{RESULTADOS E DISCUSSÕES}

\subsection{Características da empresa}

A empresa na qual foi desenvolvido este projeto de pesquisa é a Givaudan, localizada na Cidade de São Paulo, Brasil É uma empresa de origem Suíça, de natureza jurídica privada, pertencente à categoria de empresas do ramo da indústria química atuante no segmento de Fabricação de Essências para Aromas e Fragrâncias.

A Givaudan esta presente em 40 paises e possui, em seu quadro, por volta de 6,000 funcionários em todo o mundo, trabalhando em turnos contínuos.

Como resultado de sua longa e rica trajetória, Givaudan traz o conhecimento institucional das empresas predecessoras que datam desde o final do século XVIII, até o início da moderna indústria de aromas e fragrâncias.

A Givaudan possui, desde o 2003, as certificações ISO 9001:2000 e a SA 8000, esta certificada pelo grupo SGS (Société Générale de Surveillance) a maior organização mundial no domínio da inspeção, verificação e certificação.

Basicamente a Givaudan está organizada em duas divisões:

\section{a) Aromas}

A Givaudan entende que a receptividade de um aroma ou sabor pelo mercado de bebidas e alimentos depende de uma ampla combinação de hábitos de consumo e preferências locais. A criação de um aroma é uma ciência intimamente relacionada com a psicologia humana, percepções sensoriais e aspectos culturais. Com mais de 200 anos de experiência a Givaudan é considerada líder mundial no segmento de aromas, contando com tecnologia de ponta para o desenvolvimento de novas moléculas, ingredientes e sabores. 
A área de Aromas na Givaudan é dividido e organizado por segmentos:

- Bebidas: carbonatados, refrescos em pó,sucos, bebidas instantâneas, chás, cafés,águas, isotônicos e alcoólicos.

- Lácteos: iogurtes, sorvetes, modificadores de leite, produtos a base de soja e margarinas.

- Forneados: bolos, biscoitos.

- Doces e confeitos: sobremesas, balas, chicles e chocolates.

- Hlgiene Bucal: cremes dentais e enxaguatórios bucais.

- Salgados e Culinários: salgadinhos, caldos, sopas, molhos, condimentos, queijos, e comida para animais de estimação, e comida rápida.

- Tabaco

b) Fragrâncias

A Divisão de Fragrâncias está organizada globalmente em 3 unidades de negócios :

\section{- Perfumaria Fina}

Desenvolvimento de fragrâncias para as principais marcas de perfumes do mercado local, regional e internacional. Perfumes, extratos, colônias, deo colônias, extensões de linha tanto para homens, mulheres, e crianças.

\section{- Produtos de Consumo}

Desenvolvimento de fragrâncias para produtos de cuidado com a roupa, cuidado pessoal e cuidado com a casa, tais como detergente em pó, amaciantes, sabonetes, shampoo, desinfetantes, perfumadores de ambiente.

\section{- Ingredientes}

Desenvolvimento de moleculas especifica para utilização na perfumaria tanto internamente como para venda a terceiros e outras casas de fragrâncias. 


\subsubsection{Sistema de abastecimento de água na planta}

A Givaudan, para atingir a demanda de água, utiliza duas fontes distintas para seu abastecimento (doméstico e industrial); em 2006 a Sabesp forneceu $24.621 \mathrm{~m}^{3}$, enquanto que o sistema da Hidrogesp (prestadora de serviço) contribuiu com 27.251 $\mathrm{m}^{3}$ da captação de água subterrânea para suprir a demanda industrial. As tabelas 6 e 7, apresentam dados de consumos e custos com água e esgoto referentes ao fornecimento da Sabesp e Hidrogesp em 2006.

Tabela 6 - Consumos e custos referentes ao fornecimento da Sabesp em 2006

\begin{tabular}{|c|c|c|c|c|c|c|c|}
\hline MÊS & $\begin{array}{l}\text { CONSUMO } \\
\text { ÁGUA }\left(\mathrm{m}^{3}\right)\end{array}$ & $\begin{array}{c}\text { CUSTO } \\
\text { ÁGUA } \\
\text { (R\$) }\end{array}$ & $\begin{array}{c}\text { EFLUENTES } \\
\left(\mathbf{m}^{3}\right)\end{array}$ & $\begin{array}{c}\text { CUSTO } \\
\text { EFLUENTES } \\
\text { (R\$) }\end{array}$ & $\begin{array}{c}\text { CUSTO } \\
\text { TOTAL } \\
\text { (R\$) }\end{array}$ & $\begin{array}{l}R \$ / \mathrm{m}^{3} \\
\text { (ÁGUA) }\end{array}$ & $\begin{array}{l}\mathrm{R} \$ / \mathrm{m}^{3} \\
\text { (EFLU.) }\end{array}$ \\
\hline Jan & 976 & 8420,30 & 976 & 11368,67 & 19788,97 & 8,63 & 11,65 \\
\hline Fev & 1988 & 17275,84 & 1988 & 23322,38 & 40598,22 & 8,69 & 11,73 \\
\hline Mar & 1976 & 17170,84 & 1976 & 23180,63 & 40351,47 & 8,69 & 11,73 \\
\hline Abr & 1955 & 16987,09 & 1955 & 22932,57 & 39919,66 & 8,69 & 11,73 \\
\hline Mai & 2661 & 23164,59 & 2661 & 31272,20 & 54436,79 & 8,71 & 11,75 \\
\hline Jun & 2054 & 17844,59 & 2054 & 24090,20 & 41934,79 & 8,69 & 11,73 \\
\hline Jul & 1817 & 15770,84 & 1817 & 21290,63 & 37061,47 & 8,68 & 11,72 \\
\hline Ago & 1770 & 15368,34 & 1770 & 20747,26 & 36115,61 & 8,68 & 11,72 \\
\hline Set & 2159 & 19523,59 & 2159 & 26365,85 & 45889,44 & 9,04 & 12,21 \\
\hline Out & 2050 & 19028,89 & 2050 & 25689,00 & 44717,89 & 9,28 & 12,53 \\
\hline Nov & 2413 & 22409,97 & 2413 & 30253,46 & 52663,43 & 9,29 & 12,54 \\
\hline Dez & 2282 & 20735,44 & 2282 & 28659,63 & 49395,07 & 9,09 & 12,56 \\
\hline TOTAL & 24101 & 213700,3 & 24101 & 289172,5 & 502872,8 & 8,85 & 11,97 \\
\hline
\end{tabular}

Fonte: Givaudan (2006)

Tabela 7 - Consumos e custos referentes ao fornecimento da Hidrogesp em 2006

\begin{tabular}{|c|c|c|c|c|c|c|c|}
\hline MÊS & $\begin{array}{l}\text { CONSUMO } \\
\text { ÁGUA DE } \\
\text { POÇO }\left(\mathrm{m}^{3}\right)\end{array}$ & $\begin{array}{c}\text { CUSTO } \\
\text { ÁGUA DE } \\
\text { POÇO (R\$) }\end{array}$ & $\begin{array}{c}\text { EFLUENTES } \\
\left(\mathrm{m}^{3}\right)\end{array}$ & $\begin{array}{c}\text { CUSTO } \\
\text { EFLUENTES } \\
\text { (R\$) }\end{array}$ & $\begin{array}{l}\text { CUSTO } \\
\text { TOTAL } \\
\text { (R\$) }\end{array}$ & $\begin{array}{l}\mathrm{R} \$ / \mathrm{m}^{3} \\
\text { (ÁGUA } \\
\text { POÇO) }\end{array}$ & $\begin{array}{l}\mathrm{R} \$ / \mathrm{m}^{3} \\
\text { (EFLU.) }\end{array}$ \\
\hline Jan & 2142 & 8373,42 & 876 & 10347,75 & 18721,17 & 3,91 & 11,81 \\
\hline Fev & 1037 & 4665,03 & 730 & 8623,13 & 13288,16 & 4,50 & 11,81 \\
\hline Mar & 1931 & 8688,69 & 589 & 6957,56 & 15646,25 & 4,50 & 11,81 \\
\hline Abr & 2832 & 12745,80 & 1159 & 13690,69 & 26436,49 & 4,50 & 11,81 \\
\hline Mai & 2178 & 9801,32 & 966 & 11410,88 & 21212,2 & 4,50 & 11,81 \\
\hline Jun & 1988 & 8946,35 & 976 & 11529,00 & 20475,35 & 4,50 & 11,81 \\
\hline Jul & 903 & 4063,39 & 979 & 11564,44 & 15627,83 & 4,50 & 11,81 \\
\hline Ago & 2649 & 11921,85 & 1102 & 13017,38 & 24939,23 & 4,50 & 11,81 \\
\hline Set & 2618 & 11779,88 & 1109 & 13624,67 & 25404,55 & 4,50 & 12,29 \\
\hline Out & 2533 & 11625,00 & 1019 & 12848,57 & 24473,57 & 4,59 & 12,61 \\
\hline Nov & 1876 & 8724,70 & 825 & 10402,43 & 19127,13 & 4,65 & 12,61 \\
\hline Dez & 1873 & 8970,05 & 1067 & 13456,88 & 22426,93 & 4,79 & 12,61 \\
\hline TOTAL & 24559 & 110305,48 & 11518 & 137473,38 & 247778,86 & 4,50 & 12,05 \\
\hline
\end{tabular}

Fonte: Givaudan (2006) 


\subsubsection{Análises laboratoriais da água na planta}

As análises físico-químicos e bacteriológicos da água foram feitas no mês de outubro de 2006 pela Hidrolabor Laboratório de Controle Ltda, sendo localizadas as amostras na saída do poço tubular e na saída da ETA.

Os resultados das análises físico-quimicas e bacteriológicas da amostra de água na saída do poço tubular não se encontravam dentro dos padrões de potabilidade estabelecidos conforme a Portaria 518 de 25 de março de 2004 do Ministério da Saúde, sendo uma característica natural em águas subterrâneas depois essa água é tratada através de processos físico-químicos. Nas tabelas 8, 9, e 10, são apresentados os resultados destas análises.

Tabela 8 - Analise de água para consumo humano na saída do poço tubular profundo em outubro de 2006.

\begin{tabular}{|c|c|c|c|c|}
\hline Parâmetro & Unidades & V.M.P & L.Q & Resultado \\
\hline \multicolumn{5}{|c|}{ AGUA PARA CONSUMO HUMANO } \\
\hline Alumínio & $\mathrm{mg} \mathrm{Al} / \mathrm{L}$ & 0,2 & 0,1 & $<\mathrm{LQ}$ \\
\hline Amônia & $\mathrm{mg} \mathrm{NH}_{3} / \mathrm{L}$ & 1,5 & 0,1 & 0,31 \\
\hline Cloretos & $\mathrm{mg} \mathrm{Cl} / \mathrm{L}$ & 250 & 1 & 26,3 \\
\hline Cor aparente & $\mathrm{UH}$ & 15 & 5 & 40 \\
\hline Dureza total & $\mathrm{mg} \mathrm{CaCO}_{3} / \mathrm{L}$ & 500 & 1 & 104 \\
\hline Etilbenzeno & $\mathrm{mg} / \mathrm{L}$ & 0,2 & 0,002 & $<\mathrm{LQ}$ \\
\hline Ferro & $\mathrm{mg} \mathrm{Fe} / \mathrm{L}$ & 0,3 & 0,05 & 2,32 \\
\hline Manganês & $\mathrm{mg} \mathrm{Mn} \mathrm{/} \mathrm{L}$ & 0,1 & 0,05 & 0,38 \\
\hline Monoclorobenceno & $\mathrm{mg} / \mathrm{L}$ & 0,12 & 0,002 & $<\mathrm{LQ}$ \\
\hline Odor & --- & Não Objetável & --- & $\mathrm{N} . \mathrm{O}$ \\
\hline Gosto & --- & Não Objetável & --- & $\mathrm{N} . \mathrm{O}$ \\
\hline Sódio & $\mathrm{mg} \mathrm{Na} / \mathrm{L}$ & 200 & 0,01 & 25,58 \\
\hline Sólidos totais dissolvidos & $\mathrm{mg} / \mathrm{L}$ & 1000 & 1 & 234 \\
\hline Sulfato & $\mathrm{mg} \mathrm{SO}_{4} / \mathrm{L}$ & 250 & 1 & 14,99 \\
\hline Sulfato de Hidrogênio & $\mathrm{mg} \mathrm{S} \mathrm{/} \mathrm{L}$ & 0,05 & 0,02 & $<\mathrm{LQ}$ \\
\hline Surfactantes & $\mathrm{mg}$ LAS / L & 0,5 & 0,1 & $<\mathrm{LQ}$ \\
\hline Tolueno & $\mathrm{mg} / \mathrm{L}$ & 0,17 & 0,002 & $<L Q$ \\
\hline Turbidez & em NTU & 5 & 0,01 & 18,4 \\
\hline $\mathrm{pH}$ & --- & $6,0-9,5$ & 0,01 & 6,51 \\
\hline Zinco & $\mathrm{mg} Z \mathrm{n} / \mathrm{L}$ & 5 & 0,01 & 0,18 \\
\hline Xileno & $\mathrm{mg} / \mathrm{L}$ & 0,3 & 0,002 & $<L Q$ \\
\hline
\end{tabular}

V.M.P = valores máximos permitidos

L.Q = Limite de quantificação

$<=$ menor

Data de Entrega: 03/10/2006

Origem: Poço Tubular Profundo

Fonte: HODROLABOR 
Tabela 9 - Analise dos inorgânicos e orgânicos da água na saída do poço tubular profundo em outubro de 2006.

\begin{tabular}{|c|c|c|c|c|}
\hline Parâmetro & Unidades & V.M.P & L.Q & Resultado \\
\hline \multicolumn{5}{|c|}{ INORGÂNICOS } \\
\hline Antimônio & $\mathrm{mg} \mathrm{Sbl} \mathrm{/} \mathrm{L}$ & 0,005 & 0,001 & $<\mathrm{LQ}$ \\
\hline Arsênio & $\mathrm{mg} \mathrm{As} / \mathrm{L}$ & 0,01 & 0,01 & $<\mathrm{LQ}$ \\
\hline Bário & $\mathrm{mg} \mathrm{Ba} / \mathrm{L}$ & 0,7 & 0,5 & $<\mathrm{LQ}$ \\
\hline Cádmio & $\mathrm{mg} \mathrm{Cd} / \mathrm{L}$ & 0,005 & 0,003 & $<\mathrm{LQ}$ \\
\hline Chumbo & $\mathrm{mg} \mathrm{Pb} / \mathrm{L}$ & 0,01 & 0,005 & $<\mathrm{LQ}$ \\
\hline Cobre & $\mathrm{mg} \mathrm{Cu} / \mathrm{L}$ & 2,0 & 0,1 & $<\mathrm{LQ}$ \\
\hline Cianeto & $\mathrm{mg} \mathrm{CN} / \mathrm{L}$ & 0,07 & 0,05 & $<\mathrm{LQ}$ \\
\hline Cromo Total & $\mathrm{mg} \mathrm{Cr} / \mathrm{L}$ & 0,06 & 0,01 & $<\mathrm{LQ}$ \\
\hline Fluoretos & $\mathrm{mg} \mathrm{F} / \mathrm{L}$ & 1,5 & 0,1 & 0,37 \\
\hline Mercúrio & $\mathrm{mg} \mathrm{Hg} / \mathrm{L}$ & 0,001 & 0,0005 & $<\mathrm{LQ}$ \\
\hline Nitrato & $\mathrm{mg} \mathrm{N} / \mathrm{L}$ & 10 & 0,05 & $<\mathrm{LQ}$ \\
\hline Nitrito & $\mathrm{mg} \mathrm{N} / \mathrm{L}$ & 1,0 & 0,05 & $<\mathrm{LQ}$ \\
\hline Selênio & $\mathrm{mg} \mathrm{Se} / \mathrm{L}$ & 0,01 & 0,001 & $<\mathrm{LQ}$ \\
\hline \multicolumn{5}{|c|}{ ORGÂNICOS } \\
\hline Acrilamida & $\mu \mathrm{g} / \mathrm{L}$ & 0,5 & 0,1 & $<\mathrm{LQ}$ \\
\hline Benzeno & $\mu \mathrm{g} / \mathrm{L}$ & 5,0 & 2,0 & $<\mathrm{LQ}$ \\
\hline Benzopireno & $\mu \mathrm{g} / \mathrm{L}$ & 0,7 & 0,3 & $<\mathrm{LQ}$ \\
\hline Cloreto de Vinila & $\mu \mathrm{g} / \mathrm{L}$ & 5,0 & 2,0 & $<\mathrm{LQ}$ \\
\hline 1,2 Dicloroetano & $\mu \mathrm{g} / \mathrm{L}$ & 10 & 2,0 & $<\mathrm{LQ}$ \\
\hline 1,1 Dicloroeteno & $\mu \mathrm{g} / \mathrm{L}$ & 30 & 2,0 & $<\mathrm{LQ}$ \\
\hline Diclorometano & $\mu \mathrm{g} / \mathrm{L}$ & 20 & 2,0 & $<\mathrm{LQ}$ \\
\hline Estireno & $\mu \mathrm{g} / \mathrm{L}$ & 20 & 2,0 & $<\mathrm{LQ}$ \\
\hline Tetracloro de Carbono & $\mu \mathrm{g} / \mathrm{L}$ & 2,0 & 2,0 & $<\mathrm{LQ}$ \\
\hline Tetracloroeteno & $\mu \mathrm{g} / \mathrm{L}$ & 40 & 2,0 & $<\mathrm{LQ}$ \\
\hline Triclorobenzenos & $\mu \mathrm{g} / \mathrm{L}$ & 20 & 2,0 & $<\mathrm{LQ}$ \\
\hline Tricloroeteno & $\mu \mathrm{g} / \mathrm{L}$ & 70 & 2,0 & $<\mathrm{LQ}$ \\
\hline
\end{tabular}

V.M.P = valores máximos permitidos

L.Q $=$ Limite de quantificação

$<=$ menor

Data de Entrega: 03/10/2006

Origem: Poço Tubular Profundo

Fonte: HODROLABOR 
Tabela 10 - Analise de agrotóxicos, desinfetantes e microbiológicos da água na saída do poço tubular profundo em outubro de 2006.

\begin{tabular}{|c|c|c|c|c|}
\hline Parâmetro & Unidades & V.M.P & L.Q & Resultado \\
\hline \multicolumn{5}{|c|}{ AGROTÓXICOS } \\
\hline Alaclor & $\mu \mathrm{g} / \mathrm{L}$ & 20 & 1,0 & $<\mathrm{LQ}$ \\
\hline Aldrin e Dieldrin & $\mu \mathrm{g} / \mathrm{L}$ & 0,03 & 0,03 & $<\mathrm{LQ}$ \\
\hline Atrazina & $\mu \mathrm{g} / \mathrm{L}$ & 2,0 & 0,5 & $<\mathrm{LQ}$ \\
\hline Bentazona & $\mu \mathrm{g} / \mathrm{L}$ & 300 & 5,0 & $<\mathrm{LQ}$ \\
\hline Clordano (isomeros) & $\mu \mathrm{g} / \mathrm{L}$ & 0,2 & 0,1 & $<\mathrm{LQ}$ \\
\hline $2,4 \mathrm{D}$ & $\mu \mathrm{g} / \mathrm{L}$ & 30 & 0,5 & $<\mathrm{LQ}$ \\
\hline DDT (Isómeros) & $\mu \mathrm{g} / \mathrm{L}$ & 2,0 & 0,1 & $<\mathrm{LQ}$ \\
\hline Endossulfan & $\mu \mathrm{g} / \mathrm{L}$ & 20 & 200 & $<\mathrm{LQ}$ \\
\hline Endrin & $\mu \mathrm{g} / \mathrm{L}$ & 0,6 & 0,03 & 0,37 \\
\hline Gilfosato & $\mu \mathrm{g} / \mathrm{L}$ & 500 & 0,05 & $<\mathrm{LQ}$ \\
\hline Hepacloro e hepacloro hepóxido & $\mu \mathrm{g} / \mathrm{L}$ & 0,03 & 0,05 & $<\mathrm{LQ}$ \\
\hline Hexaclorobenceno & $\mu \mathrm{g} / \mathrm{L}$ & 1,0 & 1,0 & $<\mathrm{LQ}$ \\
\hline Lindano & $\mu \mathrm{g} / \mathrm{L}$ & 2,0 & 0,2 & $<\mathrm{LQ}$ \\
\hline Metotacloro & $\mu \mathrm{g} / \mathrm{L}$ & 10 & 1,0 & \\
\hline Meloxicloro & $\mu \mathrm{g} / \mathrm{L}$ & 20 & 0,2 & $<\mathrm{LQ}$ \\
\hline Molinato & $\mu \mathrm{g} / \mathrm{L}$ & 6,0 & 0,5 & $<\mathrm{LQ}$ \\
\hline Pendimetalina & $\mu \mathrm{g} / \mathrm{L}$ & 20 & 1,0 & $<\mathrm{LQ}$ \\
\hline Pentaclorofenol & $\mu \mathrm{g} / \mathrm{L}$ & 9,0 & 5,0 & $<\mathrm{LQ}$ \\
\hline Permetrina & $\mu \mathrm{g} / \mathrm{L}$ & 20 & 1,0 & $<\mathrm{LQ}$ \\
\hline Properil & $\mu \mathrm{g} / \mathrm{L}$ & 20 & 5,0 & $<\mathrm{LQ}$ \\
\hline Simazina & $\mu \mathrm{g} / \mathrm{L}$ & 2,0 & 1,0 & $<\mathrm{LQ}$ \\
\hline Trifuralina & $\mu \mathrm{g} / \mathrm{L}$ & 20 & 1,0 & $<\mathrm{LQ}$ \\
\hline \multicolumn{5}{|c|}{ DESINFETANTES E PRODUTOS SECUNDARIOS DE DESINFECÇÃO } \\
\hline $2,4,6$ Triclorofenol & $\mathrm{mg} / \mathrm{L}$ & 0,2 & 0,002 & $<L Q$ \\
\hline Trihalometanos Total & $\mathrm{mg} / \mathrm{L}$ & 0,1 & 0,008 & 0,011 \\
\hline Bromato & $\mathrm{mg} / \mathrm{L}$ & 0,025 & 0,005 & $<\mathrm{LQ}$ \\
\hline Clorito & $\mathrm{mg} / \mathrm{L}$ & 0,2 & 0,1 & $<\mathrm{LQ}$ \\
\hline Cloro Livre & $\mathrm{mg} / \mathrm{L}$ & 5,0 & 0,1 & $<\mathrm{LQ}$ \\
\hline Monocloroamina & $\mathrm{mg} / \mathrm{L}$ & 3,0 & 0,1 & $<\mathrm{LQ}$ \\
\hline \multicolumn{5}{|c|}{ RESULTADOS MICROBIOLÓGICOS } \\
\hline $\begin{array}{l}\text { Escherichia coli ou } \\
\text { coliformes termotolerantes }\end{array}$ & P/A em $100 \mathrm{~mL}$ & ausente & --- & ausência \\
\hline Coliformes Totais & P/A em $100 \mathrm{~mL}$ & ausente & --- & ausência \\
\hline
\end{tabular}

V.M.P = valores máximos permitidos

L. $Q=$ Limite de quantificação

$<=$ menor

Data de Entrega: 03/10/2006

Origem: Poço Tubular Profundo

Fonte: HODROLABOR

Após a sua captação, a água é submetida a um processo de tratamento a través de processos físico-químicos, sendo posteriormente distribuída para os diversos pontos de consumo e para os sistemas de produção de água com características especificas, em função do uso a que a água se destina. 
A água potável ou de consumo doméstico, é utilizada basicamente para ser consumida nos bebedouros, higiene pessoal, e descarga em sanitários. Após a sua utilização, a maior parte da água é convertida em esgoto sanitário. Os resultados das análises físico-químicas e bacteriológicas da amostra de água da saída da ETA encontraram-se dentro dos padrões de potabilidade, é apresentado na tabela 11.

Tabela 11 - Analises físico-químicas e bacteriológicas da amostra de água da saída da ETA em outubro de 2006.

\begin{tabular}{|c|c|c|c|c|}
\hline Parâmetros & Unidades & V.M.P & L.Q & Resultado \\
\hline Aspecto & -- & límpido & & límpido \\
\hline Odor & --- & não objetável & & nenhum \\
\hline $\mathrm{pH}$ & --- & entre 6 e 9,5 & 0,01 & 6,69 \\
\hline Turbidez & NTU & Até 5,0 & 0,01 & 0,35 \\
\hline Sólidos Totais Dissolvidos & $\mathrm{mg} / \mathrm{L}$ & Até 1000 & 0,10 & 249,6 \\
\hline Cor & $\mathrm{UH}$ & Até 15,0 & 5,0 & 5,0 \\
\hline Alcalinidade de Hidróxidos & $\mathrm{mg} \mathrm{CACO}{ }_{3} / \mathrm{L}$ & --- & --- & 0,0 \\
\hline Alcalinidade de Carbonatos & $\mathrm{mg} \mathrm{CACO}_{3} / \mathrm{L}$ & --- & 1,0 & $<\mathrm{LQ}$ \\
\hline Alcalinidade de Bicarbonatos & $\mathrm{mg} \mathrm{CACO}_{3} / \mathrm{L}$ & -- & 1,0 & 122 \\
\hline Dureza de Carbonatos & $\mathrm{mg} \mathrm{CACO} 3 / \mathrm{L}$ & --- & 1,0 & 102 \\
\hline Dureza de Não Carbonatos & $\mathrm{mg} \mathrm{CACO}_{3} / \mathrm{L}$ & --- & 1,0 & $<\mathrm{LQ}$ \\
\hline Dureza Total & $\mathrm{mg} \mathrm{CACO}{ }_{3} / \mathrm{L}$ & Até 500 & 1,0 & 102 \\
\hline Cloretos & $\mathrm{mg} \mathrm{Cl} / \mathrm{L}$ & Até 250 & 1,0 & 43,8 \\
\hline Nitrogênio Amoniacal & $\mathrm{mg} \mathrm{N} / \mathrm{L}$ & Até 1,5 & 0,10 & $<\mathrm{LQ}$ \\
\hline Ferro & $\mathrm{mg} \mathrm{Fe} / \mathrm{L}$ & Até 0,30 & 0,05 & $<\mathrm{LQ}$ \\
\hline Nitrato & $\mathrm{mg} \mathrm{N} / \mathrm{L}$ & Até 10,0 & 0,05 & $<L Q$ \\
\hline Nitrito & $\mathrm{mg} \mathrm{N} / \mathrm{L}$ & Até 1,0 & 0,05 & $<\mathrm{LQ}$ \\
\hline Sulfato & $\mathrm{mg} \mathrm{SO} 4 / \mathrm{L}$ & Até 250 & 1,0 & 15 \\
\hline Condutividade & $\mu \mathrm{S} / \mathrm{cm}$ a $25^{\circ} \mathrm{C}$ & -- & 1,0 & 384 \\
\hline Sílica & $\mathrm{mg} \mathrm{SiO} 2 / \mathrm{L}$ & --- & 0,5 & 28,07 \\
\hline Cloro Residual Livre & $\mathrm{mg} \mathrm{Cl} / \mathrm{L}$ & Até 2,0 & 0,01 & 1,5 \\
\hline Gás Carbônico & $\mathrm{mg} \mathrm{CO} 2 / \mathrm{L}$ & -- & --- & 49,7 \\
\hline Manganês & $\mathrm{mg} \mathrm{Mn} \mathrm{/} \mathrm{L}$ & Até 0,1 & 0,05 & $<L Q$ \\
\hline Cobre & $\mathrm{mg} \mathrm{Cu} / \mathrm{L}$ & Até 2,0 & 0,1 & $<\mathrm{LQ}$ \\
\hline Zinco & $\mathrm{mg} \mathrm{Zn} \mathrm{/} \mathrm{L}$ & Até 5,0 & 0,01 & 0,05 \\
\hline Flúor & $\mathrm{mg} F / \mathrm{L}$ & --- & 0,1 & 0,58 \\
\hline I Langelier & --- & --- & --- & $-0,93$ \\
\hline \multicolumn{5}{|c|}{ RESULTADOS MICROBIOLÓGICOS } \\
\hline \multirow{3}{*}{$\begin{array}{l}\text { Coliformes Totais } \\
\text { Coliformes Termotolerantes } \\
\text { Bactérias Heterotróficas ( } 48 \mathrm{hs} \text { ) }\end{array}$} & UFC / $100 \mathrm{~mL}$ & ausência & --- & ausência \\
\hline & UFC / $100 \mathrm{~mL}$ & ausência & --- & ausência \\
\hline & UFC / mL & $500^{*}$ & 10 & --- \\
\hline \multicolumn{5}{|l|}{$\begin{array}{l}\text { V.M.P = valores máximos permiti } \\
\text { L.Q = Limite de quantificação } \\
<=\text { menor } \\
\text { Data de Entrega: 03/10/2006 } \\
\text { Origem: Poço Tubular Profundo } \\
\text { Fonte: HODROLABOR }\end{array}$} \\
\hline
\end{tabular}




\subsection{Descrição dos processos de fabricação}

Os maiores consumos de água na empresa estão na área da produção de aromas e fragrâncias. Refere-se às operações de lavagem de equipamentos e utensílios nas áreas de secagem de emulsões e tanques móveis. Além disso o consumo de água é feito na torre de lavagem de gases, descargas de vasos sanitários e irrigação de áreas verdes.

\subsubsection{Sistema de secagem de emulsões}

A unidade de secagem de produto é feito através de um dispositivo denominado Spray Dryer, ou equipamento de secagem por aspersão e aquecimento.

O Spray Dryer é ideal para a secagem de produtos sensíveis ao calor, onde a escolha do sistema e da operação é a chave para se obter o máximo de nutritivos e de qualidade no pó.

No processo de Spray Dryer são preparados aromas e aditivos em pó, pela passagem em um atomizador secador de uma suspensão previamente homogeneizada contendo os princípios aromáticos, água e suporte. A suspensão é forçada na forma de gotículas em uma câmara de secagem contra uma corrente de ar quente; a água evapora instantaneamente e um pó fino (partícula de 10 a 200 micrometros) é coletado em um ciclone anexo. Os princípios aromáticos ficam suspensos em um suporte, protegidos de oxidação e evaporação, diz-se que estão encapsulados. A grande maioria dos aromas em pó comercializados atualmente é produzida por este processo. Na figura 6 se representa o processo de secagem de emulsões Spray Dryer.

As emulsões são preparadas nos tanques de mistura de matérias primas, tendo um grupo de seis tanques, os quais são lavados manualmente com auxílio de mangueiras convencionais, não existindo dispositivos que minimizem o consumo de água. Esta lavagem é feita por uma abertura localizada na parte superior dos mesmos, conforme ilustra a figura 7 


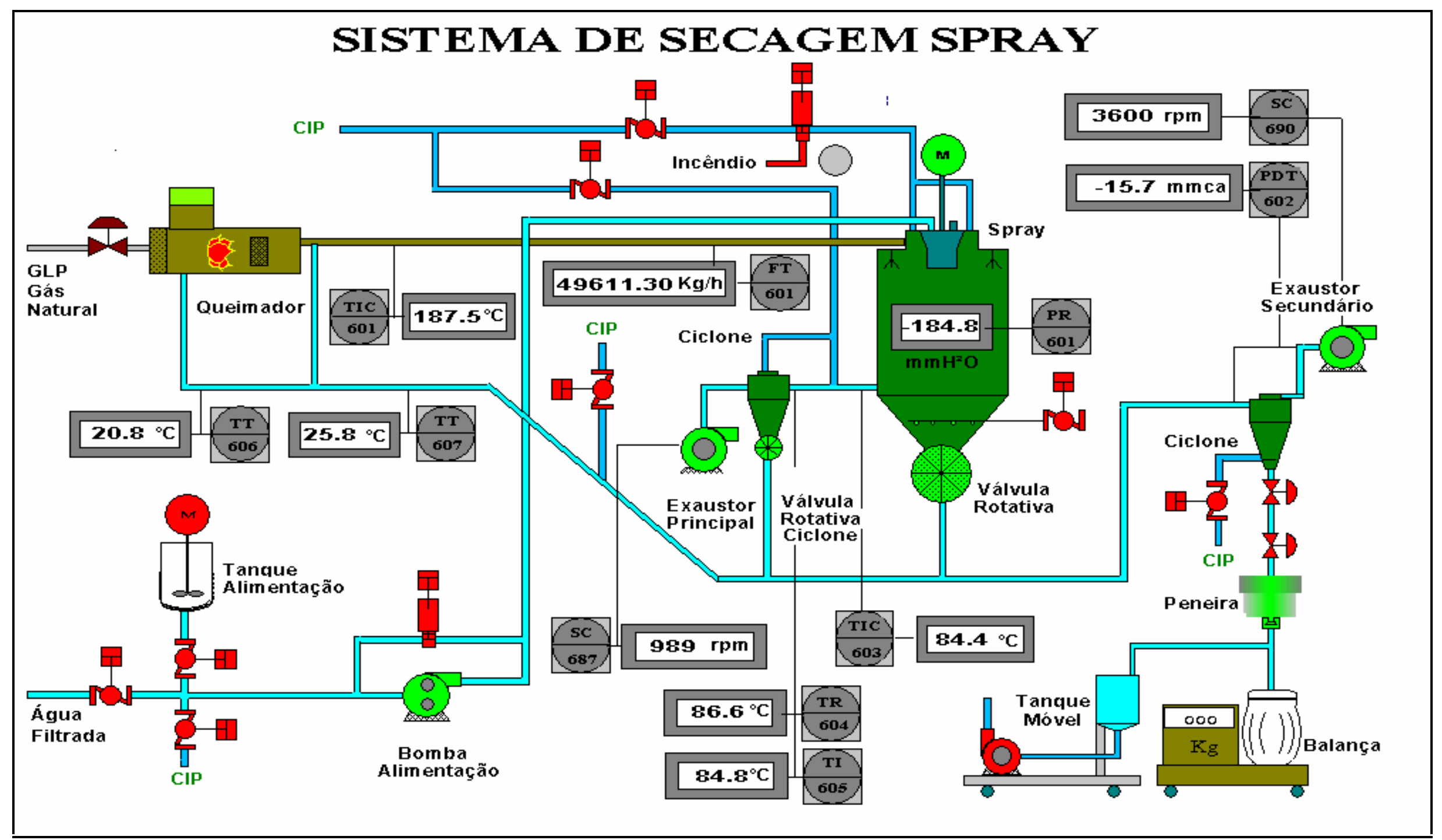

Figura 6 - Sistema de secagem Spray Dryer 


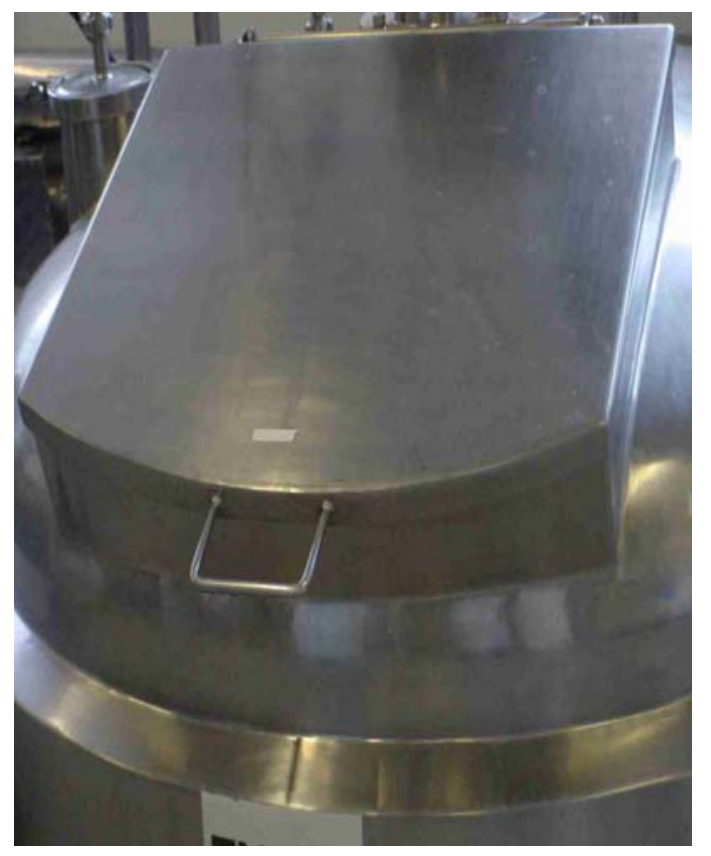

Figura 7 - Abertura utilizada para a operação de lavagem do tanque de preparação de emulsões

Após a preparação nos tanques de mistura, a emulsão é transferida para o tanque de alimentação do sistema de secagem por aspersão e aquecimento, para secar a emulsão e se obter um material na forma de pó que é embalado e armazenado para posterior distribuição. Existem dois sistemas de secagem de emulsão, com a mesma configuração e capacidade de produção.

Quando o tanque de alimentação do sistema de secagem é esgotado é iniciada a operação de limpeza e sanitização de maneira automatizada, por um sistema de CIP (Clean in Place), dotado de tanques de soluções de detergente, sanitizante e água filtrada, além de contar com dispositivos de distribuição de água (spray balls), localizado no interior do secador. A lavagem do tanque de alimentação de emulsão é feita de forma manual, como ocorre com os tanques de preparação. A figura 8 ilustra o sistema central do CIP, com a indicação dos pontos de alimentação das soluções de detergente, sanitizante e água filtrada. 


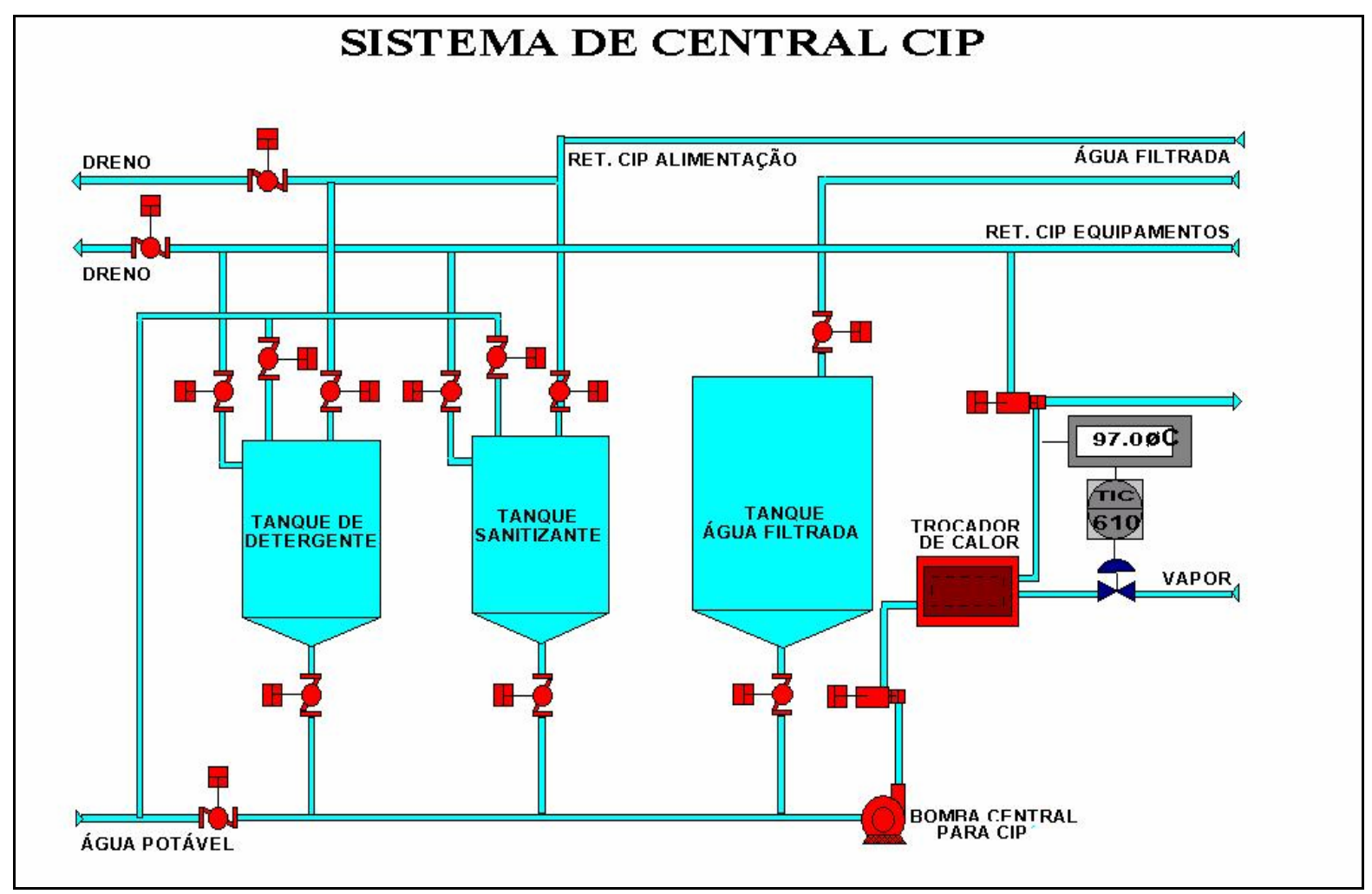

Figura 8 - Introdução das soluções de detergente, sanitizante e água filtrada no sistema de central CIP.

A operação de lavagem do sistema CIP é automática, realizando-se em todos os componentes do sistema de secagem, se inicia pelos equipamentos instalados nos níveis superiores com a água de enxágüe, depois é adicionada soluções de detergente e sanitizante escoando para os níveis inferiores.

Há um primeiro enxágüe com água potável da rede durante aproximadamente 11 minutos para remoção do residual do produto obtido durante o processo produtivo. Logo após inicia-se a limpeza com uma solução de detergente (Divostar Quattro), a qual recircula por 15 minutos, com posterior enxágüe do sistema com água potável da rede que também é descartada. Como segundo passo é a circulação de uma solução sanitizante (Divosan Divosept 350), seguida finalmente pelo enxágüe com água filtrada, sendo que parte retorna ao reservatório de água filtrada para ser reutilizada no próximo ciclo e parte é descartada, principalmente por problemas hidráulicos no sistema. Os tempos, de cada fase da lavagem podem ser observados na tabela 12 . 
Tabela 12 - Tempos de cada etapa de lavagem do tanque Spray Dryer.

\begin{tabular}{lc}
\hline \multicolumn{1}{c}{ Fases da Lavagem } & Tempo (min) \\
\hline Primeiro enxágüe (Rinse) & 11 \\
Detergente & 15 \\
Enxágüe do detergente & 12 \\
Sanitizante & 13 \\
Enxágüe do sanitizante & 13 \\
\hline \multicolumn{1}{c}{ Total } & $\mathbf{6 4}$ \\
\hline
\end{tabular}

Para um maior detalhamento das características do efluente gerado nessa operação de lavagem, foi feito um acompanhamento da operação de limpeza dos componentes do sistema de secagem. A figura 9 ilustra o tanque que recebe as soluções de detergente, sanitizante e água filtrada. Pela figura observa-se que o descarte da água e soluções é feito por transbordamento do tanque de recirculação.

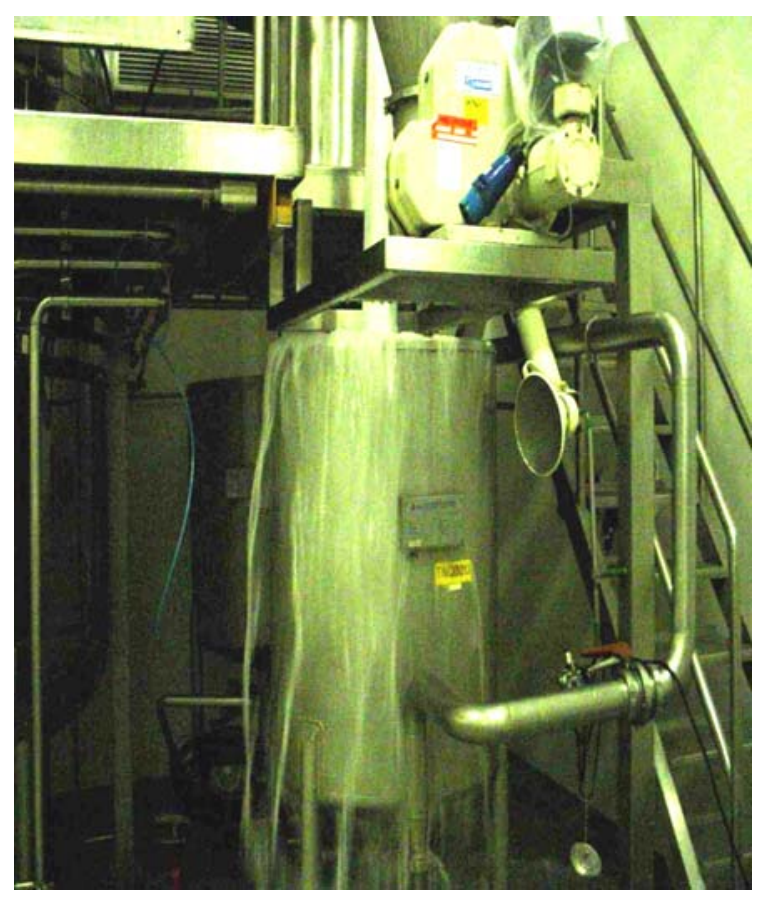

Figura 9 - Detalhe do tanque do sistema de limpeza e sanitização da unidade de secagem

Neste acompanhamento foram feitas coletas alternadas de amostras das lavagens no decorrer de cada etapa da lavagem e sanitização. No laboratório do Centro Internacional de Referência em Reúso de Água - CIRRA foi feita, a avaliação quantitativa do efluente das lavagens, analisando-se: condutividade, $\mathrm{pH}$ e turbidez. As tabelas 13, 14 e 15 apresentam os resultados obtidos. 
Tabela 13 - Tempos de coletas e variáveis analisadas no primeiro enxágüe (rinse)

\begin{tabular}{cccc}
\hline $\begin{array}{c}\text { Tempo } \\
(\mathbf{m i n})\end{array}$ & $\begin{array}{c}\text { Condutividade } \\
(\boldsymbol{\mu S})\end{array}$ & $\mathrm{pH}$ & $\begin{array}{c}\text { Turbidez } \\
(\mathbf{N T U})\end{array}$ \\
\hline 0 & 244 & 7,47 & 21,4 \\
2 & 256 & 7,33 & 56,0 \\
4 & 241 & 7,65 & 10,3 \\
10 & 232 & 7,35 & 7,3 \\
\hline
\end{tabular}

Tabela 14 - Tempos de coletas e variáveis analisadas no enxágüe do detergente

\begin{tabular}{cccc}
\hline $\begin{array}{c}\text { Tempo } \\
(\mathbf{m i n})\end{array}$ & $\begin{array}{c}\text { Condutividade } \\
(\boldsymbol{\mu S})\end{array}$ & $\mathbf{p H}$ & $\begin{array}{c}\text { Turbidez } \\
(\text { NTU) }\end{array}$ \\
\hline 0 & 249 & 8,00 & 1,01 \\
3 & 231 & 7,84 & 0,72 \\
6 & 228 & 7,52 & 0,59 \\
10 & 228 & 7,54 & 0,28 \\
\hline
\end{tabular}

Tabela 15 - Tempos de coletas e variáveis analisadas no enxágüe do sanitizante

\begin{tabular}{cccc}
\hline $\begin{array}{c}\text { Tempo } \\
(\mathbf{m i n})\end{array}$ & $\begin{array}{c}\text { Condutividade } \\
(\boldsymbol{\mu S})\end{array}$ & $\mathbf{p H}$ & $\begin{array}{c}\text { Turbidez } \\
(\mathbf{N T U})\end{array}$ \\
\hline 0 & 230 & 7,96 & 0,45 \\
5 & 232 & 7,84 & 0,39 \\
10 & 228 & 7,63 & 0,39 \\
\hline
\end{tabular}

Nota-se, na tabela 13 , que no primeiro enxágüe (rinse), no segundo minuto, devido à coleta no dreno de fundo do tanque de recirculação, os valores das variáveis analisadas apresentaram divergência em relação ao que era esperado, visto que o normal seria a redução da concentração dos contaminantes com o tempo. Isto ocorre também quando é analisada a condutividade. A figura 10 ilustra na forma gráfica, a variação dos valores de turbidez dos enxágües. 


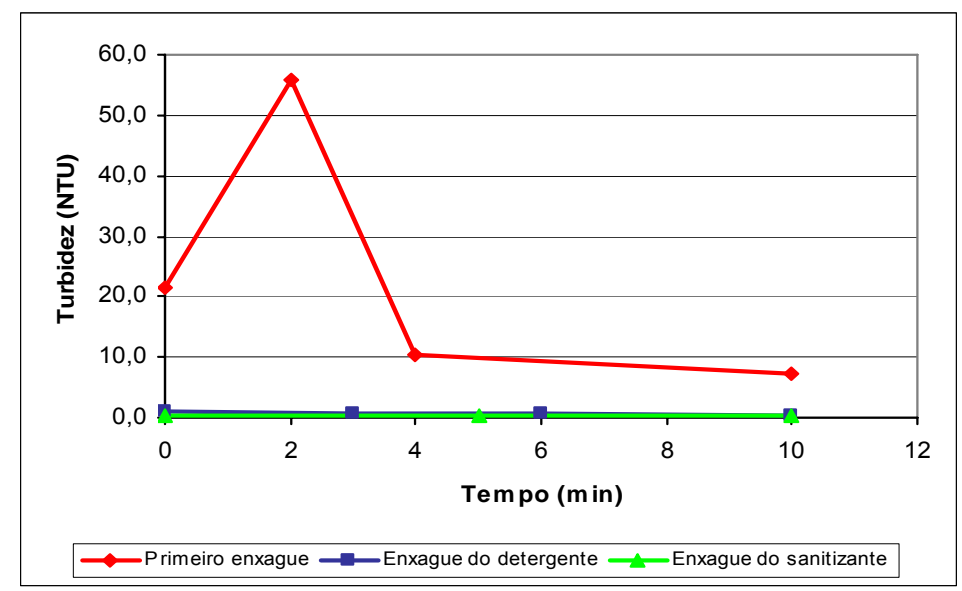

Figura 10 - Valores de turbidez dos enxágües em função do tempo de enxágüe das etapas de lavagem

Em relação ao pH nos processos de enxágüe não alteraram seu comportamento, como pode ser notado na figura 11, portanto, não é uma variável representativa para análise dos enxágües.

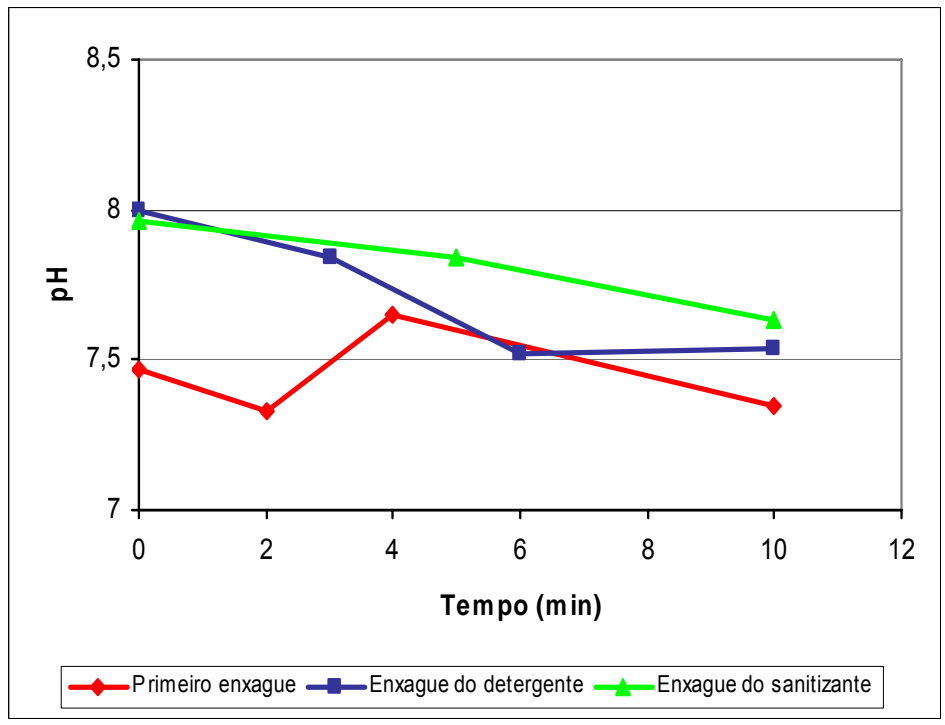

Figura 11 - Valores do pH em função do tempo de enxágüe das etapas de lavagem

No gráfico da figura 12, a condutividade a partir do sexto minuto, para os enxágües do detergente e do sanitizante, permanecem constantes, enquanto que para o primeiro enxágüe (rinse) esta condição ainda na ocorreu. 


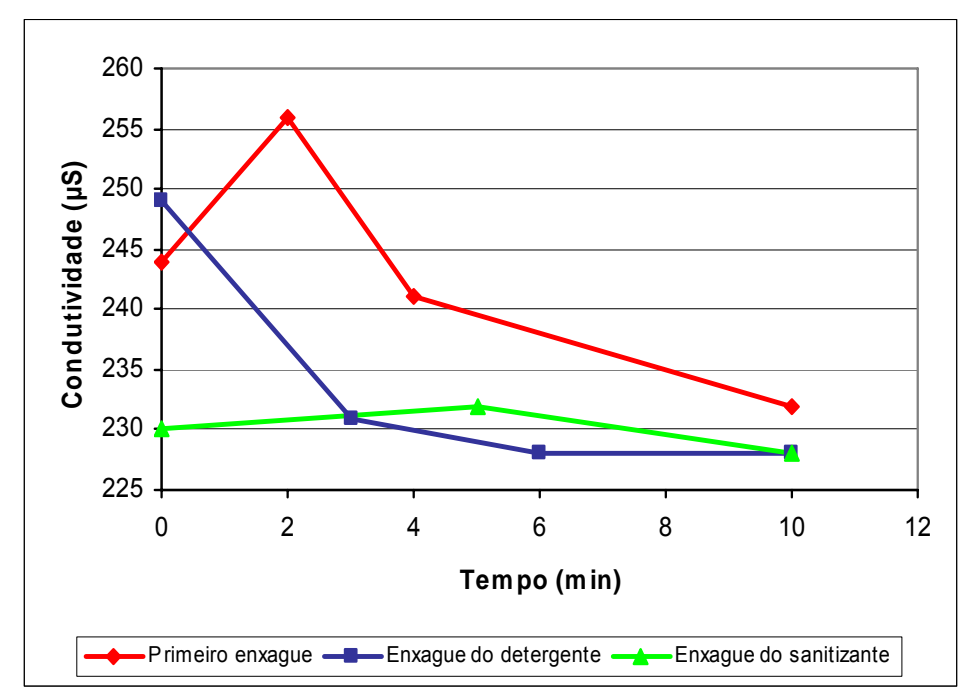

Figura 12 - Valores da condutividade em função do tempo de enxágüe das tapas de lavagem

Analisando os fluxogramas do sistema de secagem de emulsões, fornecidos pela Givaudan, nota-se que a bomba de água e das demais soluções de limpeza tem capacidade de $27 \mathrm{~m}^{3} / \mathrm{h}$, com uma recirculação de $2,0 \mathrm{~m}^{3} / \mathrm{h}$ da câmara de alimentação e uma bomba de recirculação do sistema móvel com capacidade de $25,0 \mathrm{~m}^{3} / \mathrm{h}$. Embora no fluxograma de instalação indique uma vazão de $25 \mathrm{~m}^{3} / \mathrm{h}$, constata-se que ocorre transbordo no tanque de recirculação, o que indica que a vazão pode ser menor.

No acompanhamento dos tempos de cada etapa do CIP, foi determinada, a demanda total de água por operação de lavagem é de, aproximadamente, $19 \mathrm{~m}^{3}$. Conforme informação do operador, em média são realizadas duas CIPs a cada dia, considerando-se que existem dois sistemas semelhantes, a demanda potencial de água neste processo é de $76 \mathrm{~m}^{3} / \mathrm{dia}$, conforme detalhado na tabela 16 .

Tabela 16 - Estimativa do consumo de água por operação de lavagem do sistema de secagem de emulsões.

\begin{tabular}{ccccc}
\hline \multicolumn{1}{c}{ Etapa } & $\begin{array}{c}\text { Tempo } \\
(\mathbf{m i n})\end{array}$ & $\begin{array}{c}\text { Vazão de } \\
\text { Descarte } \\
\left(\mathbf{m}^{\mathbf{3}} / \mathbf{h}\right)\end{array}$ & $\begin{array}{c}\text { Volume de } \\
\text { água } \\
\left(\mathbf{m}^{\mathbf{3}}\right)\end{array}$ & $\begin{array}{c}\text { Consumo } \\
\text { total } \\
\left(\mathbf{m}^{\mathbf{3}} / \mathbf{d i a}\right)\end{array}$ \\
\hline Primeiro enxágüe & 11 & 25 & 4,6 & 18,4 \\
Enxágüe detergente & 12 & 25 & 5,0 & 20,0 \\
Enxágüe sanitizante & 13 & 25 & 5,4 & 21,6 \\
Preparação de soluções & ---- & ---- & 4,0 & 16,0 \\
\hline \multicolumn{1}{c}{ Total } & --- & ---- & $\mathbf{1 9 , 0}$ & $\mathbf{7 6 , 0}$ \\
\hline
\end{tabular}




\subsubsection{Tanques móveis da área de aromas e essências}

Muitos dos aromas produzidos pela Givaudan são misturados em tanques móveis de diversos tamanhos, os quais são de fácil deslocamento. Estes tanques móveis, após a utilização para preparo dos aromas e essências são conduzidos para a área de lavagem, conforme mostra a figura 13, para que estes possam ser lavados e sanitizados.

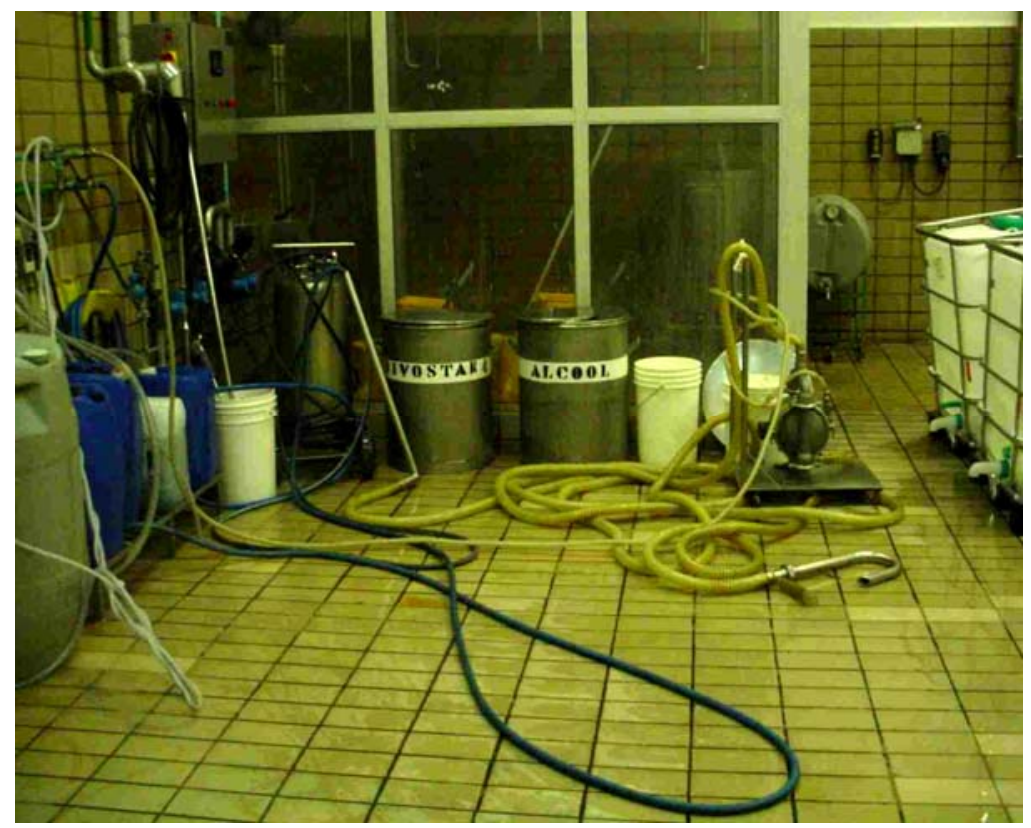

Figura 13 - Área de lavagem dos tanques móveis

O processo de lavagem destes tanques é feito usando mangueiras convencionais de $3 / 4$ ". O uso da água na lavagem primeiramente é utilizada para remoção da sujeira mais grosseira do tanque, para que possa ser realizada a lavagem com detergente e posteriormente para a remoção do detergente. As figuras 14 e 15 ilustram etapas da lavagem dos tanques móveis e os utensílios. 


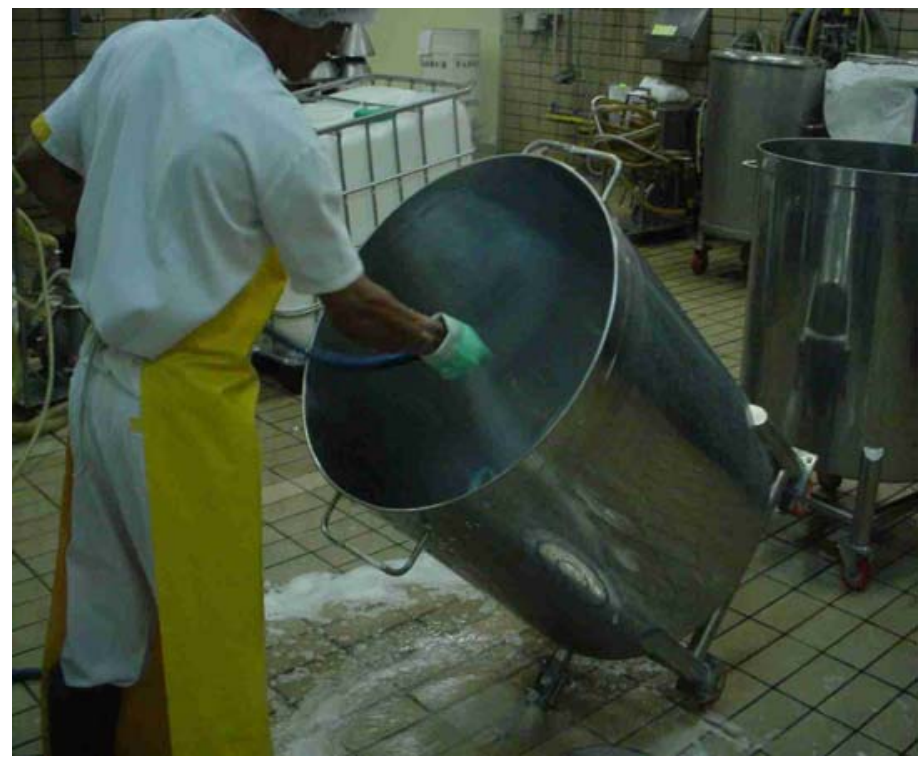

Figura 14 - Operação de enxágüe do detergente dos tanques móveis

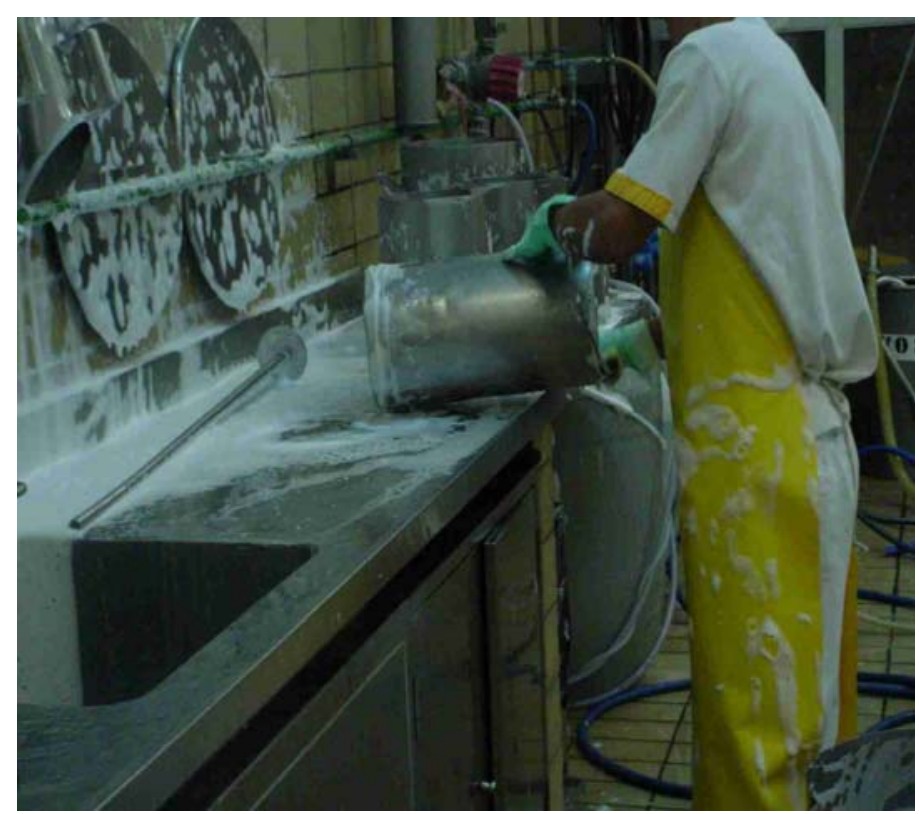

Figura 15 - Detalhe da lavagem de canecas sob a pia.

A lavagem destes tanques é manual e para uma melhor avaliação do consumo de água e, conseqüentemente, da geração de efluentes, o CIRRA em novembro de 2005, realizou a medição deste consumo instalando dois hidrômetros, um na saída de água quente (hidrômetro 7323) e outro na saída de água fria (hidrômetro 7320), para medir e determinar o consumo diário de água no local. Dessa forma, foi possível fazer uma comparação dos volumes gastos nesta área em relação ao consumo total da planta. 
Nas tabelas 17 e 18, são mostradas as leituras feitas diariamente no período de cinco dias úteis, para cada um dos hidrômetros instalados. Inicialmente no setor de aromas e posteriormente no setor das fragrâncias.

Tabela 17 - Valores lidos nos hidrômetros instalados nas lavagens dos tanques

móveis no setor de aromas

\begin{tabular}{ccc}
\hline Data & $\begin{array}{c}\text { Água fria: } \\
\text { Hidrômetro 7320 } \\
\text { (litros) }\end{array}$ & $\begin{array}{c}\text { Água quente: } \\
\text { Hidrômetro 7323 } \\
\text { (litros) }\end{array}$ \\
\hline $10 / 11 / 2005$ & 47 & 35,5 \\
$11 / 11 / 2005$ & 850 & 136 \\
$16 / 11 / 2005$ & 4.412 & 9.363 \\
$17 / 11 / 2005$ & 6.358 & 15.559 \\
$18 / 11 / 2005$ & 7.475 & 21.802 \\
\hline
\end{tabular}

Tabela 18 - Valores lidos nos hidrômetros instalados nas lavagens dos tanques

móveis no setor das fragrâncias

\begin{tabular}{ccc}
\hline Data & $\begin{array}{c}\text { Água fria: } \\
\text { Hidrômetro 7320 } \\
\text { (litros) }\end{array}$ & $\begin{array}{c}\text { Água quente: } \\
\text { Hidrômetro 7323 } \\
\text { (litros) }\end{array}$ \\
\hline $10 / 11 / 2005$ & 7.475 & 21.802 \\
$11 / 11 / 2005$ & 7.998 & 25.964 \\
$16 / 11 / 2005$ & 8.121 & 27.898 \\
$17 / 11 / 2005$ & 8.217 & 29.898 \\
$18 / 11 / 2005$ & 8.318 & 32.398 \\
\hline
\end{tabular}

Portanto, analisando-se as tabelas 17 e 18, consomem-se em média, nos setores de aromas e fragrâncias nas lavagens dos tanques móveis, aproximadamente, 9,43 $\mathrm{m}^{3} /$ dia e $2,25 \mathrm{~m}^{3} /$ dia respectivamente, totalizando $11,68 \mathrm{~m}^{3} /$ dia.

\subsubsection{Lavadores de gases}

Para o controle da emissão gasosa da área de secagem de emulsões a Givaudan conta com dois sistemas de lavagem de gases, os quais promovem a exaustão do ar existente no interior da fábrica conduzindo-o a um filtro tipo manga para remoção de material particulado, e posteriormente à torre de lavagem antes de lançá-lo à 
atmosfera. As figuras 16 e 17 apresentam o filtro manga e a torre de lavagem respectivamente.

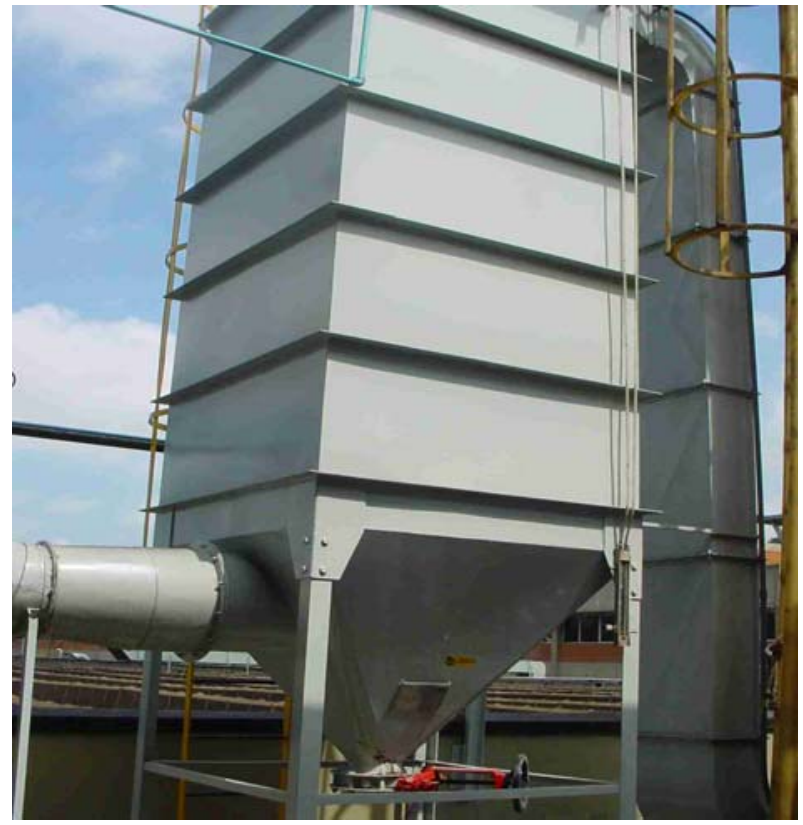

Figura 16 - Filtro tipo manga

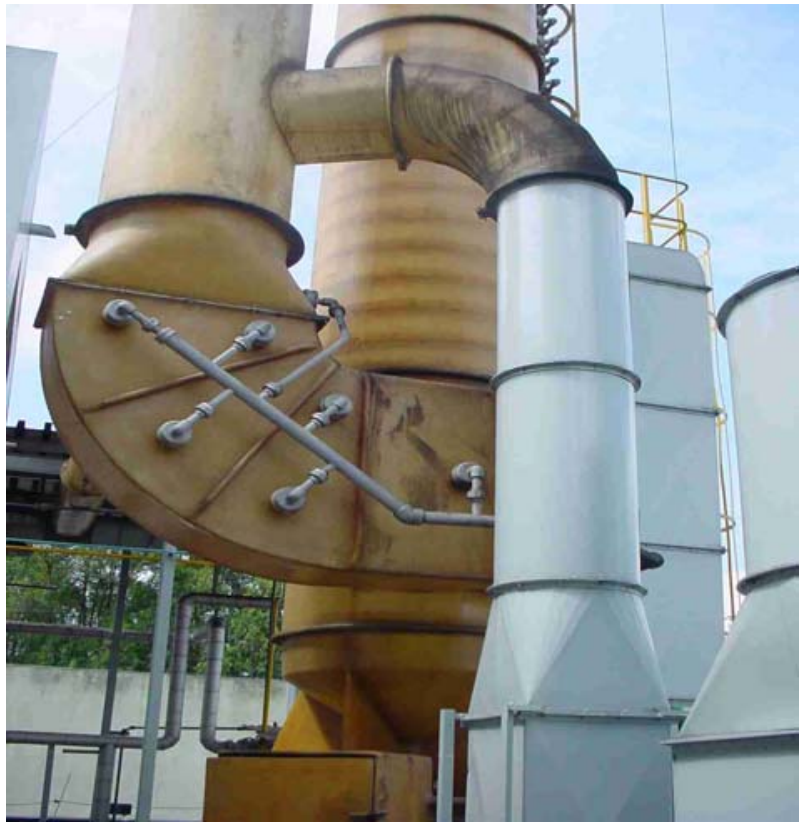

Figura 17 - Torre de lavagem de gases

A água, proveniente da rede é recircula com auxílio de duas bombas e, em média, duas vezes por semana, todo volume contido nos lavadores é descartado. 
Os reservatórios possuem as seguintes dimensões: diâmetro 1,50 m e 1,59 m de altura, totalizando um volume de $2,81 \mathrm{~m}^{3}$. Com isso, a demanda de água para esta atividade é de $1,50 \mathrm{~m}^{3} / \mathrm{dia}$.

\subsubsection{Vasos sanitários}

Durante uma das visitas foi realizado um teste em um dos vasos sanitários e concluiu-se que seu sifonamento, para limpeza completa, ocorre com uma vazão de cerca de doze litros por acionamento.

A estimativa do consumo de água em vasos sanitários, uma informação importante, está relacionada ao número de funcionários, distinguindo-se 169 homens e 122 mulheres. Para efeito de cálculo, foi considerado que a metade dos banheiros masculinos tinha mictórios e a outra metade não dispõem. Sendo assim, 207 funcionários utilizam as bacias sanitárias e outras 85 pessoas, no caso homens, utilizam os mictórios. Portanto, o resultado representa apenas uma estimativa, os vasos sanitários são utilizados três vezes por dia por funcionário, em um período de oito horas. Sabe-se, também que mictórios têm um consumo médio de 1,5 litros de água por acionamento. Vale lembrar que no setor da produção seu funcionamento é durante três períodos ininterruptos por dia, o que pode levar ao aumento destas vazões estimadas, entretanto, estas não foram consideradas. O consumo de água pelas bacias sanitárias e pelos mictórios é mostrado na tabela 19.

Tabela 19 - Estimativa de consumo de água nos vasos sanitários

\begin{tabular}{ccccc}
\hline Aparelho & $\begin{array}{c}\text { Volume por } \\
\text { acionamento (litros) }\end{array}$ & $\begin{array}{c}\mathbf{N}^{\circ} \text { de } \\
\text { acionamentos/dia }\end{array}$ & $\begin{array}{c}\mathbf{N}^{\circ} \text { de } \\
\text { usuários }\end{array}$ & $\begin{array}{c}\text { Volume } \\
\text { (litros/dia) }\end{array}$ \\
\hline Válvula de descarga & 12,0 & 3 & 207 & $7.452,0$ \\
Mictórios & 1,5 & 3 & 85 & 382,5 \\
\hline Total & $-\ldots--$ & $-\ldots$ & 292 & $7.834,5$ \\
\hline
\end{tabular}

\subsubsection{Irrigação}

A irrigação de áreas verdes na Givaudan, ilustrada na figura 18 conforme informado pela equipe de manutenção, é feita duas vezes por semana com auxílio de aspersores ou, em alguns casos por mangueiras comuns. 


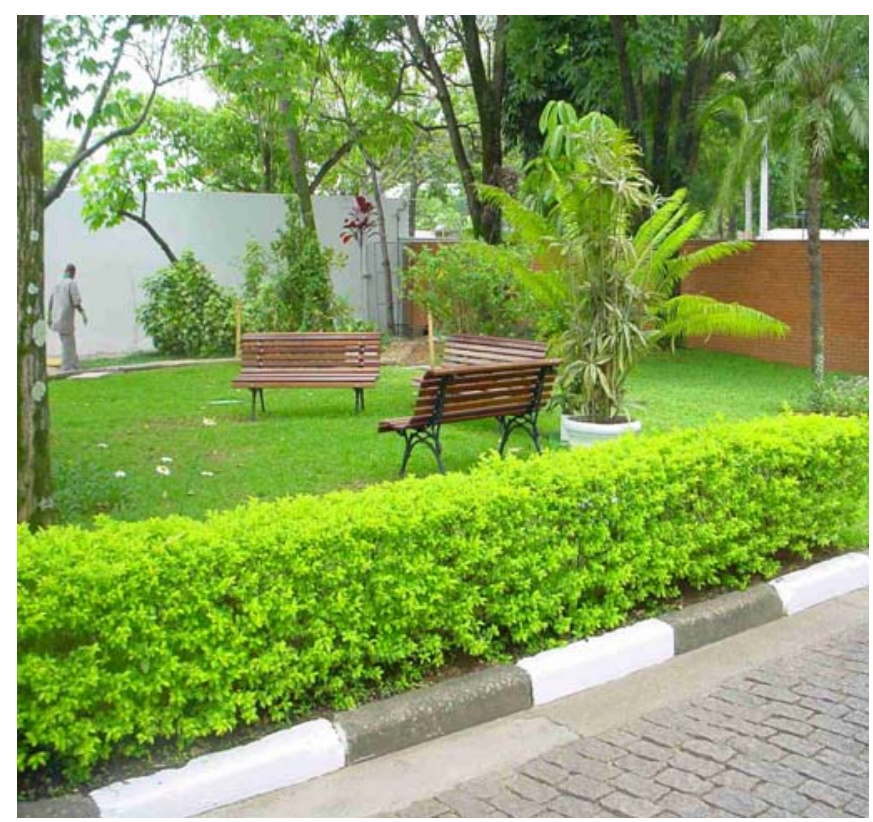

Figura 18 - Vista da praça irrigada

Foi possível estimar um consumo médio de água para esta atividade. As áreas irrigáveis atualmente perfazem um total de 7.345,15 $\mathrm{m}^{2}$, entretanto, foi informado que uma área de 598,21 $\mathrm{m}^{2}$ será utilizada para construção de um galpão, portanto, restarão $6.747,15 \mathrm{~m}^{2}$. Através de uma estimativa ponderada de demanda de água por área irrigada, chegou-se nos valores mostrados na tabela 20.

Tabela 20 - Estimativa do consumo de água nas irrigações

\begin{tabular}{ll}
\hline Área total irrigada & $6.747,15 \mathrm{~m}^{2}$ \\
Vazão média das torneiras & $0,25 \mathrm{l} / \mathrm{s}$ \\
Tempo de irrigação por área & $0,071 \mathrm{~min} . \mathrm{m}^{2}$ \\
$\mathrm{~N}^{\circ}$ de irrigações por semana (7 dias) & 2 vezes \\
Tempo mensal de irrigação & $4106 \mathrm{~min} . / \mathrm{mês}$ \\
Consumo médio para irrigação & $2,05 \mathrm{~m}^{3} / \mathrm{dia}$ \\
\hline
\end{tabular}

\subsection{Potencial para reúso de água na empresa}

A escolha do processo de tratamento não é uma tarefa fácil; a seleção de um método apropriado depende das exigências do reúso. É lógico que antes de propor qualquer tratamento obrigatoriamente se devem realizar análises da qualidade do 
efluente e definir qual o novo uso pretendido para a água tratada, devendo ter em consideração as especificações da indústria de alimentos.

Para propor um sistema de reúso de água na Givaudan, destaca-se que a sua solução deve ser específica em função das diversas atividades nos processos envolvidos na área da produção de aromas e fragrâncias, tendo em consideração os maiores consumos da água nas operações de lavagem dos equipamentos e utensílios nas áreas especificamente da secagem de emulsões e tanques móveis.

A proposta é que a água utilizada no processo de lavagem CIP, seja reusado internamente no processo da lavagem dos equipamentos nos secadores do tipo Spray Dryer na área de secagem de emulsões, a qual estará apoiada pela ferramenta APPCC que vai garantir a qualidade da água, a operação de limpeza é ilustrada na figura 19.

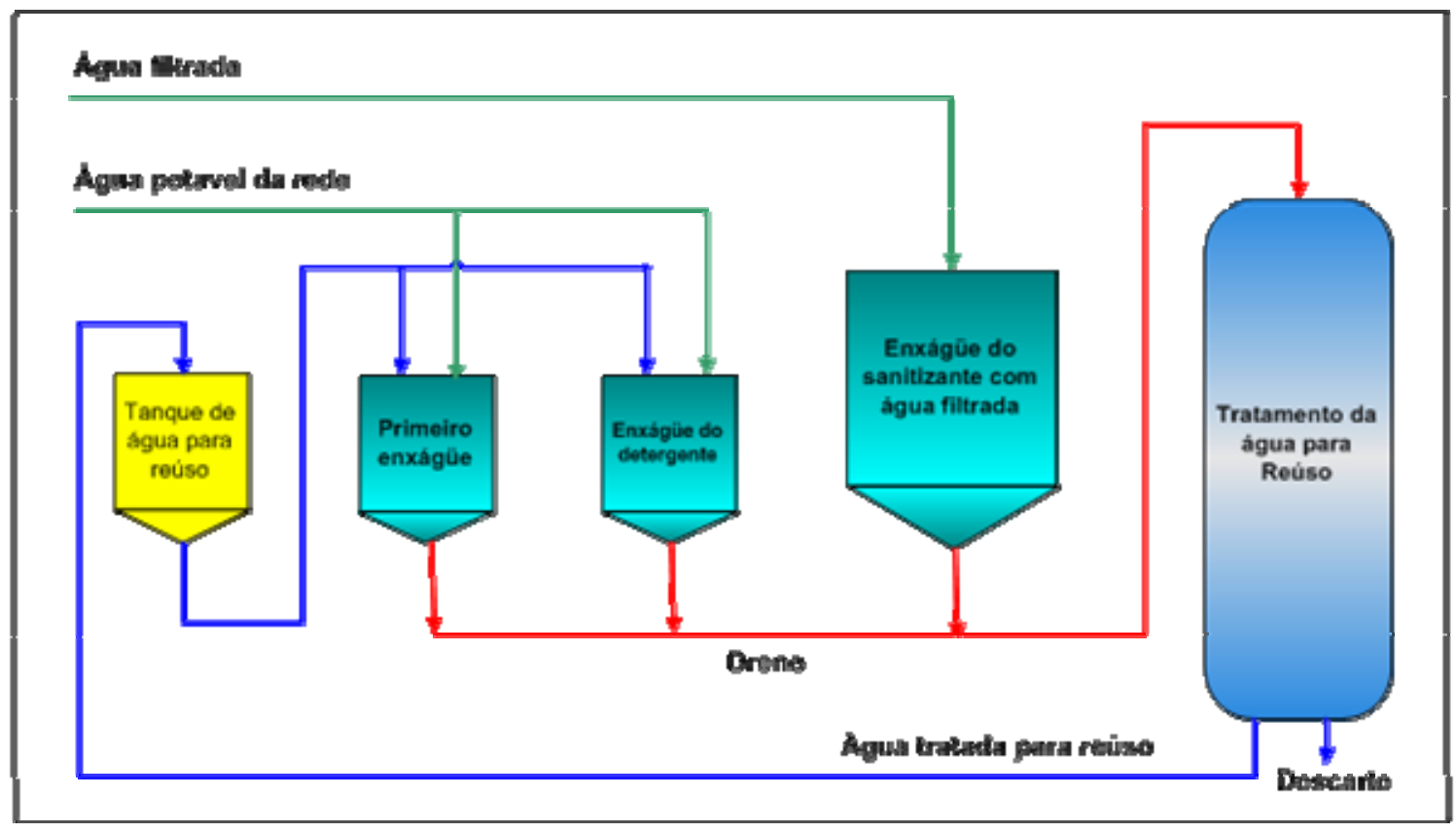

Figura 19 - Esquema do programa de reúso de água na área de lavagem

O uso de água nas operações de lavagem será otimizado, pois a água depois do tratamento será levada a um tanque de armazenamento para ser reusado nos dois próximos estágios de lavagem e enxágüe, removendo o residual da essência em pó que estava sendo produzida. Os equipamentos sempre são higienizados e deixados operativos para a próxima campanha de produção. 


\subsubsection{Aplicação do sistema APPCC no reúso de água}

O sistema APPCC pretende programar o controle de todas as etapas do programa de reúso de água em que há perigos de contaminação, desde o início do processo de lavagem até obter a água tratada a ser reutilizada na posterior lavagem dos equipamentos na preparação das emulsões, prevenindo problemas e elevando a segurança da qualidade da água. Portanto, o modelo baseado no APPCC foi elaborado de maneira descritiva a fim de implementar e avaliar o reúso de água na área de produção de aromas e fragrâncias da Givaudan.

A fim de obter um sistema seguro de reúso de água é necessário uma implementação prévia dos programas de pré-requisitos. Ele está focado em informações especificas da qualidade da água, dos perigos e riscos associados ao reúso no processo de lavagem. Assim sendo, deve conter uma listagem dos patógenos microbiológicos potenciais e os possíveis métodos de tratamento da água.

Após a implementação das etapas preliminares, são aplicados os sete princípios do sistema APPCC. As seguintes etapas ou princípios fornecem um modelo de APPCC para reúso de água em cada processo da lavagem na área de emulsões por secadores do tipo Spray Dryer.

Para cada caso específico de reúso de água, é necessário realizar análises da água para determinar os microorganismos perigosos relevantes (bactérias, vírus, protozoários e helmintos), que podem ter estado no contato com água antes de ser usados para reúso. Por exemplo, o hipoclorito não é recomendado para o tratamento de água para limpeza dos equipamentos e utensílios por ter contato direto com o produto a ser processado, e em muitos casos pode produzir a formação de substâncias cancerígenas.

A caracterização microbiológica da água proveniente do processo de lavagem é um instrumento de apoio. Após a identificação, os perigos potenciais são listados e agrupados de acordo com propriedades comuns como sua temperatura mínima do crescimento ou sua sensibilidade aos métodos de tratamento da água. 
A realização de um tratamento biológico não é o adequado em virtude da presença de microorganismos no efluente final do tratamento o qual não é apto para o posterior reúso interno na lavagem dos equipamentos e utensílios na preparação das emulsões.

Como os efluentes da operação de lavagem do secador Spray Dryer contem uma alta concentração de sólidos dissolvidos, o tratamento recomendado para este tipo de efluente é através da osmose reversa por ser um processo utilizado para remover solutos de baixo peso molecular, tais como sais dissolvidos, compostos orgânicos, colóides, de um solvente, tipicamente a água.

A osmose reversa é um fenômeno natural que ocorre quando duas soluções de diferentes concentrações são separadas por uma membrana semipermeável, ou seja, permeável para solventes (água pura) e impermeável para solutos (sais dissolvidos). A água flui naturalmente através da membrana no sentido da solução menos concentrada para a mais concentrada devido à diferença de pressão osmótica, que é maior para a solução mais concentrada. O fluxo natural cessa quando as duas soluções estiverem com a mesma concentração, ou s eja, quando tiver sido atingido o equilíbrio osmótico. As membranas de osmose apresentam poros com diâmetro menor que 0,001 $\mu \mathrm{m}$. Geralmente, a pressão utilizada varia de 3,4 a valores próximos de 80 bar. A osmose reversa, não deixa passar por suas membranas bactérias e vírus, agindo assim, também, como desinfetante. Os vírus e as bactérias têm maiores tamanhos, que a abertura da membrana de osmose reversa, que os retém, e neste caso, atua como coletor para estes elementos.

A figura 20 apresenta um diagrama de blocos da seqüência de operações e processos no tratamento do efluente utilizando-se osmose reversa. 


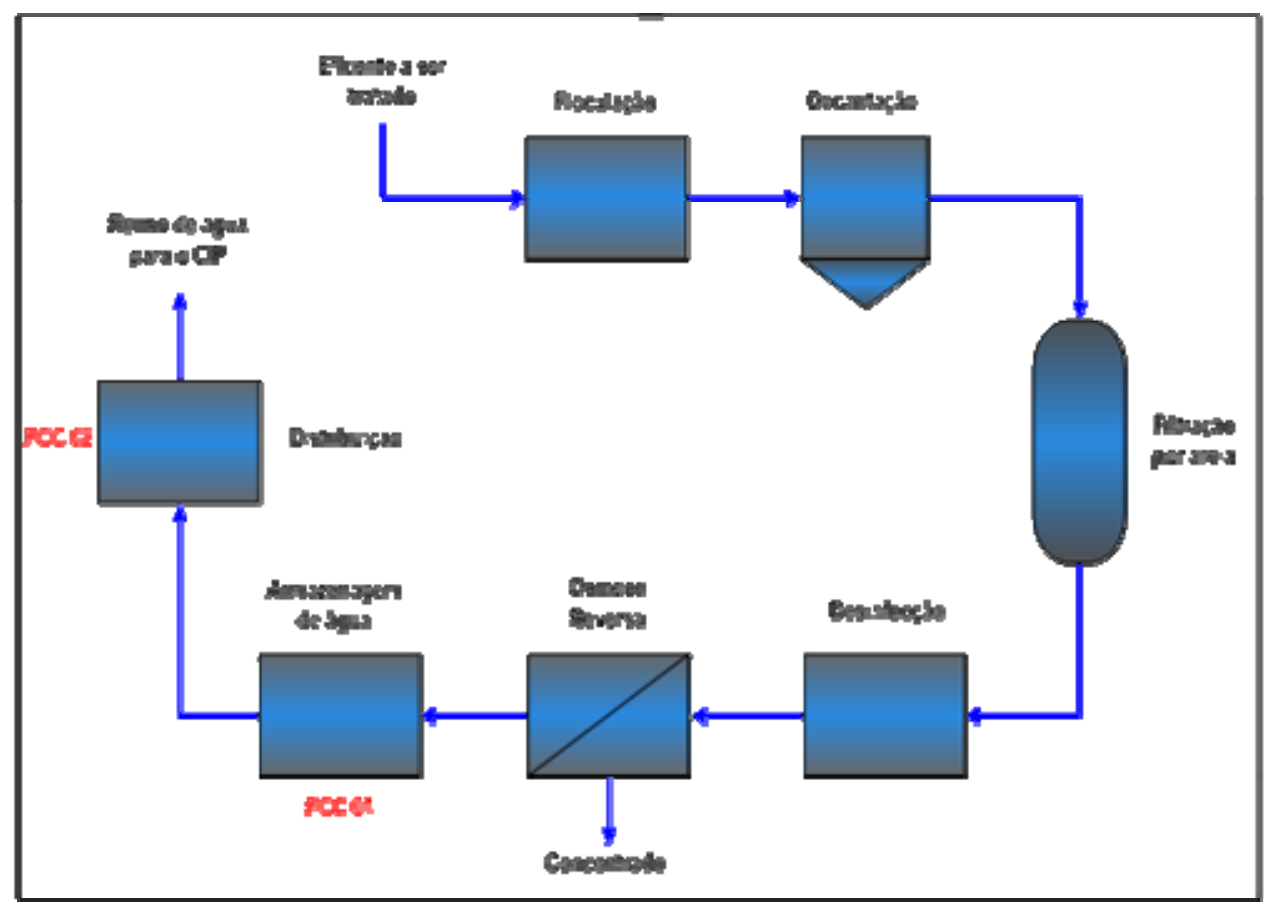

Figura 20 - Diagrama de bloco do tratamento do efluente por osmose reversa

Os processos de tratamento estão fundamentados na operação de sistemas físicoquímicos de floculação-decantação, seguidos de tratamento por filtração em areia, desinfecção, e osmose reversa. O efluente tratado por osmose reversa apresenta uma taxa de remoção de sólidos dissolvidos de 95\%, e de uma taxa de recuperação da água, aproximadamente de $75 \%$.

O tratamento da água para reúso é considerado como um PC (ponto crítico), desde que esta etapa pretenda eliminar ou reduzir os perigos aos níveis aceitáveis. O PC é uma etapa decisiva antes do reúso; os fatores a ter em consideração são as maneiras pela qual a água é coletada e transportada ao lugar onde será reusado, o tempo, e a temperatura em que a água é mantida a fim de estabelecer-se este ponto é crítico,

A identificação dos PCCs deve ser feita de uma forma estruturada e sistemática, efetuada com base na análise e identificação de perigos e a probabilidade de ocorrência de contaminação, inaceitável nas operações a que o produto está sujeito durante o processamento. A figura 21 apresenta a detecção dos PCs e PCCs no processo produtivo. 


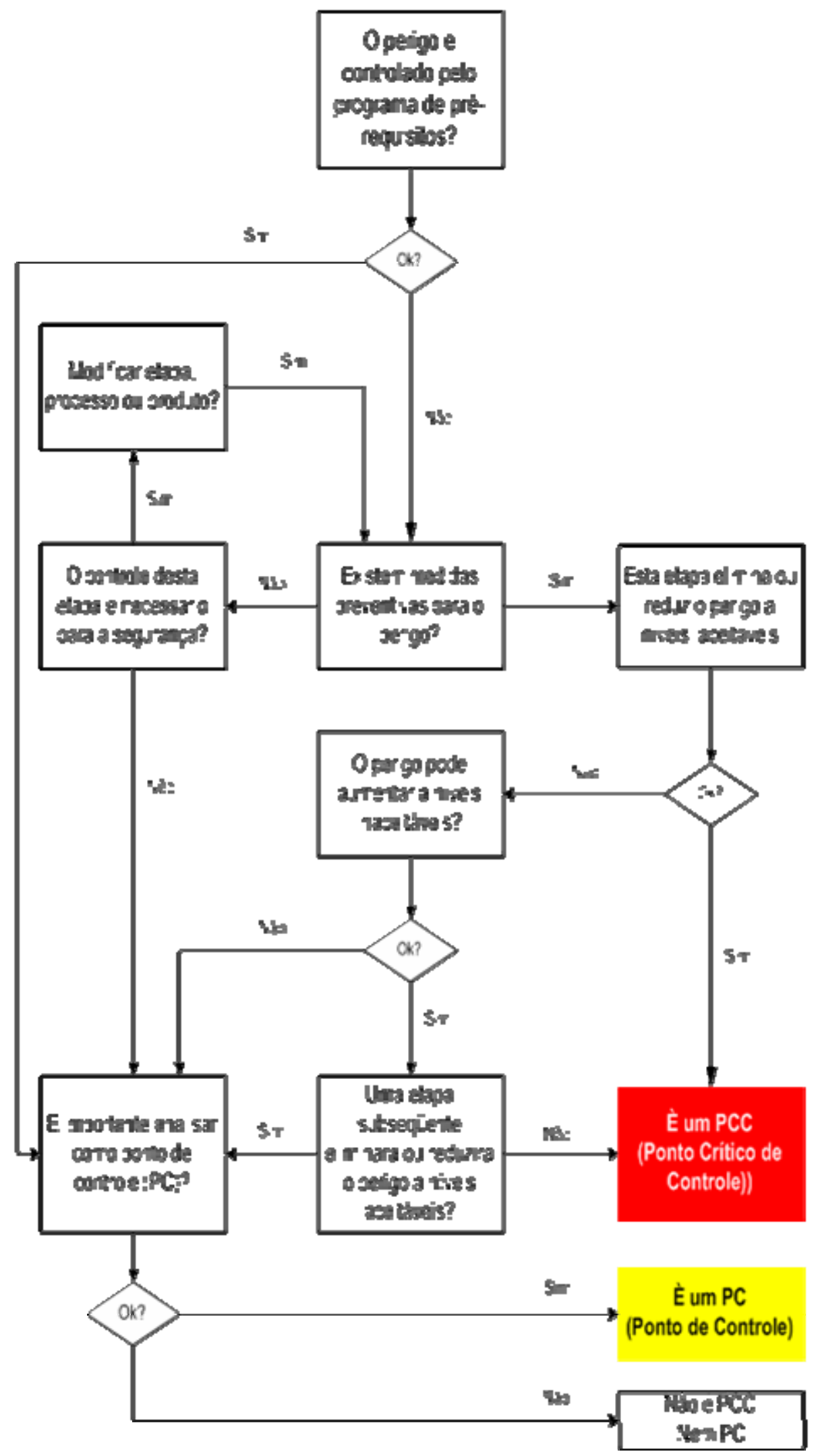

Figura 21 - Detecção do PCC no processo produtivo. 
A distribuição e armazenamento da água para reúso são considerados como um PCCs, desde que as medidas de controle podem ser aplicadas a fim de evitar um aumento das ocorrências dos perigos. A água tratada deve ser reusada o mais rápido possível após a coleta, de modo que esta não sofra alteração na qualidade. Se o armazenamento for prolongado, deve-se controlar a temperatura da água, a fim evitar o crescimento de microorganismos. È importante projetar programas de manutenção contínuos das válvulas hidrostáticas, e bombas de pressão para uma ótima distribuição da água a reusar.

A figura 22 apresenta o fluxograma da lavagem dos equipamentos de secagem do tipo Spray Dryer na área de emulsões, no qual foram determinados os PC e os PCCs.

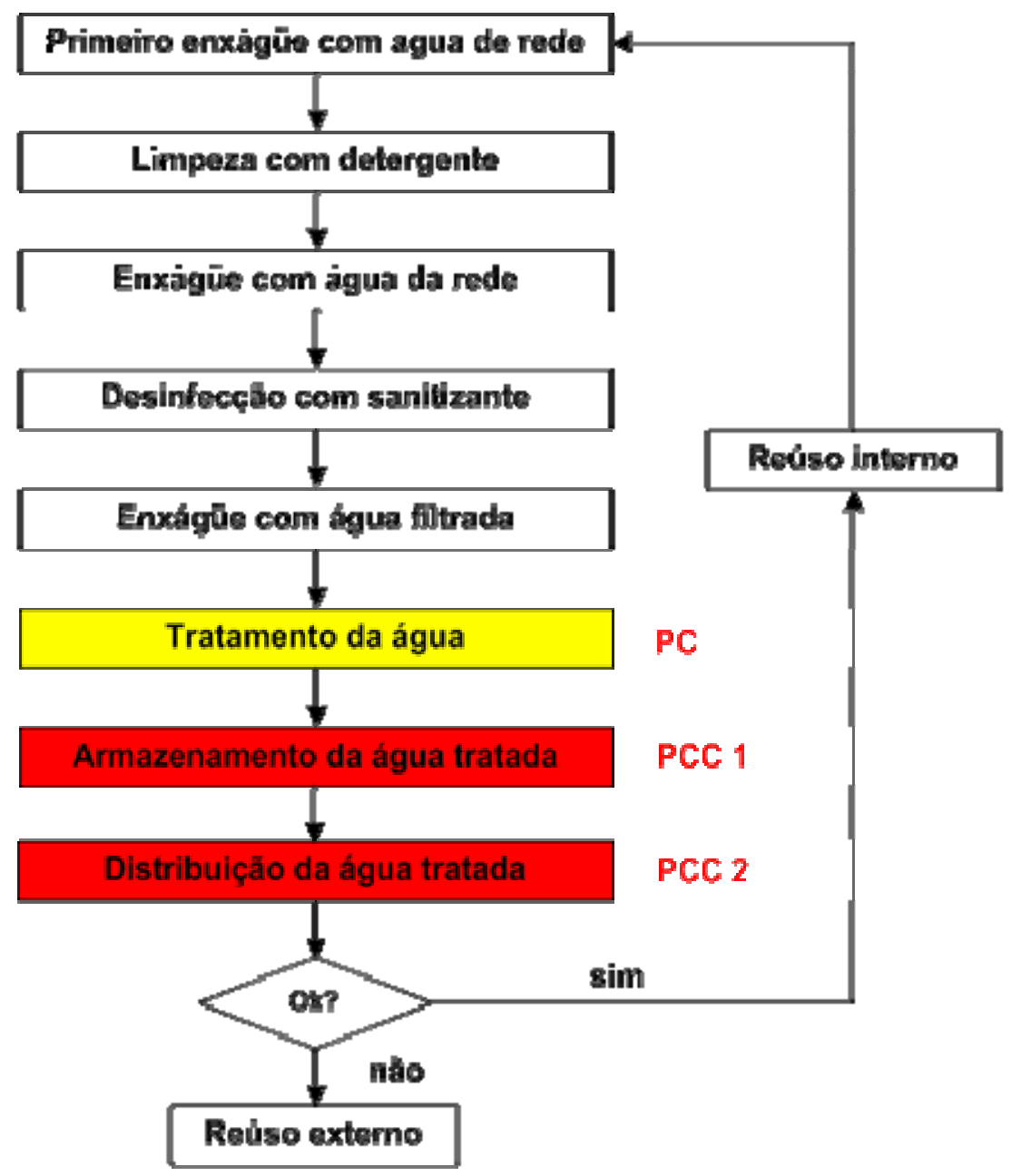

Figura 22 - Fluxograma de lavagem do secador do tipo Spray Dryer 
Após a identificação dos PCCs, se estabelecem os limites críticos para a avaliação dos riscos de acordo com referências disponíveis na literatura especializada, conceitos e bom senso. Deve ser considerada uma grande variedade de microrganismos e substâncias químicas, para cada perigo potencial.

Cada PCC tem uma ou mais medidas que devem ser corretamente controladas, cada medida preventiva tem limites críticos que indicam se uma operação esta sob o controle em um PCC particular. Outras medidas de controle tais como a turbidez ou as contagens das partículas são recomendadas a fim assegurar a segurança do tratamento do efluente que será reusado na lavagem dos equipamentos por meio de todo o processo de osmose reversa.

Como medida de controle do risco para o processo de tratamento do efluente da água para reúso, deve-se considerar um enxágüe com água filtrada no final do processo de lavagem dos equipamentos.

No armazenamento e distribuição da água para reúso no processo de lavagem dos equipamentos, tem que incluir como medida de controle o tempo, concentração do residual e a temperatura.

O monitoramento dos PCCs, com vistas à verificação do cumprimento dos limites críticos é relacionando os PCCs com os resultados das análises microbiológicos do processo. Devendo-se, definir as medidas rotineiramente identificando os principais problemas da qualidade da água, elaborando um plano de monitoramento; e definindo os pontos de amostragem para avaliar modificações significativas na qualidade da água tratada para reúso.

Os parâmetros que definem a qualidade microbiológica no reúso da água são definidos pelos limites críticos atribuídos para cada parâmetro no sistema de monitoração. Estes valores devem ser ajustados nos níveis que não asseguram nenhum risco para a saúde humana.

As alterações na qualidade da água podem ser provocadas pelos impactos na fonte de captação da água nos poços subterrâneos, problemas ocorridos no sistema de 
tratamento; recontaminação ocorridas na armazenagem e distribuição da água até a área de lavagem.

Caso algum limite crítico seja ultrapassado deve-se estabelecer ações corretivas, através de intervenções nos fluxogramas de produção, precisa-se elaborar as possíveis medidas corretivas.

A documentação de todas as atividades desenvolvidas na implantação do sistema APPCC no reúso de água, tem que ser registrado todos os dados referentes à identificação e monitoramento dos PCCs, limites críticos adotados e ações corretivas e preventivas;

A verificação e avaliação periódica do funcionamento de todo o sistema, é através de medidas que confirmem o funcionamento adequado do mesmo por meio de testes realizados no início e final da implementação completa do sistema.

A implantação do reúso de água apoiada pela ferramenta APPCC na área de lavagem do CIP, após o sistema de tratamento por osmose reversa $(75 \%$ de recuperação da água), teria uma redução potencial no consumo total de água de aproximadamente 42.6\%. A tabela 21 apresenta o consumo de água após o tratamento por osmose reversa.

\begin{tabular}{lcc}
\hline \multicolumn{1}{c}{ Processos } & $\begin{array}{c}\text { Consumo total de } \\
\left.\text { água ( } \mathbf{m}^{\mathbf{3}} / \mathbf{d i a}\right)\end{array}$ & $\begin{array}{c}\text { Osmose Reversa } \\
\text { recuperação da água } \\
\mathbf{( 7 5 \% )}\end{array}$ \\
\hline Lavagem do Spray Dryer & 76,0 & 19.0 \\
Lavagem dos tanques moveis & 11,68 & 11,68 \\
Lavadores de gases & 1,50 & 1,50 \\
Maquina de lavar roupas & 0,20 & 0,20 \\
Irrigação de áreas permeáveis & 1,92 & 1,92 \\
Vasos sanitários & 7,83 & 7,83 \\
Lavagem de pisos & 0,21 & 0,21 \\
\hline \multicolumn{1}{c}{ Total } & $\mathbf{9 9 , 3 4}$ & $\mathbf{4 2 , 3 4}$ \\
\hline \multicolumn{2}{c}{}
\end{tabular}

Tabela 21 - Estimativa do consumo de água aplicando tratamento por osmose reversa 


\subsubsection{Ações complementares para redução do consumo da água}

Para reduzir o consumo de água na empresa se propor implantar é instalar uma estação de tratamento biológico para adequar o efluente proveniente da área de secagem de emulsões, lavagens dos tanques moveis, lavadores de gases, vasos sanitários, e bebedouros. Os sistemas de tratamento empregados são compostos basicamente de unidades de sedimentação natural, filtração simples e desinfecção com cloro ou com luz ultravioleta.

Na figura 23 se ilustra o fluxograma dos possíveis reúsos externos não potáveis. Os usos potenciais seriam; torres de lavagem de gases, sistemas de ar-condicionado, descargas de vasos sanitários, irrigação de áreas verdes, lavagens de pisos e carros e reserva para controle de incêndio.

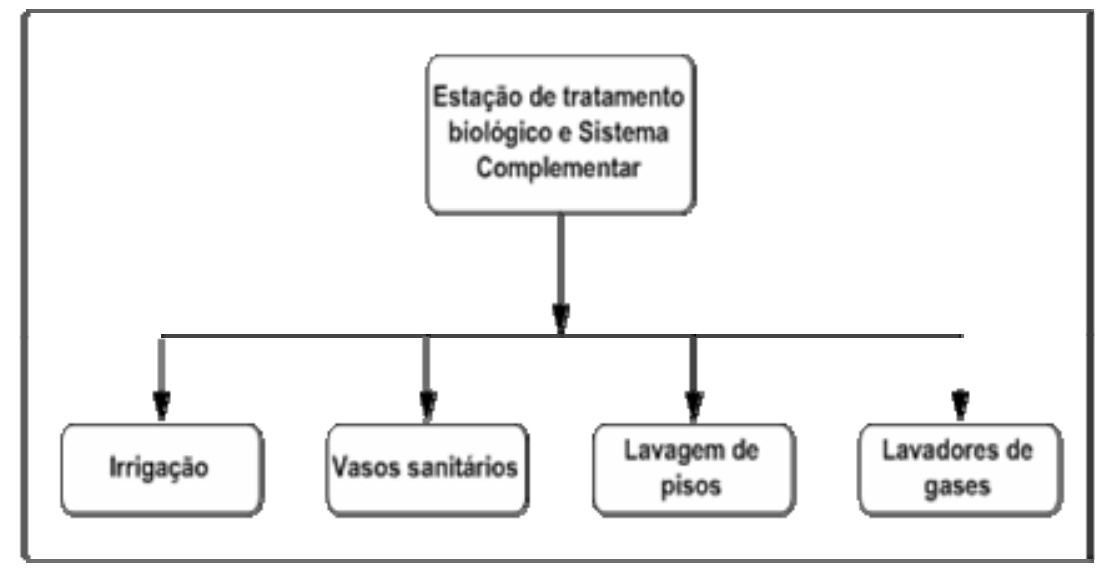

Figura 23 - Fluxograma de reúso para usos externos

Além da instalação do sistema biológico para tratamento do efluente, devem ser previstas linhas independentes de distribuição e reservatórios de armazenagem. 


\section{CONCLUSÕES}

Com base nos objetivos propostos e nos resultados obtidos no desenvolvimento do estudo de caso apresentado, pôde-se chegar às seguintes conclusões:

$\mathrm{Na}$ busca das potenciais aplicações de reúso de água se propor fazer o tratamento da água utilizando osmose reversa, após o processo de lavagem dos tanques Spray Dryer na área de secagem de emulsões, a qual será apoiada pela aplicação do sistema APPCC como ferramenta de qualidade, o reúso pretendido será realizado no primeiro e segundo enxágüe.

O sistema de tratamento recomendado foi utilizando é a través de osmose reversa, por ser um processo que remove as altas concentrações dos sólidos dissolvidos através de uma membrana semipermeável. Após o tratamento por osmose reversa com uma retenção da água de $75 \%$, poderia ter uma redução do consumo total da água de $42.6 \%$ aproximadamente.

Uma ação complementar para a redução do consumo de água consiste em instalar uma estação de tratamento biológico para os efluentes provenientes da área de lavagem dos utensílios, tanques moveis, lavadores de gases, e vasos sanitários na área de secagem de emulsões. O reúso pretendido desta água tratada será aplicado para fines menos nobres como descargas de vasos sanitários, irrigação de áreas verdes, lavagens de pisos e carros, e para controle de incêndio.

Para cada tipo de reúso devem ser avaliados os equipamentos e tecnologias mais apropriados, dentre as diversas opções existentes, ressaltando-se que uma determinada configuração tecnológica pode ser excelente para uma implantação específica e totalmente inadequada para outra.

Os valores dos parâmetros de $\mathrm{pH}$ não alteraram seu comportamento e a condutividade a partir do sexto minuto, para os enxágües do detergente e sanitizante permanecem constantes mais no primeiro enxágüe esta condição varia. 
O maior risco associado ao programa de reúso é na qualidade microbiológica, a qual deve ser garantida e monitorada o tempo todo, sendo, portanto imprescindível o uso de analise de perigos e pontos críticos de controle.

Outro fator importante para implantação do sistema APPCC foi a caracterização e análise da composição física, química e principalmente microbiológica do efluente da área de lavagem, visto que o tipo de tratamento selecionado é em função tanto da qualidade da água coletada como do uso pretendido.

O tratamento de água para reúso é considerado como um Ponto Crítico, porque esta etapa pretende eliminar ou reduzir os perigos a níveis aceitáveis. As etapas de distribuição e armazenamento da água para reúso são consideradas Pontos Críticos de Controle. Estes devem ser constantemente controladas.

Como medida de controle de risco para processos de tratamento do efluente de água, deve-se considerar o último enxágüe com água filtrada. $E$ importante estabelecer as medidas corretivas e a documentação de todas as atividades desenvolvidas na implementação do sistema APPCC.

Apesar do grande potencial do reúso de água em plantas de processamento de alimento, encontrou-se uma grande limitação para a realização desse trabalho devido à escassa literatura por tratar-se de uma preocupação relativamente recente no meio industrial As indústrias de alimentos que estão planejando a implantação do reúso de água apoiados pela ferramenta APPCC armazenam as suas informações na própria empresa, e não divulgam facilmente. 


\section{RECOMEDAÇÕES}

Recomenda-se a aplicação da ferramenta APPCC na implantação de programas de reúso de água nos diversos setores da indústria de alimentos por ser de extrema relevância na segurança da qualidade da água, a qual contribui a minimização dos problemas associados à escassez de água.

Os estudos de novas tecnologias de tratamento dos efluentes aplicando a ferramenta de APPCC na indústria de alimento no setor de aromas e essências devem ser desenvolvidos e divulgados favorecendo a adoção de reúso em diversos setores do processo produtivo.

$\mathrm{Na}$ hora de tomar a decisão de implantar o sistema APPCC como ferramenta no reúso de água, deve estar vinculado um estudo mais aprofundado das características do efluente gerado na área da lavagem, para a obtenção do máximo potencial de reúso e também dos procedimentos para a sua viabilização.

É recomendável que o tema da dissertação seja objeto de futuros estudos mais aprofundados, a fim de que os diversos segmentos da indústria de alimentos tenham a oportunidade de refletir e buscar mecanismos de reúso a ser aplicados após os processos produtivos evitando-se misturar esses efluentes com o esgoto da empresa. 


\section{REFERÊNCIAS}

ATHAYDE, A. Sistemas GMP e HACCP garantem produção de alimentos inócuos. Engenharia de Alimentos, v. 5, n. 23, p. 13-17, jan./fev. 1999.

ASSOCIAÇÃO BRASILEIRA DE NORMAS TÉCNICAS. NBR ISO 9000:2000: sistemas de gestão da qualidade: fundamentos e vocabulário. Rio de Janeiro, 2000. $34 \mathrm{p}$.

BELLENZANI, J. R. Descrição de sistema da qualidade para a indústria de produtos derivados de carne. 2004. 71 p. Dissertação (Mestrado) - Universidade Estadual de Campinas, Campinas, 2004.

BLUM, J. R. C. Critérios e padrões de qualidade da água. In: MANCUSO, P.C.S.; SANTOS, H.F. (Ed.). Reúso de água. São Paulo: Manole, 2003. p. 125-174.

CASANI, S; KNOCHEL, S. Aplication of HACCP to water reuse in the food industry. Food Control, Guildford, v. 13, n.4/5, p. 315-327, jun./jul. 2002.

CASANI, S; ROUBANY, M; KNOCHEL, S. A discussion paper on challenger and limitations to water reuse and hygiene in the food industry. Water Research, v., 39. p. 1134-1146, 2004.

CHAVES, J. B. Controle de qualidade na indústria de alimentos. Viçosa, MG: UFV, 1998. 55 p. Apostila de aula, da disciplina do professor José Benício Chaves da Universidade Federal de Viçosa. Departamento de Tecnologia de Alimentos.

CODEX ALIMENTARIUS. Rome, Italy. Disponível em:

<http://www.codexalimentarius.net>. Acesso em: 22 mar. 2006.

COMITÉ CODEX ALIMENTARIUS DO BRASIL. Programa Conjunto da Organização das Nações Unidas para a Agricultura e a Alimentação. Disponível em: <http://www.inmetro.gov.br/qualidade/comites/ccab.asp>. Acesso em: 17 mar. 2006.

COMPANHIA DE SANEAMENTO BÁSICO DO ESTADO DE SÃO PAULO. Concessionária de serviços sanitários. Disponível em:

<http://www.sabesp.com.br>. Acesso em: 22 nov. 2005. 
CROOK, J. Critérios de qualidade para água de reúso Tradução de: Hilton Felício dos Santos. Revista DAE, São Paulo, CETESB v., 174., p. 10-18, 1994.

CROSBY, P. B. Qualidade é investimento: a arte de garantir a qualidade. 2. ed. Rio de Janeiro: José Olympio, 1986. 327 p.

Qualidade, falando sério. São Paulo: McGraw-Hill, 1990. 201 p.

CYSNE, R.; SCHARAN, S. Organizando sua empresa visando as normas ISO 9000. São Paulo: Dempi, 1993.

DEMING, W. E. Qualidade: a revolução da administração. Rio de Janeiro: Marques Saraiva, 1990. 367 p.

DI BERNARDO, L.; DANTAS, A. D. B. Métodos e técnicas de tratamento de água. 2 ed. São Carlos: RiMa, 2005. v.1.

FEIGENBAUM, A. V Controle da qualidade total. São Paulo: Makron Books, 1994. v. 1.

FIGUEIREDO, V. V. F. de. Implantação do HACCP na industria de alimentos. Gestão e Produção, São Carlos, v. 8, n. 1, p.100-111, 2001.

FINK, D. R.; SANTOS, H. F. A legislação de reúso de água. In: MANCUSO, P. C. S.; SANTOS, H. F. (Ed.). Reúso de água. São Paulo: Manole, 2003. 119-122 p.

GARVIN, D. A. Gerenciando a qualidade: a visão estratégica e competitiva. Rio de Janeiro: Qualitymark, 1992. 357 p.

HESPANHOL, I. Potencial de reúso de água no Brasil: agricultura, indústria, municípios, recarga de aqüíferos. Revista Brasileira de Recursos Hídricos, v. 7, n.4, p. 75-95, out./dez. 2002.

; GONÇALVES, O. Manual de conservação e reúso de água para a indústria. São Paulo: FIESP/CIESP, 2005. 92 p.

JURAN, J. M. A qualidade desde o projeto: novos passos para o planejamento da qualidade em produtos e serviços. São Paulo: Pioneira, 1992. 

1992. v.3.

; GRYNA, F. M. Controle da qualidade. 4. ed. Rio de Janeiro: Makron,

LAVRADOR FILHO, J. Contribuição para o entendimento do Reúso planejado das águas e algumas considerações sobre suas possibilidades no Brasil. 1987. 198 f. Dissertação (Mestrado) - Escola Politécnica, Universidade de São Paulo, São Paulo, 1987.

MANCUSO, P. C. Reúso de água para torres de resfriamento. São Paulo: FSP/USP, 2001. 18 p. .; SANTOS, H. F. Reúso de água. São Paulo: Manole, 2003. 579 p.

MARANHÃO, M. ISO Série 9000: manual de implementação. Rio de Janeiro: Qualitymark, 2001. 220 p.

MENDONÇA, P. A. Reúso de águas em edifícios públicos: o caso da Escola Politécnica. 2004. 164 p. Dissertação (Mestrado) - Escola Politécnica, Universidade Federal da Bahia, Salvador, 2004.

METCALF \& EDDY. Wastewater engineering: treatment and reuse. Boston; London. McGraw-Hill, c2003. XXVIII, 1819 p. (McGraw-Hill series in civil and environmental engineering).

MIERZWA, J.C; HESPANHOL, I. Programa para o gerenciamento de água e efluentes nas indústrias visando o uso racional e o reúso. Engenharia Sanitária e Ambiental, Rio de Janeiro, v. 4, n. 1/2, p/11-15, Jan./Jun. 2002.

OLIVEIRA, R. Aproveitamento de águas pluviais para uso não potável. 2002. 68 f. Monografia (MBA em Sistema de Gestão Ambiental) - Pontifícia Universidade Católica do Paraná, Curitiba, 2002.

PALUDETTO, J. O. Reúso de água na indústria de curtimento de couros: estudo de caso no distrito industrial de Franca - SP. 2002. 105 p. Dissertação (Mestrado) - Escola Politécnica, Universidade de São Paulo, São Paulo, 2002.

PURI, S. C. ISO 9000 certificação: gestão da qualidade total. Rio de Janeiro: Qualitymark, 1994. 249 p. 
SANTOS, D. C. Os sistemas prediais e a promoção da sustentabilidade ambiental. Revista da Associação Nacional de Tecnologia do Ambiente Construído, Porto Alegre, v..2, p. 7-18, 2002.

SANTOS, P.A. Implementação de modelo de sistema da qualidade em uma empresa de reboque: avaliação dos resultados. 2002. 120 p. Dissertação (Mestrado) - Universidade de Taubaté, Taubaté, 2002.

SAUTCHUK, C. A. Formulação de diretrizes para implantação de programas de conservação de águas em edificações. 2004. 332 f. Dissertação (Mestrado) Escola Politécnica, Universidade de São Paulo, São Paulo, 2004.

SAUTCHUK, C. (Coord.) et al.; PIO, A. A. B. et al. Conservação e reúso da água em edificações. São Paulo: Agência Nacional de Águas, 2005. 151 p.

SCHVARTSMAN, S. Aditivos alimentares. Pediatria, São Paulo, v. 4, p. 202-210, mar. 1982.

SHREVE, R N; BRINK JR, J. A. Indústrias de processos químicos. 4. ed. Rio de Janeiro: Guanabara Dois, 1980. 717 p.

SILVA, A. C. P. et al. Reúso de água e suas implicações jurídicas. São Paulo: Navegar Editora, 2003. 111 p.

SPERBER, W. Auditing and verification of food safety and HACCP. Food Control, v.9, 1998..p 157-162

SPEXOTO, A. A. Aplicação do sistema de análise de perigos e pontos críticos de controle (APPCC) em propriedades leiteiras. 2003. 157 f. Dissertação (Mestrado), Universidade de São Paulo, Pirassununga, 2003.

TOMAZ, P. Economia de água para empresas e residências: um estudo atualizado sobre uso racional da água, v. 2. São Paulo. Navegar Editora; 2002. 250 p.

VIALTA, A.; MORENO, I.; VALLE, J. L. Boas práticas de fabricação, higienização eanálise de perigos e pontos críticos de controle na indústria de laticínios, Revista Indústria de Laticínios. v 6, n. 35. p. 56 - 63, jan/fev, 2002. 
WURLITTZER, N. D. Industrialização de alimentos visando a saúde do consumidor. Rio de Janeiro: SENAI; Centro de Tecnologia de Alimentos e Bebidas. Disponível em:

<http://www.firjan.org.br/notas/media/Alimentos.pdf>. Acesso em: 11 ago. 2006.

WESTERHOFF, G. P. An update of research needs for water reuse. In: WATER REUSE SYMPOSIUM, $3^{\circ}$ Proceedings. San Diego, Califórnia, 1984. p 1731-1742. 